U. S. DEPARTMENT OF AGRICULTURE, BUREAU OF STATISTICS-BULLETIN 102.

VICTOR H. OLMSTED, Chief of Bureau.

\title{
LIST OF AGRICULTURAL FAIRS AND EXHIBITIONS IN THE UNITED STATES.
}

BY

GEORGE K. HOLMES,

Chief of Division of Production and Distribution.

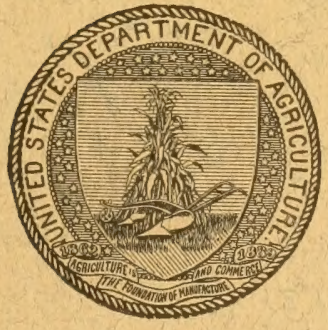

WASHINGTON:

GOVERNMENT PRINTING OFEIOE.

1913. 


\section{ORGANIZATION OF BUREAU OF STATISTICS.}

Statistician and Chief: Victor H. OLmSted.

Associate Statistician: NAT C. MurRay.

Assistant Statistician: SAmuel A. Jones.

Chief Clerk: Frank G. Kelsey.

Division of Domestic Crop Reports: Fred J. BLAIR, Statistical Scientist in Charge.

Division of Production and Distribution: GEORGE K. Holmes, Statistical Scientist in Charge.

Division of Research and Reference: CharLes M. DAugherty, Statistical Scientist in Charge.

Crop Reporting Board:

Victor H. Olmsted, Chairman; Nat C. Murray, George K. Holmes; one or more persons called in from the corps of special field agents and State statistical agents. 
U. S. DEPARTMENT OF AGRICULTURE, BUREAU OF STATISTICS-BULLETIN 102.

vICTOR H. OLMSTED, Chief of Bureau.

\section{LIST OF AGRICULTURAL FAIRS AND EXHIBITIONS IN THE UNITED STATES.}

GEORGE K. HOLMES,

Chief of Division of Production and Distribution.

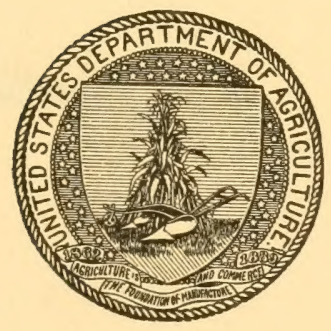

WASHINGTON:

GOVERNMENT PRINTTNG OFFICE.

1913. 


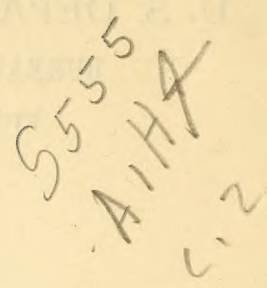

D. OF D.

FEB 211913 


\section{LETTER OF TRANSMITTAL.}

U. S. Department of Agriculture,

Bureau of Statistics,

Washington, D. C., June 30, 1912.

SIR: So frequent are the demands for a list of the agricultural fairs of this country that this bureau feels more than justified in offering the accompanying compilation for publication. The labor and expense required were not excessive and the list, subject to revision every few years, will doubtless constitute a permanent publication of the department.

It is respectfully recommended that it be published as Bulletin 102 of this bureau.

Very respectfully,

Hon. James Wilson,

Victor H. Olmsted, Chief of Bureau.

Secretary of Agriculture. 



\section{O N T E N TS.}

Brief history

Ancient origin ............................................. 7

Beginnings in the United States. .......................... 7

At Washington, D. C . . . . . . . . . . . . . . . . . . . . . . . 7

"Sheep shearings" at "Arlington," Va..................... 8

Columbian Agricultural Society, Washington, D. C . . . . . . . . . 9

Berkshire Agricultural Society, Pittsfield, Mass................. 11

Movement away from educational purposes.................... 11

Number of agricultural fairs and exhibitions.................... 12

Geographic distribution................................... 12

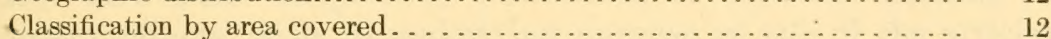

Classification by kind of exhibit. ............................ 12

Percentage tables...................................... 12

TABLE 1.-Number of fairs and exhibitions devoted to agriculture, live stock, and related subjects, 1912, by States and geo-

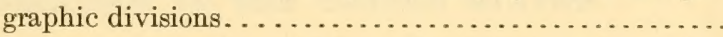

2.-Percentage of number of fairs and exhibitions devoted to agriculture, live stock, and related subjects, 1912, classified by area and kind of exhibit, by geographic divisions.

3.-Percentage of number of fairs and exhibitions devoted to agriculture, live stock, and related subjects, 1912, in each geographic division..........................

4.- - List of fairs and exhibitions devoted to agriculture, live stock, and other related subjects, by States, $1912 \ldots . .$. 


\section{LIST OF AGRICULTURAL FAIRS AND EXHIBITIONS IN THE UNITFD STATES.}

\section{BRIEF HISTORY.}

\section{ANCIENT ORIGIN.}

The agricultural fair of the United States, generally exemplified by the county fair, had its remote origin in the temporary assemblages of traders or producers in the ancient world for the purpose of selling their wares to the customers who assembled to meet them. Many of these fairs of the ancient pattern are found in Europe and Asia, somewhat changed, perhaps, from their original nature, but yet remaining fairs for purchase and sale.

In the course of time the ancient fair was changed into a fair at which there were competitive exhibitions of domestic animals or various products, with an underlying purpose of sale of the articles exhibited and particularly the more excellent ones. This has especially been the case with live-stock "shows" in England.

\section{BEGINNINGS IN THE UNITED STATES.}

The agricultural fair began in this country fully divorced from commercialism. It was purely educational in its purpose and was intended to stimulate farmers to improve their live stock, their domestic manufactures, and their agriculture. Several prominent agricultural associations were established in the eighteenth century for educational purposes, but without holding fairs or exhibitions. The fair had an interesting origin early in the nineteenth century.

\section{AT WASHINGTON, D. C.}

The agricultural fair of the United States had its inception in the District of Columbia. In 1804 it was suggested by Dr. Thornton, the first Commissioner of Patents, that the ready sale of cattle and domestic products in the National Capital could be promoted by the holding of fairs or market days, as in England, his native land. The idea met with warm approval on the part of the citizens, and the municipal authorities passed an act establishing semiannual fairs. An editorial article in the National Intelligencer of October 17, 1804, 
spoke of the coming fair as offering advantages to purchasers and to settlers, "while at the same time it could but prove equally beneficial to the agricultural interests of our country."

The fair was held on Wednesday, Thursday, and Friday, "on the Mall on the south side of the Tiber, extending from the bridge at the Center Market to the Potomac." "It was a decided success," and before the next one was held an attempt was made by additional legislation on the part of the city government to increase its usefulness by appropriating $\$ 50$ toward a fund for premiums. The citizens raised by subscription an equal sum, so that at the fair which began on April 26,1805, "premiums to the amount of $\$ 100$ were awarded to the best lamb, sheep, steer, milch cow, jack, oxen, and horse actually sold." A third fair was held in November, 1805, after which these market fairs were discontinued.

$$
\text { "SHEEP SHEARINGS" AT "ARLINGTON," VA. }
$$

More closely related to the inception of the fair movement in this country were the annual "sheep shearings" established and continued for a dozen years by George Washington Parke Custis, at "Arlington," his estate opposite Washington, D. C., on the Virginia side of the Potomac.

In 1866, Ben: Perley Poore, a noted writer of that time, in writing of these sheep shearings, comments that "those associated with him [Mr. Custis] in after life in the United States Agricultural Society will not wonder that large collections of prominent men used to accept his hospitable invitation to be present at these gatherings, where he entertained his guests beneath the marquee used throughout the Revolution by his illustrious guardian, George Washington." A program of one of these rural festivals, as published in a Georgetown newspaper of the day, follows:

Premiums at Arlington on the 30th of April, 1809.

SHEEP.

For the best tup-lamb, of 1 year, a silver cup; value, $\$ 60$.

For the best pair of ewes, of same age, a silver cup; value, $\$ 40$.

PRINCIPLE ESTABLISHED.

To the sheep which shall possess the best form, and yield the most and best wool in proportion to its size, the premium will be adjudged.

To the man (being a native American) who shall clip a fleece in the shortest time and best style, by clipping after the English fashion, $\$ 5$.

MANUFACTURES.

For the national military dress, or uniform of Morgan's riflemen, with a complete statement of the exnense accompanying the same, $\$ 20$. 
For the best 5 yards of cloth, yard wide, and composed of cotton and silk-the silk to be derived from articles which have been worn out, as gloves, umbrellas, etc. $-\$ 15$.

For the best blanket of common size, $\$ 10$.

For the best 5 yards of flannel, to be all wool, $\$ 10$.

For the best ball of wool yarn, weighing 1 pound, which shall be spun to the greatest fineness on a wheel, to be ascertained by weighing any 10 yards in the ball, $\$ 5$.

To that family, in the county of Alexandria, who shall make it appear that they have made the greatest quantity of wearing apparel of domestic manufactures, and used the least of foreign importations, the largest prize fleece.

To that family, in said county, who shall prove that to a given number of female children, the most are good spinners, the next largest fleece.

To the cultivator of the soil, in said county, who shall prove that he has manured most land from his own resources, in the last 12 months, toll free at the Washington Mills for one year.

Washington, November 20, 1808 .

It is very probable that the "sheep shearings" at "Arlington" were the germ of the first agricultural fair in this country, organized in 1809 , when its first fair was held.

\section{COLUMBIAN AGRICULTURAL SOCIETY, WASHINGTON, D. C.}

In 1809 a number of gentlemen interested in agriculture, residing in Maryland, Virginia, and the District of Columbia, after several meetings, organized the Columbian Agricultural Society. The first exhibition was held at the Union Hotel, Georgetown, on the 10th of May. It was (said the National Intelligencer of the following Friday) "attended by a numerous assemblage of members of the society, among whom we noticed the President and his lady, the Secretary of State, the Secretary of the Treasury, the Secretary of War, the comptroller, register, etc., and many other ladies and gentlemen of respectability. This is the first exhibition held by the society, which bids fair to exceed anything of the kind in the United States, and promises to be of great utility in the promotion of the agricultural arts, and particularly of the domestic manufactures of cotton, wool, and flax, by exciting a competition which can not but be productive of good effects.

"There were exhibited a great number of sheep of the best breeds, among which were several half and three-quarter breed merinos. At half past 11 o'clock the room for the exhibition of domestic fabrics was thrown open, when many specimens were displayed highly honorable to the industry and ingemuity of those who produced them, and gratifying to those who have at heart the cultivation of the resources of the country. Some specimens of diaper, bed ticking, and cotton bagging were particularly admired as equal to any imported. The result of the day was highly pleasing to all concerned; and the auspicious commencement of this patriotic $64267^{\circ}-13-2$ 
institution furnishes another, in addition to the many evidences already existing, of the public spirit of the District."

The second exhibition of this society was held in what was then known as Parrott's grove, on the heights of Georgetown. The National Intelligencer of November 22, 1809, says of it: "The second semiannual exhibition of the Columbian Agricultural Society was held at Georgetown yesterday. A large concourse of members and visitors, with their ladies and families, were present. Among the visitors were the President and family, the Postmaster General, the treasurer, the auditor, the Russian minister, mayor, Mr. Barlow, Mr. Irving, and many other ladies and gentlemen of respectability. Owing to the late inclemency of the season, but few cattle were exhibited; but, to compensate for this defieiency, there was a great quantity of cotton and woolen domestic fabrics, comprehending much good cloth, blanketing, carpeting, hosiery, and so forth. The blanketing appeared to be most admired, though much praise was given to several pieces of cloth and carpeting."

The third semiannual exhibition of this society was held May 16, 1811, in Parrott's grove, and in its report of the exhibition the National Intelligencer of the next day says: "It was attended, as usual, by several hundred of the most respectable ladies and gentlemen in the District and neighboring counties of Virginia and Maryland, among whom were the President, heads of departments, and generally all the prominent officers of the Government, the French minister, and our minister to France. The show of sheep-merino, mixed blood, and natives - was said to be as numerous and respectable as any ever seen in the country. The manufactures, exclusively domestic, attracted much attention. The premiums were distributed as awarded by the judges. The pleasantness of the day, the nature of the ground, shaded with forest trees; the fragrance of the flowers, with the various entrances to the inclosure decorated, the presence of the music, and the good humor and gaiety which it contributed to diffuse, rendered the meeting unusually agreeable."

On November 20, 1811, the fourth semiannual exhibition of this society was held in Georgetown, and was fully reported in the National Intelligencer. The following is an extract from the report: "The day was rainy, and therefore unfavorable to the exhibition, especially of cattle. Of above 100 that had been brought into the town and neighborhood, not more than 6 or 8 were exhibited, the state of the weather rendered it so inconvenient. The cattle exhibited attracted general notice, especially an extraordinary steer, raised by Mr. Steinberger, of Shenandoah County, Va. This animal is believed to be the largest ever raised in Virginia; it is supposed he will weigh 2,700 pounds on the hoof and near 2,000 pounds net beef. 
The show of domestic manufactures could not but be pleasing to every person present. The specimens of woolen cloth, blankets, flannels, kerseymeres, carpets, fancy patterns, cotton cloths, etc., evinced the progress which our citizens are making in this branch of economy. Many of the articles were judged to be equal, some were thought superior, to imported fabrics of the same kind."

The fifth semiannual exhibition of the Columbian Agricultural Society was held in Georgetown, May 20,1812, and the sixth one was held November 18 in the same year. Unfortunately the war with England overshadowed everything else and, as the time had expired for which the society had been organized, it was dissolved.

BERKSHIRE AGRICULTURAL SOCIETY, PITTSFIELD, MASS.

It has generally been believed that the first agricultural fair in this country was that of the Berkshire Agricultural Society at Pittsfield, Mass., in 1810. The fact remains, however, that the Berkshire Agricultural Society held its first fair before any other present-existing agricultural society.

\section{CHANGES IN CHARACTER OF FAIRS.}

\section{MOVEMEINT AWAY FROM EDUCATIONAL PURPOSES.}

In the course of time the educational features of the agricultural fair in this country were compelled to admit the attraction of horse racing, and eventually, so prominent did horse racing become, that much opposition was developed, and the opposition was not entirely to gambling on the races. Racing, however, was not suppressed, and it is still a prominent feature of agricultural fairs.

Another intrusion into the educational purposes of the fair, becoming prominent long after horse racing had become so, was composed of shows in small tents, open-air exhibits for amusement or excitement, various gambling games, among which, at one time, was the "shell game," and numerous devices of "fakirs" to amuse and excite, if not fleece, the attendants at the fairs.

These features of the agricultural fair, in the course of time, dominated the educational features in many instances, and it is only in recent years that efforts have been made to reduce these distractions and restore the agricultural fair largely to its original purpose.

A difficulty that the managing fair committee has had to face has been, as it still is, the raising of sufficient income to pay premiums and other expenses. Partly for this reason fair managers have made the most of their opportunitics to provide amusements for the purpose of raising revenue, and, in the case of many fairs, they have not refrained from pursuing this policy to the limit. 


\section{NUMBER OF AGRICULTURAL FAIRS AND EXHIBITIONS.}

\section{GEOGRAPHIC DISTRIBUTION.}

The societies that hold regular fairs and exhibitions, in the list following, have been classified and counted, with results that may be found in the accompanying table. It appears in this table that the total number of fairs in the list is 2,740. Among the geographic divisions, the largest number, 764 , is found in the East North Central group of States, and the West North ('entral group of States follows in order with 573 societies. Third in order is the Middle Atlantic group of States with 372 societies; fourth, New England, with 229 societies; fifth, South Atlantic, with 211 societies, after which follow the East South Central States, with 198 societies; the Pacific States, with 146; the West South Central States, with 140; and the Mountain States, with 107 societies.

\section{CLASSIFICATION BY AREA COVERED.}

In asking the societies to supply the facts required for this list, they were requested to specify their geographic scope, and the answers have been tabulated as given. The various totals of the reports place the number of societies holding international fairs and exhibitions at 102; the national ones at 129; the interstate ones at 200 ; the State ones at 155 ; the intercounty at 466 ; county, 839 ; local, 250; and still there remain 599 for which no report was obtained.

\section{CLASSIFICATION BY KIND OF EXHIBIT.}

The associations in this list have been classified according to the kind of their exhibit. Those that hold fairs or exhibitions devoted to general agriculture number 1,647; horticulture, 80; floriculture, 13; corn, 4 ; live stock, 22 ; horses, 81 ; poultry, 685 ; poultry and pigeons, 19 ; poultry and pet stock, 86 ; poultry, pigeons, and pet stock, 21; dogs, 74 ; apiculture, 1 ; and dairy products, 7 .

\section{PERCENTAGE TABLES.}

The numbers of the associations, classified according to the geographic scope of their fairs and exhibitions and also according to the kind of exhibit, have been converted into percentages, which may be found in the accompanying tables. 
TABLE 1.-Number of fairs and exhibitions devoted to agriculture, live stock, and related subjects, 1912, by States and geographic divisions.

\section{CLASSIFICATION BY AREA.}

\begin{tabular}{|c|c|c|c|c|c|c|c|c|c|}
\hline State and geographic division. & Total. & $\begin{array}{c}\text { In- } \\
\text { ter- } \\
\text { na- } \\
\text { tion- } \\
\text { al. }\end{array}$ & $\begin{array}{c}\mathrm{Na}- \\
\text { tion- } \\
\text { al. }\end{array}$ & $\begin{array}{l}\text { Inter- } \\
\text { state. }\end{array}$ & State. & $\begin{array}{l}\text { Inter- } \\
\text { county. }\end{array}$ & County. & Local. & $\begin{array}{l}\text { Not re } \\
\text { ported. }\end{array}$ \\
\hline Maine. & 60 & 1 & 1 & 1 & 7 & 5 & 16 & 15 & 14 \\
\hline New Hampshire................ & 14 & 3 & 1 & $\ldots$ & 1 & 2 & & 1 & 6 \\
\hline 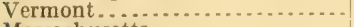 & 25 & 1 & 3 & & 3 & 2 & 9 & 3 & 4 \\
\hline 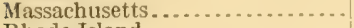 & 59 & 4 & 8 & 7 & & 7 & 16 & 12 & 5 \\
\hline Rhode Island................... & 10 & 2 & 2 & 2 & 1 & & 1 & & 2 \\
\hline Connecticut.................... & 61 & 2 & 4 & 5 & 5 & 8 & 6 & 16 & 15 \\
\hline 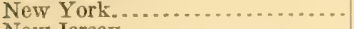 & $\begin{array}{r}161 \\
28\end{array}$ & 20 & 10 & 11 & 6 & 27 & 44 & 22 & 21 \\
\hline New Jersey ............................. & 38 & 1 & 9 & 10 & & 2 & 4 & 2 & 10 \\
\hline 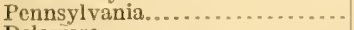 & 173 & 9 & 13 & 15 & 8 & $2 \overline{2}$ & 54 & 20 & 32 \\
\hline Delaware ........................ & 6 & 1 & 1 & 1 & 2 & & & & 1 \\
\hline 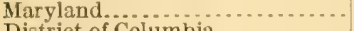 & 19 & 1 & i & 4 & 3 & 3 & 4 & $\cdots \cdot$ & 4 \\
\hline District of Columbia.............. & 4 & 1 & 1 & & & & & & \\
\hline 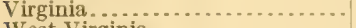 & 47 & 4 & 2 & 4 & 2 & 11 & 9 & 6 & 9 \\
\hline a................... & 31 & $\cdots$ & 2 & 6 & 3 & 5 & 10 & & 5 \\
\hline North Carolina....................... & 30 & & 2 & 3 & 2 & 7 & 4 & & 12 \\
\hline South Carolina ................... & 31 & - & 1 & 3 & & 4 & 10 & 1 & 12 \\
\hline 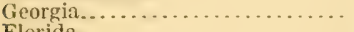 & 28 & 1 & 2 & 3 & 1 & 4 & 6 & & 11 \\
\hline Florida......... & 15 & & & 2 & 3 & 1 & 2 & & 7 \\
\hline Ohio $\ldots \ldots \ldots \ldots \ldots \ldots \ldots \ldots \ldots$ & 195 & 9 & 13 & 15 & 12 & 31 & 57 & 30 & 28 \\
\hline 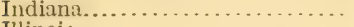 & 131 & 2 & 7 & 13 & 4 & 34 & 34 & 8 & 29 \\
\hline . $\ldots \ldots \ldots \ldots \ldots \ldots \ldots \ldots \ldots$ & 202 & 4 & 9 & 15 & 7 & 35 & 53 & 24 & 55 \\
\hline 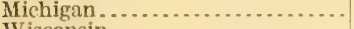 & 112 & 3 & 4 & 5 & 8 & 20 & 33 & 7 & 32 \\
\hline 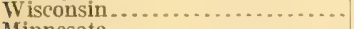 & 124 & 4 & 2 & 8 & 11 & 21 & 44 & 13 & 21 \\
\hline Minnesota....................... & 83 & & 2 & 4 & 1 & 20 & 43 & 3 & 10 \\
\hline 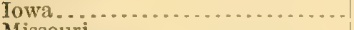 & 188 & 4 & 3 & 10) & 4 & 47 & 69 & 14 & 37 \\
\hline Missouri. & 137 & 5 & 6 & 5 & 4 & 27 & 45 & 9 & 36 \\
\hline North Dakota... & 26 & 1 & $\cdots$ & 2 & 3 & 4 & 11 & 1 & 4 \\
\hline South Dakota....................... & 27 & 1 & & 1 & 2 & 1 & 15 & 1 & 6 \\
\hline 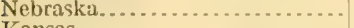 & 28 & …... & 1 & 2 & 4 & 1 & 11 & 2 & 7 \\
\hline 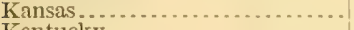 & 84 & -...... & 3 & 3 & 4 & 19 & 29 & 8 & 18 \\
\hline бу $\ldots \ldots \ldots \ldots \ldots \ldots \ldots \ldots$ & 75 & - & 2 & 1 & 2 & 11 & 40 & 2 & 19 \\
\hline 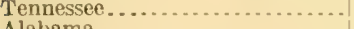 & 51 & 1 & 3 & 2 & 2 & 11 & 21 & 1 & 10 \\
\hline a $\ldots \ldots \ldots \ldots \ldots . . . . . . . . .$. & 21 & 2 & $\because$ & $\because$ & 3 & 2 & 10 & ... & 4 \\
\hline 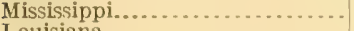 & 34 & -....... & 1 & 5 & 2 & 7 & 12 & $\because$ & 7 \\
\hline Louisiana........ . & 17 & (n) & $\begin{array}{l}1 \\
3\end{array}$ & 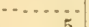 & $\frac{1}{4}$ & 1 & 7 & & ó \\
\hline 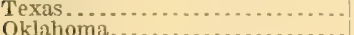 & 58 & $\begin{array}{l}2 \\
2\end{array}$ & $\begin{array}{l}3 \\
2\end{array}$ & $\begin{array}{l}5 \\
4\end{array}$ & $\begin{array}{l}4 \\
3\end{array}$ & 9 & 11 & 4 & $\begin{array}{l}20 \\
18\end{array}$ \\
\hline (2, & $\begin{array}{l}61 \\
21\end{array}$ & & $\begin{array}{l}2 \\
2\end{array}$ & 1 & $\begin{array}{l}3 \\
1\end{array}$ & 6 & $\begin{array}{r}19 \\
4\end{array}$ & 6 & $\begin{aligned} 18 \\
6\end{aligned}$ \\
\hline (1) & 21 & & & 1 & 4 & $\begin{array}{l}6 \\
5\end{array}$ & $\begin{array}{r}4 \\
13\end{array}$ & $\begin{array}{l}1 \\
2\end{array}$ & 5 \\
\hline (n) & 6 & & 1 & & 1 & i & $\begin{array}{r}13 \\
3\end{array}$ & $\begin{array}{c}2 \\
\ldots\end{array}$ & \\
\hline Colorado........ & 32 & 1 & 3 & 1 & 2 & 7 & 13 & 2 & 3 \\
\hline New Mexico..... & 23 & & & & 1 & 2 & 7 & 1 & 12 \\
\hline Arizona......... & 5 & & & 1 & & 2 & & & 2 \\
\hline Utah ................. & $\begin{array}{l}30 \\
?\end{array}$ & 2 & & . & 2 & $\ldots$ & 4 & $\cdots$ & 2 \\
\hline da.......... & 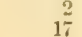 & 1 & & & 1 & & & & \\
\hline hington. & $\begin{array}{l}17 \\
42\end{array}$ & & & 4 & 3 & 2 & 5 & $\cdots$ & 3 \\
\hline hington.... & $\begin{array}{l}42 \\
30\end{array}$ & 4 & $\cdots$ & 5 & 2 & 8 & 9 & 5 & $\begin{array}{l}9 \\
5\end{array}$ \\
\hline $\begin{array}{l}\text { Oregon } . . . . . . . . . . \\
\text { California........ }\end{array}$ & 50 & 3 & $i$ & $\begin{array}{l}6 \\
6\end{array}$ & 9 & 7 & 11 & & 12 \\
\hline Cahlornia........ & & & & & & 7 & 11 & 8 & 12 \\
\hline $\begin{array}{l}\text { Geographic division: } \\
\text { New England...... }\end{array}$ & & & & & & & & & \\
\hline $\begin{array}{l}\text { New England...... } \\
\text { Middle Atlantic.... }\end{array}$ & $\begin{array}{l}229 \\
372\end{array}$ & $\begin{array}{l}13 \\
30\end{array}$ & 19 & 15 & 17 & 24 & 48 & 47 & 46 \\
\hline $\begin{array}{l}\text { Middle Atlan } \\
\text { South Atlant }\end{array}$ & 372 & 30 & 32 & 36 & 14 & 51 & 102 & 44 & 63 \\
\hline $\begin{array}{l}\text { Sou } \\
\text { Eas }\end{array}$ & 211 & 8 & 11 & 26 & & 35 & 45 & 7 & (6) \\
\hline East & 764 & 22 & 35 & 56 & 4 & 141 & 221 & 82 & 165 \\
\hline West North Ce & 573 & 11 & 15 & 27 & 22 & 119 & 223 & 38 & 118 \\
\hline East South Cer & 181 & 3 & 4 & 8 & 9 & 31 & 83 & 3 & 40 \\
\hline West Sou & 157 & 4 & 8 & 10 & 9 & 23 & 41 & 11 & 51 \\
\hline Mountain..... . . & 124 & 4 & 4 & 6 & 14 & 19 & 45 & 5 & 27 \\
\hline Pacific......... & 129 & 7 & 1 & 17 & 12 & 22 & 31 & 13 & 26 \\
\hline United States............. & 2,740 & 102 & 129 & 200 & 155 & 466 & 839 & 250 & 599 \\
\hline
\end{tabular}


TABLE 1.-Number of fairs and exhibitions devoted to agriculture, live stock, and related subjects, 1912, by States and geographic divisions-Continued.

KIND OF EXHIBIT.

\begin{tabular}{|c|c|c|c|c|c|c|c|c|c|c|c|c|c|}
\hline State and geographic division. & 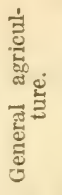 & 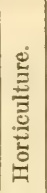 & 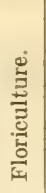 & 릉 & $\begin{array}{l}\text { है } \\
\text { हु } \\
\text { है } \\
0 \\
\stackrel{8}{3}\end{array}$ & 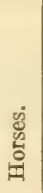 & 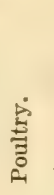 & 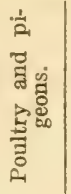 & 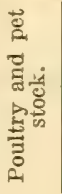 & 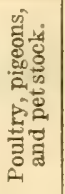 & $\begin{array}{l}\dot{0} \\
\text { to } \\
\stackrel{0}{0}\end{array}$ & 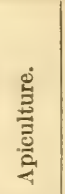 & 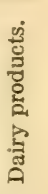 \\
\hline Iaine. & 53 & 1 & & & & 1 & 5 & & & & & & \\
\hline $\begin{array}{l}\text { New Hamp } \\
\text { Vermont.. }\end{array}$ & 8 & 1 & & & & & 5 & & & & & & \\
\hline $\begin{array}{l}\text { Vermont.... } \\
\text { Massachuset }\end{array}$ & $\begin{array}{l}18 \\
32\end{array}$ & $\begin{array}{l}1 \\
6\end{array}$ & & & & $\begin{array}{c}1 \\
\ldots\end{array}$ & $\begin{array}{l}4 \\
9\end{array}$ & 1 & 1 & 1 & 9 & & \\
\hline$\ldots \ldots \ldots \ldots \ldots$ & 3 & 1 & & & 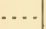 & 1 & 4 & & & & 1 & & \\
\hline Connecticut... & 40 & 6 & 1 & & $\ldots$ & $\cdots$ & 8 & $\cdots$ & 2 & 2 & & 1 & 1 \\
\hline$\ldots \ldots \ldots \ldots$ & 100 & 9 & 4 & & $\cdots$ & 7 & 21 & 3 & 7 & 1 & 9 & ...... & … \\
\hline$\ldots \ldots \ldots \ldots \ldots \ldots$ & 7 & 3 & $\cdots$ & & & 9 & 8 & 3 & & 3 & $\begin{array}{l}5 \\
0\end{array}$ & …. & $\cdots$ \\
\hline bia.................. & 86 & 8 & $\cdots$ & $\cdots$ & 3 & & 41 & 6 & 14 & 4 & 9 & $\ldots$ & $\cdots$ \\
\hline $\begin{array}{l}\text { Delaware } \ldots \ldots \ldots \ldots \ldots \\
\text { Maryland } . . . \ldots \ldots \ldots \\
\end{array}$ & ${ }_{12}^{2}$ & $\begin{array}{l}1 \\
1\end{array}$ & $\cdots$ & & $\cdots$. & $\begin{array}{l}1 \\
3\end{array}$ & i & $\begin{array}{l}1 \\
2\end{array}$ & & & 1 & & $\begin{array}{l}\cdots \\
\cdots\end{array}$ \\
\hline District of Columbia............ & & 1 & & & & 1 & & 1 & & & i & $\cdots$ & $\cdots$ \\
\hline Virginia....$\ldots \ldots \ldots \ldots \ldots \ldots \ldots$ & 24 & 1 & & & & 13 & 8 & & & & 1 & - & ... \\
\hline $\ldots \ldots \ldots \ldots \ldots \ldots$, & 15 & 1 & .. & & 1 & 1 & 12 & & 1 & & & & $\cdots$ \\
\hline ….... & 17 & .. & & & & & 12 & & 1 & & $\cdots$ & $\cdots$ & $\cdots$ \\
\hline $\begin{array}{l}\ldots \ldots \ldots \ldots \ldots \\
\cdots \ldots \ldots \ldots \ldots \\
\cdots \ldots \ldots\end{array}$ & 24 & $\cdots$ & $\cdots$ & 1 & 1 & 2 & 3 & & & & $\cdots$ & $\ldots .$. & $\cdots$ \\
\hline 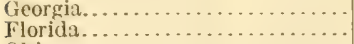 & 16 & $\begin{array}{l}1 \\
1\end{array}$ & 1 & & & $\cdots \cdot$ & $\begin{array}{r}10 \\
3\end{array}$ & -. & .... & $\cdots$ & -. & -..... & $\cdots$ \\
\hline 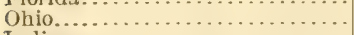 & 105 & 1 & $\ddot{i}$ & & $\ddot{i}$ & 3 & 64 & & 18 & & $\ddot{3}$ & $\ldots$ & $\because$ \\
\hline$\ldots \ldots$. & 63 & 1 & 1 & & & 5 & 49 & & 9 & i & 2 & $\ldots$ & \\
\hline$\ldots \ldots \ldots \ldots \ldots \ldots \ldots \ldots \ldots \ldots \ldots \ldots$ & 94 & 5 & 1 & 2 & 1 & 5 & 83 & & 7 & 1 & 2 & $\ldots$ & i \\
\hline$\ldots \ldots \ldots \ldots \ldots \ldots, \ldots$ & 68 & & & & 1 & & 38 & & 3 & $\ldots \ldots$ & 1 & ...... & 1 \\
\hline$\cdots \cdots \cdots \cdots$ & 83 & 1 & 1 & $\cdots$ & $\because$ & 1 & 31 & & 4 & ... & 1 & 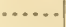 & 2 \\
\hline$\cdots \cdots$ & 65 & $\because$ & $\cdots$ & $\ldots$. & 1 & 1 & 15 & $\cdots \cdot$ & 1 & 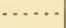 & & & \\
\hline (n. & 110 & 1 & $\cdots$ & & 1 & 6 & 59 & $\cdots \cdot$ & 8 & ...... & 2 & $\cdots$ & 1 \\
\hline (n) & $\begin{array}{l}83 \\
23\end{array}$ & 2 & $\cdots$ & 1 & 3 & 4 & $\begin{array}{r}40 \\
2\end{array}$ & $\mid \cdots \ldots$ & 1 & $\cdots$ & $\begin{array}{l}3 \\
1\end{array}$ & $\cdots \cdots \cdot$ & $\cdots$ \\
\hline 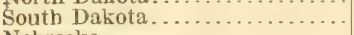 & 20 & 1 & & & $\cdots$ & $\begin{array}{l}\cdots \\
\cdots\end{array}$ & 5 & & & & 1 & $\begin{array}{l}\cdots \\
\ldots\end{array}$ & $\cdots$ \\
\hline Nebraska................... & 19 & $\cdots$ & .... & & 1 & ... & 6 & & 1 & & 1 & $\cdots \cdots$ & - \\
\hline 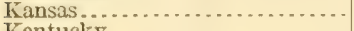 & 66 & & & & & 1 & 15 & 1 & 1 & & & $\ldots . .$. &. \\
\hline$y \quad \ldots \ldots \ldots \ldots \ldots \ldots$ & 64 & 1 & $\cdots$ & $\cdots$ & 2 & 2 & 5 & & & & 1 & ...... & . \\
\hline$\ldots \ldots \ldots$ & 39 & 1 & $\ldots$ & $\cdots$ & ... & .... & 9 & & & & 2 & .... & ... \\
\hline$\cdots$ & 18 & & & $\cdots$ & & & 3 & $\cdots$ & & & & ... & .. \\
\hline $\begin{array}{l}\text { pi....... } \\
\text { a........ }\end{array}$ & 26 & 1 & .. & $\ldots$ & $\ldots$ & 1 & $\begin{array}{l}6 \\
3\end{array}$ & $\cdots$ & & $\cdots$ & $\cdots$ & $\cdots$ & - \\
\hline$\cdots \cdots$ & 13 & $\cdots$ & & 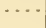 & & 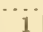 & 3 & & 1 & & & $\cdots$ & .... \\
\hline$\cdots \ldots \ldots \ldots \ldots \ldots \ldots$ & 23 & $\cdots$ & & $\ldots$ & $\frac{1}{1}$ & $\begin{array}{l}1 \\
1\end{array}$ & $\begin{array}{l}27 \\
10\end{array}$ & 1 & 2 & & 3 & & -. \\
\hline$\ldots \ldots \ldots \ldots \ldots \ldots \ldots \ldots \ldots$ & 14 & $\cdots$ & & & 1 & 11 & $\begin{array}{r}10 \\
5\end{array}$ & & & 1 & & & - \\
\hline$\cdots \cdots \cdots+$ & 22 & 2 & & & & 1 & 4 & & & & & ...... & $\cdots$ \\
\hline$\cdots$ & 6 & & & & & $\cdots$ & & & & & & & $\cdots$ \\
\hline 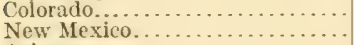 & 21 & 1 & $\cdots$ & & 1 & & 8 & & & & $i$ & ... & $\cdots$ \\
\hline xico $\ldots \ldots \ldots \ldots \ldots \ldots \ldots \ldots$ & 15 & 5 & $\cdots$ & $\ldots$ & 1 & 1. & 1 & .. & & & $\cdots$ & & - \\
\hline 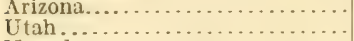 & $\begin{array}{l}3 \\
8\end{array}$ & $\cdots$ & .... & 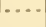 & $\ldots$. & 1 & 1 & …... & & & & …. & $\cdots$ \\
\hline$\cdots \cdots \cdots \cdots \cdots \cdots$ & $\begin{array}{l}8 \\
1\end{array}$ & $\cdots \cdot$ & $\cdots$ & $\cdots$ & $\cdots$ & $\cdots$ & 2 & $\cdots$ & $\cdots$ & & & .... & $\cdots$, \\
\hline (n. & 12 & $\begin{array}{l}\cdots \\
\ldots\end{array}$ & & & $i$ & $\cdots$ & $\begin{array}{l}1 \\
4\end{array}$ & & & & & . & $\cdots$ \\
\hline ............ & 16 & 2 & $i$ & $\cdots$ & & 2 & 16 & & & & & $\ldots$ & $\cdots$ \\
\hline$\ldots \ldots \ldots \ldots$ & 19 & 4 & & & 1 & 1 & 3 & & 1 & & $\begin{array}{l}4 \\
1\end{array}$ & .. & - \\
\hline Calilornia. & 18 & 8 & 2 & $\ldots$ & $\ldots$ & 1 & 16 & & 2 & 1 & 9 & & \\
\hline Geog & & & & & & & & & & & & & \\
\hline & 154 & 16 & 1 & & & 3 & 35 & 1 & 3 & 3 & 10 & 1 & 2 \\
\hline Middle Atlar & 193 & 20 & 4 & & 3 & 18 & 70 & 12 & 21 & 8 & 23 & $\ldots$ & $\ldots$ \\
\hline South Atla & 121 & $7 !$ & 1 & 1 & 2 & 21 & 49 & 4 & 2 & & 3 & ...... & \\
\hline East Nor & 413 & 7 & 4 & 2 & 3 & 14 & 265 & & 41 & 2 & 9 & $\cdots$ & \\
\hline West No & 386 & 4 & $\cdots$ & 1 & 6 & 12 & 142 & 1 & 12 & & 8 & $\ldots$ & 1 \\
\hline Eas & 147 & 3 & & $\ldots$ & 2 & 3 & 23 & & & & 3 & & $\cdots$ \\
\hline West South Central... & 92 & 1 & $\ldots$ & ... & 2 & 3 & 45 & 1 & 3 & 7 & 3 & & $\cdots$ \\
\hline Mountain........... & 88 & 8 & $\cdots$ & $\ldots$ & 3 & 3 & 21 & -. & & $\cdots$ & 14 & & $\cdots$ \\
\hline P'acific.... & 53 & 14 & 3 & & 1 & 4 & 35 & & 4 & 1 & 14 & & $\cdots$ \\
\hline United States. & 1,647 & 80 & 13 & 4 & 22 & 81 & 685 & 19 & 86 & 21 & 74 & 1 & 7 \\
\hline
\end{tabular}


TABLE 2.-Percentage of number of fairs and exhibitions devoted to agriculture, live stock, and related subjects, 1912, classified by area and kind of exhibit, by geographic divisions.

CLASSIFICATION BY AREA.

\begin{tabular}{|c|c|c|c|c|c|c|c|c|c|}
\hline Geographic division. & Total. & $\begin{array}{c}\text { Inter- } \\
\text { na- } \\
\text { tion- } \\
\text { al. }\end{array}$ & $\begin{array}{l}\text { Na- } \\
\text { tion- } \\
\text { al. }\end{array}$ & $\begin{array}{l}\text { Inter- } \\
\text { state. }\end{array}$ & State. & $\begin{array}{c}\text { Inter- } \\
\text { coun- } \\
\text { ty. }\end{array}$ & $\begin{array}{c}\text { Coun- } \\
\text { ty. }\end{array}$ & $\begin{array}{l}\text { Lo- } \\
\text { cal. }\end{array}$ & $\begin{array}{l}\text { Not } \\
\text { re- } \\
\text { port- } \\
\text { ed. }\end{array}$ \\
\hline 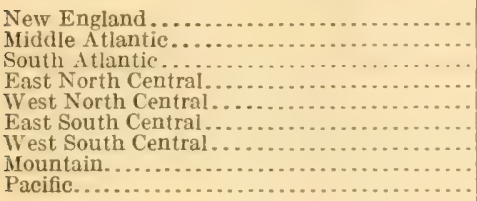 & $\begin{array}{l}100.0 \\
100.0 \\
100.0 \\
100.0 \\
100.0 \\
100.0 \\
100.0 \\
100.0 \\
100.0\end{array}$ & \begin{tabular}{l|}
5.7 \\
8.1 \\
3.8 \\
2.9 \\
1.9 \\
1.5 \\
2.9 \\
3.7 \\
4.8
\end{tabular} & $\begin{array}{l}8.3 \\
8.6 \\
5.2 \\
4.6 \\
2.6 \\
2.5 \\
5.0 \\
3.7 \\
.7\end{array}$ & $\begin{array}{r}6.5 \\
9.7 \\
12.3 \\
7.3 \\
4.7 \\
3.5 \\
7.1 \\
1.9 \\
14.4\end{array}$ & $\begin{array}{r}7.4 \\
3.8 \\
7.6 \\
5.5 \\
3.9 \\
5.1 \\
5.7 \\
10.3 \\
10.3\end{array}$ & $\begin{array}{l}10.5 \\
13.7 \\
16.6 \\
18.5 \\
20.8 \\
16.7 \\
15.7 \\
15.9 \\
16.4\end{array}$ & $\begin{array}{l}21.0 \\
27.4 \\
21.3 \\
28.9 \\
38.9 \\
45.5 \\
24.3 \\
37.4 \\
24.6\end{array}$ & $\begin{array}{r}20.5 \\
11.8 \\
3.3 \\
10.7 \\
6.6 \\
1.5 \\
7.9 \\
4.7 \\
8.9\end{array}$ & $\begin{array}{l}20.1 \\
16.9 \\
29.9 \\
21.6 \\
20.6 \\
23.7 \\
31.4 \\
22.4 \\
19.9\end{array}$ \\
\hline 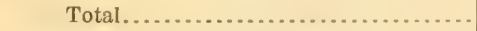 & 100.0 & 3.7 & 4.7 & 7.3 & 5.7 & 17.0 & 30.6 & 9.1 & 21.9 \\
\hline
\end{tabular}

KIND OF EXHIBIT.

\begin{tabular}{|c|c|c|c|c|c|c|c|c|c|c|c|c|c|c|}
\hline Geographic division. & 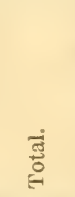 & 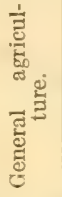 & 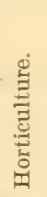 & 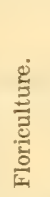 & ํํㅇ & 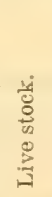 & 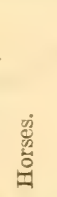 & 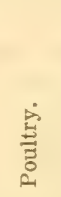 & 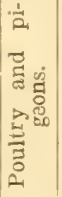 & 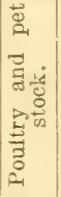 & 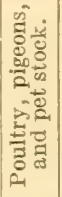 & $\begin{array}{l}\dot{\infty} \\
\stackrel{0}{0} \\
\stackrel{0}{0}\end{array}$ & $\frac{0}{\stackrel{0}{3}}$ & 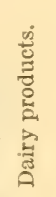 \\
\hline 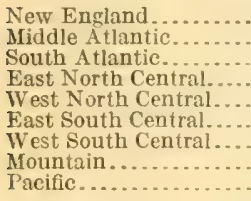 & $\begin{array}{l}100.0 \\
100.0 \\
100.0 \\
100.0 \\
100.0 \\
100.0 \\
100.0 \\
100.0 \\
100.0\end{array}$ & $\begin{array}{l}67.3 \\
51.9 \\
57.3 \\
54.0 \\
67.3 \\
80.8 \\
56.4 \\
71.0 \\
44.5\end{array}$ & $\begin{array}{r}7.0 \\
5.4 \\
3.3 \\
.9 \\
.7 \\
1.5 \\
7.7 \\
7.5\end{array}$ & $\begin{array}{r}0.4 \\
1.1 \\
.5 \\
.5 \\
. . .5 \\
. . .\end{array}$ & $\begin{array}{r}\ldots . . \\
0.3 \\
0.3 \\
.2 \\
\hdashline \ldots . . \\
\hdashline . .\end{array}$ & $\begin{array}{r}0.8 \\
1.0 \\
.4 \\
1.0 \\
1.0 \\
1.4 \\
1.9 \\
1.4\end{array}$ & $\begin{array}{r}1.3 \\
4.8 \\
10.0 \\
1.8 \\
2.1 \\
1.5 \\
2.2 \\
2.8 \\
2.7\end{array}$ & $\begin{array}{l}15.3 \\
18.8 \\
23.2 \\
34.7 \\
24.8 \\
13.2 \\
30.0 \\
15.9 \\
26.7\end{array}$ & $\begin{array}{c}0.4 \\
3.2 \\
1.9 \\
\ldots . . \\
.2 \\
\cdots .7 \\
\ldots . .\end{array}$ & $\left|\begin{array}{r}1.3 \\
5.6 \\
.9 \\
5.4 \\
2.1 \\
.5 \\
1.4 \\
\cdots \\
2.7\end{array}\right|$ & $\begin{array}{c}1.3 \\
2.2 \\
\ldots . . \\
.3 \\
\cdots . \\
\cdots \\
5.0 \\
\cdots .0 \\
.7\end{array}$ & $\begin{array}{r}4.4 \\
6.2 \\
1.4 \\
1.2 \\
1.4 \\
1.5 \\
2.2 \\
.9 \\
9.6\end{array}$ & $\begin{array}{c}0.4 \\
\ldots \ldots \\
\cdots \ldots \\
\cdots \ldots \\
\cdots \ldots \\
\cdots \ldots \\
\cdots \ldots \\
\ldots\end{array}$ & $\begin{array}{r}0.9 \\
\ldots . . \\
\ldots .5 \\
.2 \\
\ldots \ldots \\
\ldots \ldots \\
\ldots \ldots\end{array}$ \\
\hline Total & 100.0 & 60.1 & 2.9 & .5 & .1 & .8 & 3.0 & 25.0 & .7 & 3.1 & .8 & 2.7 & .0 & .3 \\
\hline
\end{tabular}

TABLE 3.-Percentage of number of fairs and exhibitions devoted to agriculture, live stock, and related subjects, 1912, in each geographic division.

CLASSIFICATION BY AREA.

\begin{tabular}{|c|c|c|c|c|c|c|c|c|c|}
\hline Geographic division. & Total. & $\begin{array}{c}\text { Inter- } \\
\text { na- } \\
\text { tion- } \\
\text { al. }\end{array}$ & $\begin{array}{l}\mathrm{Na-} \\
\text { tion- } \\
\text { al. }\end{array}$ & $\begin{array}{l}\text { Inter- } \\
\text { state. }\end{array}$ & State. & $\begin{array}{c}\text { Inter- } \\
\text { coun- } \\
\text { ty. }\end{array}$ & $\begin{array}{c}\text { Coun- } \\
\text { ty. }\end{array}$ & $\begin{array}{l}\text { Lo- } \\
\text { cal. }\end{array}$ & $\begin{array}{l}\text { Not } \\
\text { re- } \\
\text { port- } \\
\text { ed. }\end{array}$ \\
\hline 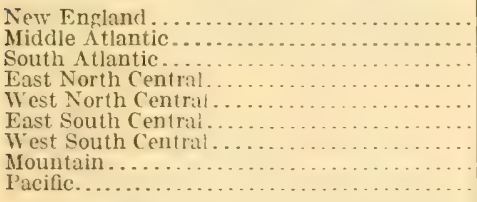 & $\begin{array}{r}8.4 \\
13.6 \\
7.7 \\
27.9 \\
20.9 \\
7.2 \\
5.1 \\
3.9 \\
5.3\end{array}$ & $\begin{array}{r}12.8 \\
29.4 \\
7.8 \\
21.6 \\
10.8 \\
2.9 \\
3.9 \\
3.9 \\
6.9\end{array}$ & $\begin{array}{r}14.7 \\
24.8 \\
8.5 \\
27.2 \\
11.6 \\
3.9 \\
5.4 \\
3.1 \\
.8\end{array}$ & $\begin{array}{r}7.5 \\
18.0 \\
13.0 \\
28.0 \\
13.5 \\
3.5 \\
5.0 \\
1.0 \\
10.5\end{array}$ & $\begin{array}{r}11.0 \\
9.0 \\
10.3 \\
27.1 \\
14.2 \\
6.4 \\
5.2 \\
7.1 \\
9.7\end{array}$ & $\begin{array}{r}5.2 \\
10.9 \\
7.5 \\
30.3 \\
25.5 \\
7.1 \\
4.7 \\
3.6 \\
5.2\end{array}$ & $\begin{array}{r}5.7 \\
12.2 \\
5.4 \\
26.3 \\
26.6 \\
10.7 \\
4.0 \\
4.8 \\
4.3\end{array}$ & $\begin{array}{r}18.8 \\
17.6 \\
2.5 \\
32.8 \\
15.2 \\
1.2 \\
4.4 \\
2.0 \\
5.2\end{array}$ & $\begin{array}{r}7.7 \\
10.5 \\
10.5 \\
27.6 \\
19.7 \\
7.9 \\
7.3 \\
4.0 \\
4.8\end{array}$ \\
\hline Total. & 100.0 & 100.0 & 100.0 & 100.0 & 100.0 & 100.0 & 100.0 & 100.0 & 100.0 \\
\hline
\end{tabular}


TABLE 3.-Percentage of number of fairs and exhibitions devoted to agriculture, live stock, and related subjects, 1912, in each geographic division-Continued.

KIND OF EXHIBIT.

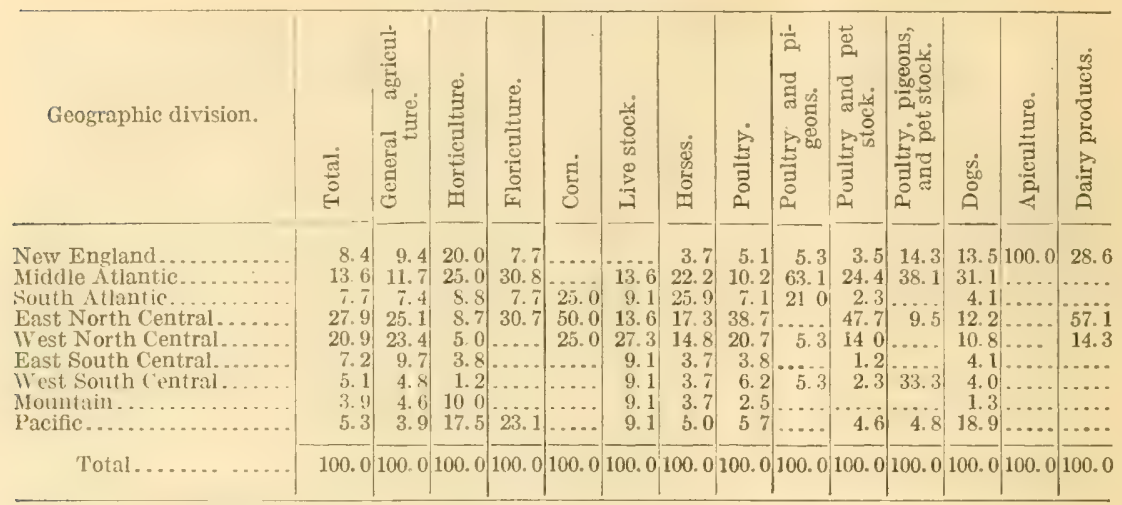

TABLE 4.-List of fairs and exhibitions devoted to agriculture, live stock, and other related subjects, by States, 1912.

ALABAMA.

\begin{tabular}{|c|c|c|c|c|}
\hline $\begin{array}{l}\text { Place where } \\
\text { held. }\end{array}$ & $\begin{array}{c}\text { Name of fair, exhibition, or } \\
\text { association. }\end{array}$ & Area covered. & $\begin{array}{l}\text { Time when usually } \\
\text { held, or begins, or } \\
\text { range of dates with- } \\
\text { in which it is held. }\end{array}$ & $\begin{array}{l}\text { Kind of } \\
\text { exhibit. }\end{array}$ \\
\hline 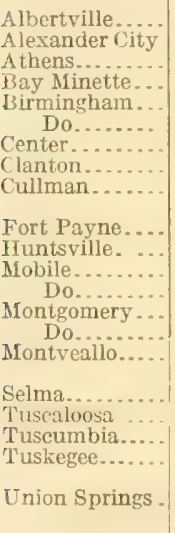 & 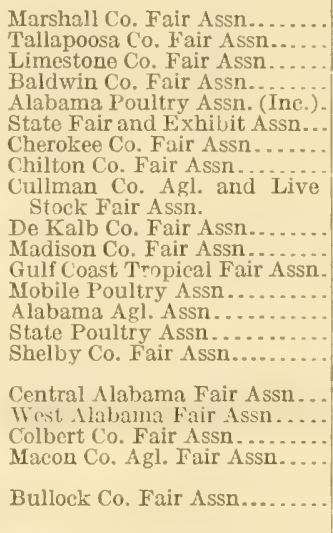 & 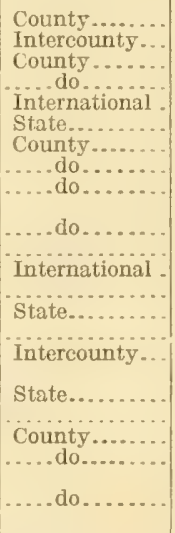 & 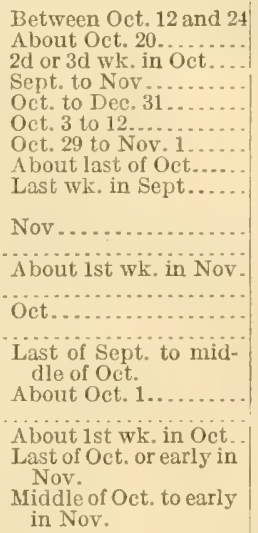 & $\begin{array}{c}\text { General agr. } \\
\text { Do. } \\
\text { Do. } \\
\text { Do. } \\
\text { Poultry. } \\
\text { General agr. } \\
\text { Do. } \\
\text { Do. } \\
\text { Do. } \\
\text { Do. } \\
\text { Do. } \\
\text { Do. } \\
\text { Poultry. } \\
\text { Genera? agr. } \\
\text { Poultry. } \\
\text { General agr. } \\
\text { Do. } \\
\text { Do. } \\
\text { Do. } \\
\text { Do. } \\
\text { Do. }\end{array}$ \\
\hline
\end{tabular}

ARIZONA.

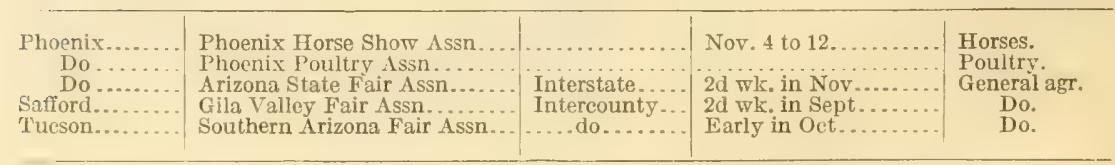

REQUEST.-It is requested that everybody who is able to do so will send to this department corrections of errors in this bulletin and additions to the list of fairs and exhibitions. 
TABLE 4.-List of fairs and exhibitions devoted to agriculture, live stock, and other related subjects, by States, 1912-Continued.

ARKANSAS.

\begin{tabular}{|c|c|c|c|c|}
\hline $\begin{array}{l}\text { Place where } \\
\text { held. }\end{array}$ & $\begin{array}{c}\text { Name of fair, exhibition, or } \\
\text { association. }\end{array}$ & Area covered. & $\begin{array}{l}\text { Time when usually } \\
\text { held, or begins, or } \\
\text { range of dates with- } \\
\text { in which it is held. }\end{array}$ & $\begin{array}{l}\text { - Kind of } \\
\text { exhibit. }\end{array}$ \\
\hline Ash Flat...... & Sharp Co. Fair Assn.... & County... & Last 2 wks. in Sept.... & General agr. \\
\hline Bentonville.... & $\begin{array}{l}\text { Benton Co. Horse and ifule } \\
\text { Show. }\end{array}$ & Intercounty... & Early in Oet.......... & $\begin{array}{l}\text { Horses and } \\
\text { mules. }\end{array}$ \\
\hline Do. & Benton Co. Hort. Soe......... & County . & Last of Oct. & Horticulture. \\
\hline I)o...... & Chicken Fair Assn...... & & & Poultry. \\
\hline $\begin{array}{l}\text { Berry ville...... } \\
\text { Carlisle......... }\end{array}$ & North Arkansas Fair Assn... & Intercounty... & About Oct. 1 . & General agr. \\
\hline $\begin{array}{l}\text { Carlisle....... } \\
\text { Clarksville... }\end{array}$ & $\begin{array}{l}\text { Central Arkansas Falr Assn.. } \\
\text { Clarksville Fair Assn. . . . . . }\end{array}$ & Local. & & $\begin{array}{l}\text { Do. } \\
\text { Do. }\end{array}$ \\
\hline Conw & Faulkner Co. Fair Isin.... . & Intercount & Oct. 1 to $15 .$. & Do. \\
\hline Eldor & Union Co. Fair Assn .... & & 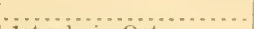 & Do. \\
\hline Fayetteville... & Washington Co. Fair Assn..... & Co & ist & Do. \\
\hline $\begin{array}{l}\text { Ft. Smith...... } \\
\text { Do........ }\end{array}$ & $\begin{array}{l}\text { Arkansas-Oklahoma Fair Assn } \\
\text { Ft. Smith Poulty Assn........ }\end{array}$ & In & $\mathrm{Oc}$ & $\begin{array}{l}\text { Do. } \\
\text { Poultry. }\end{array}$ \\
\hline $\begin{array}{l}\text { Forest City, } \\
\text { Holena, or } \\
\text { Marianna. } \\
\text { He len a, see } \\
\text { Forest City. }\end{array}$ & Phillips Co, Poultry Assn.... & National & About No & Do. \\
\hline Hope......... & $\begin{array}{l}\text { Hempstead Co. Union Fair } \\
\text { Assn. }\end{array}$ & & $\begin{array}{l}\text { Last of Sept. to early } \\
\text { in Oet. }\end{array}$ & General agr. \\
\hline $\begin{array}{l}\text { Hot Springs.... } \\
\text { Little Rock... }\end{array}$ & $\begin{array}{l}\text { Arkansas State Fair Assn...... } \\
\text { Little Rock Poultry Assn.... }\end{array}$ & $\begin{array}{l}\text { State.......... } \\
\text { National..... }\end{array}$ & $\begin{array}{l}\text { Oct. } 9 \text { to } 14 . . . \\
\text { Last of Nov. or early }\end{array}$ & $\begin{array}{l}\text { Do. } \\
\text { Poultry. }\end{array}$ \\
\hline $\begin{array}{l}\text { Marianna, see } \\
\text { Forest City. } \\
\text { Mena............ }\end{array}$ & & & & \\
\hline $\begin{array}{l}\text { Mena } \\
\text { Morrilton........... }\end{array}$ & $\begin{array}{l}\text { Mena and Polk Co. Fair Assn.. } \\
\text { Conway Co. Fair Assn }\end{array}$ & & & General agr. \\
\hline Piggott. & Clay Co. Fair Assn....... & $\begin{array}{l}\text { Intercounty... } \\
\text { County....... }\end{array}$ & Oet.... do & $\begin{array}{l}\text { Do. } \\
\text { Do. }\end{array}$ \\
\hline $\begin{array}{l}\text { Pine Blu } \\
\text { Prescott. }\end{array}$ & Pine Bluff Poultry Assn & & tenta & Poultry. \\
\hline & $\begin{array}{l}\text { Nevada Co, Farmers' Fair } \\
\text { Assn. }\end{array}$ & & & General agr. \\
\hline
\end{tabular}

CALIFORNTA.

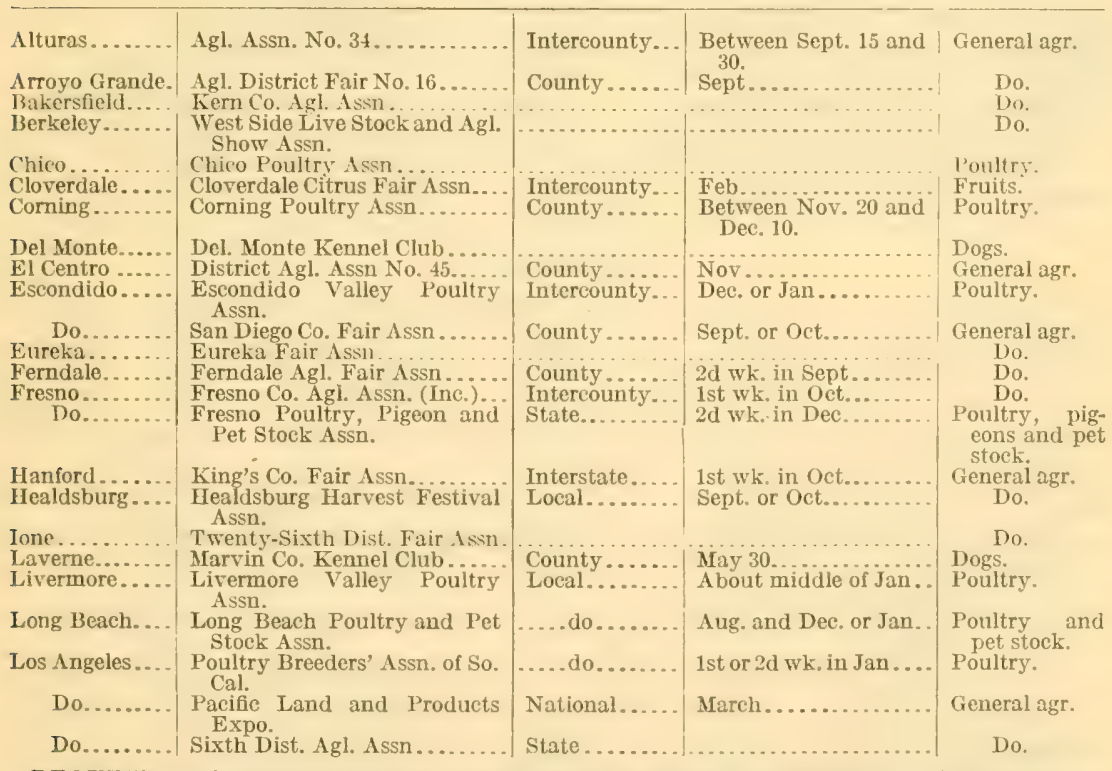

REQUEST.-It is requested that everybody who is able to do so will send to this department corrections of errors in this bulletin and additions to the list of fairs and exhibitions. $64267^{\circ}-13-3$ 
TABLE 4.--List of fairs and exhibitions devoted to agriculture, live stock, and other related subjects, by States, 1912-Continued.

CALIFORNIA-Continued.

\begin{tabular}{|c|c|c|c|c|}
\hline $\begin{array}{l}\text { Place where } \\
\text { held. }\end{array}$ & $\begin{array}{c}\text { Name of fair, exhibition, or } \\
\text { association. }\end{array}$ & Area covered. & $\begin{array}{l}\text { Time when usually } \\
\text { held, or begins, or } \\
\text { range of dates with- } \\
\text { in which it is held. }\end{array}$ & $\begin{array}{l}\text { Kind of } \\
\text { exhibit. }\end{array}$ \\
\hline Monrovia. & $\begin{array}{l}\text { San Gabriel Valley Poultry } \\
\text { Breeders' Assn. }\end{array}$ & Interstate..... & 1st part of Dec.. & Poultry. \\
\hline$\ldots$ & Napa Co. Poultry Assn ....... & Intercounty... & Between Dec. 18 and 23 & Do. \\
\hline & Alameda Co. Kennel Club.... & Interstate ..... & May or Oct........... & Dogs. \\
\hline Do. & Alameda Co. Poultry Assn..... & ..... do... & Last wk. in Sept...... & Poultry. \\
\hline Do. & $\begin{array}{l}\text { California Assn. of Nursery- } \\
\text { men. }\end{array}$ & State.. & Nov.............. & Fruits. \\
\hline Otoville. & $\begin{array}{l}\text { Oroville, Orange, and Olive } \\
\text { Expo. }\end{array}$ & County... & 1 st or $2 d \mathrm{wk}$. in Dee... & $\begin{array}{l}\text { Citrus fruit } \\
\text { and olives. }\end{array}$ \\
\hline P'asadena. & Pasadena Hort. Soc.... . . . . . . & Local. & $\begin{array}{l}\text { 1st or } 2 \mathrm{~d} \text { wk. in Apr. } \\
\text { and last wk. in Oet. }\end{array}$ & Horticulture. \\
\hline & Pasadena Kennel Club.. & International. & March................ & Dogs. \\
\hline $\begin{array}{r}\text { Do } \\
\text { Petalu }\end{array}$ & Pasadena Poultry Assn ........ & Interstate..... & Dec. $1 \ldots . . . . . .$. & Poultry. \\
\hline Petalu & $\begin{array}{l}\text { Petaluma Poultry Fanciers' } \\
\text { Assn. }\end{array}$ & Local.... & About 1st wk. in Dec.. & Do. \\
\hline Sacramento & California State $\Lambda$ gl. Soc...... & State. & $\begin{array}{l}\text { 1st, } 2 \mathrm{~d} \text { or } 3 \mathrm{~d} \text { wk. in } \\
\text { Sept. }\end{array}$ & General agr. \\
\hline Do.. & $\begin{array}{l}\text { Northern California Citrus } \\
\text { Fair Assn. }\end{array}$ & do & Spring.............. & Citrus fruit. \\
\hline Do. & $\begin{array}{l}\text { Northern California Kennel } \\
\text { Club. }\end{array}$ & International.. & Fall. & Dogs. \\
\hline San Bernardino & National Orange Show Assn ... & Local. & Feb. & Citrus fruit. \\
\hline $\begin{array}{l}\text { San Die } \\
\text { San Fra }\end{array}$ & San Diego Poultry Assn....... & & & $\begin{array}{l}\text { Poultry. } \\
\text { Dogs. }\end{array}$ \\
\hline San Jose... & $\begin{array}{l}\text { Santa Clara Valley Poultry } \\
\text { Assn. }\end{array}$ & St & 1st wh. & Poultry. \\
\hline Do & Santa Clara Co. Fair Assn...... & County & Sept & General agr. \\
\hline$D$ & $\begin{array}{l}\text { Santa Clara County Kennel } \\
\text { Club. }\end{array}$ & & & Dogs. \\
\hline $\begin{array}{l}\text { San Mate } \\
\text { Santa An }\end{array}$ & San Mateo Kennel Club. ....... & Inte: & About Sep & $\begin{array}{l}\text { Do. } \\
\text { Poultry }\end{array}$ \\
\hline $\begin{array}{l}\text { Santa Ana..... } \\
\text { Santa Barbara. }\end{array}$ & Santa Barbara Poultry Assn... & $\mathrm{Co}$ & $\Lambda b c$ & Do. \\
\hline Santa Cruz.... & Santa Cruz Co. Kennel Club... & State..... & Midsummer........... & Dogs. \\
\hline Do.. & $\begin{array}{l}\text { Santa Cruz Co. Poultry and } \\
\text { Pet Stock Assn. }\end{array}$ & Intercoun & A bout July 22 to 2 & $\begin{array}{l}\text { Poultry and } \\
\text { pet stock. }\end{array}$ \\
\hline Santa Ros: & Rose Carnival Assn ........... & z.d d & A bout 1st wk. in May.. & Floriculture. \\
\hline $\begin{array}{l}\text { Saratog } \\
\text { Sebasto }\end{array}$ & Saratoga Improvement $\Lambda$ ssn . - & Local... & About March . .... & $\begin{array}{l}\text { Do. } \\
\text { Apples. }\end{array}$ \\
\hline $\begin{array}{l}\text { Sebasto } \\
\text { Stockto }\end{array}$ & $\begin{array}{l}\text { Gravenstein Apple Show Assn. } \\
\text { San Joaquin Poultry Assn .... }\end{array}$ & $\begin{array}{l}\text { County } \\
\text { Internatic }\end{array}$ & $\begin{array}{l}\text { Between Aug. } 8 \text { and } 20 . \\
\text { Fall.... . . . . . . . . . }\end{array}$ & $\begin{array}{l}\text { Apples. } \\
\text { Poultry. }\end{array}$ \\
\hline Visalia & Tulare Agl. Fair Assn........ & 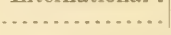 & 20 & General agr. \\
\hline $\begin{array}{l}\text { IV:alnut Creek. } \\
\text { IVatsonville.. }\end{array}$ & Walnut Creek Faur Assn . . . . . & & & Do. \\
\hline $\begin{array}{l}\text { Watsonville... } \\
\text { Do......... }\end{array}$ & $\begin{array}{l}\text { Pajaro Valley Poultry Assn ... } \\
\text { Watsonville Apple Annual }\end{array}$ & State.. & 2d wk. in Oct. & $\begin{array}{l}\text { Poultry. } \\
\text { Apples. }\end{array}$ \\
\hline IVoodland & $\begin{array}{l}\text { Assn. } \\
\text { Woodland Driving Club... }\end{array}$ & County... & A bout Aug. 9 to 12. & Horses. \\
\hline
\end{tabular}

COLORADO.

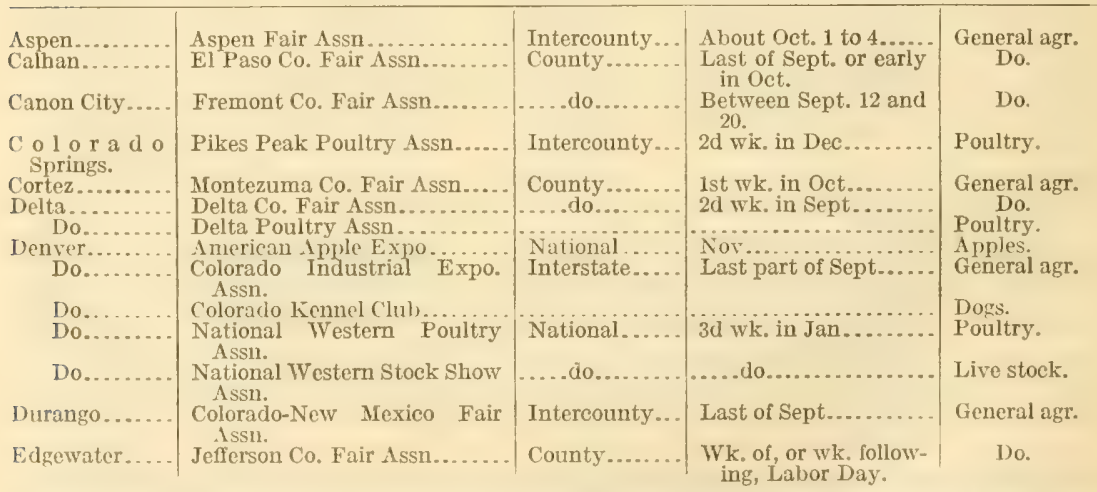

IREQUEST.-It is requested that everybody who is able to do so will send to this department corrections of errors in this bulletin and additions to the list of fairs and exhibitions. 
TABLE 4.-List of fairs and exhibitions devoted to arriculture, live stock, and other related subjects, by States, 1912-Continued.

COLORADO-Continued.

\begin{tabular}{|c|c|c|c|c|}
\hline $\begin{array}{l}\text { Place where } \\
\text { held. }\end{array}$ & $\begin{array}{c}\text { Name of fair, exhibition, or } \\
\text { association. }\end{array}$ & Area covered. & $\begin{array}{l}\text { Time when usually } \\
\text { held, or begins, or } \\
\text { range of dates with- } \\
\text { in which it is held. }\end{array}$ & $\begin{array}{l}\text { Kind of } \\
\text { exhibit. }\end{array}$ \\
\hline Fort Collins. & $\begin{array}{l}\text { Northern Colorado Poultry } \\
\text { Assn. }\end{array}$ & Intercounty... & About Dec. 13 to $18 .$. & Poultry. \\
\hline Fort Morgan... & Easterm Colorado Poultry Assn & ....do.. & 1st wk. in Jan.... & Do. \\
\hline 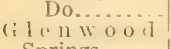 & $\begin{array}{l}\text { Morgan Co, Fair Assn.......... } \\
\text { Distriet Fuir Assn............ }\end{array}$ & County. & Sept........... & $\begin{array}{l}\text { General agr. } \\
\text { Do. }\end{array}$ \\
\hline $\begin{array}{l}\text { Springs. } \\
\text { Grand Junetion }\end{array}$ & $\begin{array}{l}\text { Mesa Co. Industrial and Fruit } \\
\text { Fair Assn. }\end{array}$ & County & 4 th wk. in Sept & Do. \\
\hline Greeley ........ & WVeld Co. Fair Assn ...., ...... & & I & Do. \\
\hline$\cdots$ & $\begin{array}{l}\text { Holly Poultry Fanciers' Assn. } \\
\text { Hotchkiss Fair Assn.......... }\end{array}$ & $\begin{aligned} \text { Loca } \\
\ldots . . . \mathrm{d}\end{aligned}$ & $\begin{array}{l}\text { Dec. or Ja } \\
\text { lst wk, in }\end{array}$ & $\begin{array}{l}\text { Poultry. } \\
\text { General a }\end{array}$ \\
\hline-1 & Prowers Co. Fair Assn........ & County. & Aug.................... & Do. \\
\hline & Arapahoe Co. Fair Assu....... & & $\begin{array}{l}\text { Last of Sept. or early } \\
\text { in Oct. }\end{array}$ & Do. \\
\hline Loveland. & $\begin{array}{l}\text { Northern Colorado Poultry } \\
\text { Assn. }\end{array}$ & Intercounty... & About Dec, 13 to $18 \ldots$ & \\
\hline Monte Vista. & $\begin{array}{l}\text { San Luis Valley Stock Show } \\
\text { and Fair Assn. }\end{array}$ & & Last part of Sept...... & General agr. \\
\hline $\begin{array}{l}\text { Miontrose } \\
\text { Pueblo.. }\end{array}$ & Thern Slope Fair Assn... & Cou & 3d wk. in Sept. . & Do. \\
\hline Do. & $\begin{array}{l}\text { Colorado state Tair Assn... } \\
\text { Pueblo Poultry Assn... . . . }\end{array}$ & State & $D_{t}$ & $\begin{array}{l}\text { Do. } \\
\text { Poultry. }\end{array}$ \\
\hline Riocky For & Arkansas Valley Fair Assu... & Intercou & 1st wk. in Sept.. & General agr. \\
\hline Sterling. & Logan Cu. Poultry Assu....... & International.. & Dec. or $\operatorname{Jan} . . . . . . . . .$. & Poultry. \\
\hline Trinidad. & $\begin{array}{l}\text { Trinidad-Las Animas Co. Fair } \\
\text { Assn. }\end{array}$ & County........ & About middle of Sept. & General agr. \\
\hline Wray. & Yuma Co. Fair Assu... & & 1st wk. in Sept & Do. \\
\hline
\end{tabular}

CONNECTICUT

\begin{tabular}{|c|c|c|c|c|}
\hline \multicolumn{5}{|l|}{$\begin{array}{l}\text { Barkhamsted, } \\
\text { see Riverton. }\end{array}$} \\
\hline Beriin ......... & Connecticut State $\mathbf{A g l}$. Soc.... & State.. & Last wk. in Sept. & General agr. \\
\hline Branford ........ & Branford Fair Assn ............. & & $\ldots \ldots \ldots$ & Do. \\
\hline $\begin{array}{r}\text { Bridgeport..... } \\
\text { Do........ }\end{array}$ & $\begin{array}{l}\text { Bridgeport Poultry Assn.(Ine.) } \\
\text { Bridgeport Poultry Pigeon. }\end{array}$ & Interstate..... & Irregular............... & Poultry. \\
\hline & and Pet Stock Assn. (Inc.). & & & $\begin{array}{l}\text { eons, and pet } \\
\text { stock. }\end{array}$ \\
\hline Brooklyn. & Windham Co. Agl. Soc... & County........ & Last of Sept..... & General agr. \\
\hline Cheshire. & Cheshire Poultry Assn ....... & Local.... & 1st or $2 \mathrm{~d} w \mathrm{k}$. in Nov... & Poultry. \\
\hline $\begin{array}{l}\text { Chester......... } \\
\text { Clinton......... }\end{array}$ & $\begin{array}{l}\text { Chester Agl. and Mechl. Soc... } \\
\text { Clinton Agl. Soc............... }\end{array}$ & .....do. & $2 d$ or $3 d w k$. in Sept... & General agr. \\
\hline Colchester..... & Colchester Grange Corporation. & Local. & Between Sept. 5 and & Do. \\
\hline $\begin{array}{l}\text { Colchrook, see } \\
\text { Riverton. }\end{array}$ & & & & \\
\hline Danbury ....... & Danbury Agl. Soc.. & National. & 1st wk. in Oct. & Do. \\
\hline East Haddam.. & $\begin{array}{l}\text { East Haddam Grange Fair } \\
\text { Assn. }\end{array}$ & Intercounty... & Sept... & Geutry. \\
\hline $\begin{array}{l}\text { East Windsor. - } \\
\text { Ellington. }\end{array}$ & Union Agl. Soc... & ... & & Do. \\
\hline $\begin{array}{l}\text { Ellington ...... } \\
\text { Enfigelil........ }\end{array}$ & $\ldots$ do ....................... & 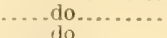 & & Do. \\
\hline Fitchville...... & New London Co. Fair Assn... & & & Do. \\
\hline Goshen.. & Goshen Agl. Soc............... & Local. . & Labor Day and day & Do. \\
\hline Grantis: & 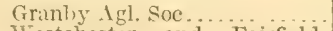 & & & Do. \\
\hline Greenwi & $\begin{array}{l}\text { Westchester and Fairfield } \\
\text { Hort. Soc. }\end{array}$ & Intercounty... & June and Nov. & Horticulture. \\
\hline Guilford.. & Guilford Agl. Soc.................... & Local.... & Last Wed. in Sep & General agr. \\
\hline Do. & $\begin{array}{l}\text { Shore Line Poultry, Pigeon, } \\
\text { and Pet Stock Assn. }\end{array}$ & Interstate & 1st wk. in Dec... & $\begin{array}{l}\text { Poultry, pig- } \\
\text { eons, and pet } \\
\text { stock. }\end{array}$ \\
\hline Iaddam Neck. & $\begin{array}{l}\text { Haddam Neck Grange Agl. } \\
\text { Assn. }\end{array}$ & Loca & Labor Day..... & General agr. \\
\hline Hamburg...... & Lyme Grange Fair Assn...... & .... do & 3d. Wed. in Sep & Do. \\
\hline Do.......... & $\begin{array}{l}\text { New England Fruit Show Assn } \\
\text { Connecticut Dairymen's Assn. }\end{array}$ & Stat & & $\begin{array}{l}\text { Horticulture. } \\
\text { Dairving. }\end{array}$ \\
\hline Do... & Connecticut Fair Assn....... & Interstate..... & Ist wk. in Sept. & General agr. \\
\hline Do......... & Connecticut Hort. Soc........ . & State.......... & Sept.................... & Horticulture. \\
\hline $\begin{array}{l}\text { II a rw in ton } \\
\text { Center. }\end{array}$ & Harwinton $\Lambda$ gl. Soc.......... & Local.... & $\begin{array}{l}\text { Ist Tues. after 1st Mon. } \\
\text { in Oct. }\end{array}$ & General agr. \\
\hline
\end{tabular}

REQUEST.-It is requested that everybody who is able to do so will send to this department corrections of errors in this bulletin and additions to the list of fairs and exibitions. 
TABLE 4.-List of fairs and exhibitions devoted to agriculture, live stock, and other related subjects, by States, 1912-Continued.

CONNECTICUT-Continued.

\begin{tabular}{|c|c|c|c|c|}
\hline $\begin{array}{l}\text { Place where } \\
\text { held. }\end{array}$ & $\begin{array}{c}\text { Name of fair, exhibition, or } \\
\text { association. }\end{array}$ & Area, covered. & $\begin{array}{l}\text { Time when usually } \\
\text { held, or begins, or } \\
\text { range of dates with- } \\
\text { in which it is held. }\end{array}$ & $\begin{array}{l}\text { Kind of } \\
\text { exhibit. }\end{array}$ \\
\hline IIazardville & Hazardville Fair Assn. & & & General agr. \\
\hline & Iovington Fair Assn. & & & 1). \\
\hline Madisor & $\begin{array}{l}\text { Madison Agl. and Industrial } \\
\text { Soc. }\end{array}$ & Local. & Sept.. & Do. \\
\hline Manchest & Manchester Poultry Assn..... & & & Poultry. \\
\hline Meriden & Meriden Poultry Assn. (Inc.).. & National & Christmas wk. & Do. \\
\hline Do. & Meriden Fair Assn ............ & & & General agr. \\
\hline Milford. & Connecticut Pomological Soc.. & State & Last wk. in Sept. & Iorticulture. \\
\hline Naugatu & $\begin{array}{l}\text { Beacon Valley Driving and } \\
\text { Agl. Assn. (Inc.). }\end{array}$ & Local. & $2 \mathrm{~d} w \mathrm{k}$. in & General agr. \\
\hline New Hav & New Haven Hort. Soc........ & Count & Sept. or Nov..... & IIorticulture. \\
\hline New Lor & New Londion Hort. Soc. & Local & $\begin{array}{l}\text { Last of Aug. and 1st } \\
\text { wk. in Now. }\end{array}$ & Do. \\
\hline Do..... & $\begin{array}{l}\text { So. New England Poultry and } \\
\text { Pet Stock Assn. }\end{array}$ & Interstate..... & $\begin{array}{l}\text { A bout middle of Nov. } \\
\text { or Dec. }\end{array}$ & $\begin{array}{l}\text { Poultry and } \\
\text { pet stoek. }\end{array}$ \\
\hline Newton & Newton Fair Assn........... & & & General agr. \\
\hline Norfolk........ & Norfolk Agl. Assu.............. & Loc & pt........ & Do. \\
\hline $\begin{array}{l}\text { North stoning- } \\
\text { ton. }\end{array}$ & $\begin{array}{l}\text { Assn. } \\
\text { Astong }\end{array}$ & Cour & Last of Sept..... & Do. \\
\hline Norwich...... & New London Co. Agl. Sac..... & -...de do & Labc & Do. \\
\hline Do.. & $\begin{array}{l}\text { New London Co. Hort. Soc. } \\
\text { (Inc.). }\end{array}$ & Interc & $\begin{array}{l}\text { Rose show in une and } \\
\text { dablia show in Sept. }\end{array}$ & Floriculture. \\
\hline $\operatorname{rang} \rho$ & Orange Agl. Soc . ...... & Cou & 1st wk. in Sept........ & General agr. \\
\hline Rockville. & Rockville Fair Assn.......... & $\mathrm{Co}$ & About middle of Sept.. & Do. \\
\hline Riverton. & $\begin{array}{l}\text { Union Agl. Soc. of Barkham- } \\
\text { sted, Colebrook, and Hart- } \\
\text { land (Inc.). }\end{array}$ & Lo & ...................... & Do. \\
\hline $\begin{array}{l}\text { Simsbury ...... } \\
\text { Somers....... }\end{array}$ & Simsbury Agl. Soc... & & & Do. \\
\hline $\begin{array}{l}\text { Somers } \\
\text { South Wood- }\end{array}$ & $\begin{array}{l}\text { Union Agl. Soc........ } \\
\text { Woodstock Agl. Soc.. }\end{array}$ & $\begin{array}{l}\text { Interc } \\
\text { Local }\end{array}$ & $\begin{array}{l}2 d \text { or } 3 d \text { wk. in Sept... } \\
\text { 1st wk. nearest } 12 \text { th of } \\
\text { month. }\end{array}$ & $\begin{array}{l}\text { Do. } \\
\text { Do. }\end{array}$ \\
\hline Stafford Springs & Staftord Springs Agl. Soc ...... & glo & $2 d$ w. in oct. . & Do. \\
\hline Stamford........ & Stamford Poultry Assn. (Inc.). & ational.. & Middle of Jan.. & Poultry. \\
\hline $\begin{array}{l}\text { Suffield ........ } \\
\text { Wallingford.... }\end{array}$ & 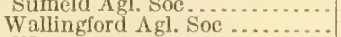 & $\mathrm{Loc}$ & Set. 23 to 28 . & $\begin{array}{c}\text { General agr. } \\
\text { Do. }\end{array}$ \\
\hline Waterbury ..... & $\begin{array}{l}\text { Waterbury Poultry and Pet } \\
\text { Stock Assn. }\end{array}$ & International. & Dec. 17 to $20 \ldots . .$. & $\begin{array}{l}\text { Poultry and } \\
\text { pet stock. }\end{array}$ \\
\hline West Hartford. & Connecticut Bee-Keepers' Assn & Stat & 1st wk. in Sep & Apiculture. \\
\hline West Haven... & West Haven Poultry Assn.... & National...... & $3 d$ or 4 th wk, in Nov.. & Poultry. \\
\hline Willimantic & Horse Shoe Park Agl. Assn.... & Intercounty... & $\begin{array}{l}\text { Wk. following wk. of } \\
\text { Labor Day. }\end{array}$ & General agr. \\
\hline Winsted. & $\begin{array}{l}\text { Western Connecticut Poultry } \\
\text { Assn. }\end{array}$ & Interstate. & $\begin{array}{l}\text { Last of Dec. or 1st of } \\
\text { Jan. }\end{array}$ & Poultry. \\
\hline Wolco & Wolcott Agl. Soc... & & & General agr. \\
\hline
\end{tabular}

DELAWARE.

\begin{tabular}{|c|c|c|c|c|}
\hline $\begin{array}{l}\text { Dover....... } \\
\text { Wilmington... } \\
\text { Do....... } \\
\text { Do....... } \\
\text { Do......... } \\
\text { Do....... }\end{array}$ & $\begin{array}{l}\text { Deleware Corn Growers' Assn . } \\
\text { Delaware State Fair Assn ..... } \\
\text { Diamond State Poultry and } \\
\text { Pigeon Assn. } \\
\text { Peninsula Hort. Soc........... } \\
\text { Wilmington Horse Show A.ssn. } \\
\text { Wilmington Kennel Club..... }\end{array}$ & $\begin{array}{l}\text { State......... } \\
\text { International.. } \\
\text { Interstate..... } \\
\text { National........ }\end{array}$ & 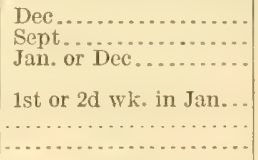 & $\begin{array}{l}\text { General agr. } \\
\text { Do. } \\
\text { Poultry and } \\
\text { pigeons. } \\
\text { Horticulture. } \\
\text { Horses. } \\
\text { Dogs. }\end{array}$ \\
\hline
\end{tabular}

DISTRICT OF COLUMBIA.

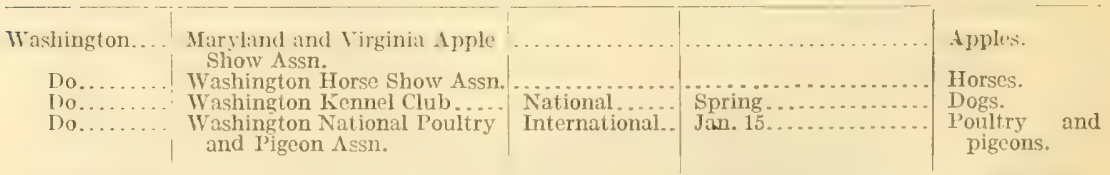

IREQUEST.-It is requested that everybody who is able to do so will send to this department corrections of errors in this bulletin and additions to the list of fairs and exhibitions. 
TABIE 4.-List of fairs and exhibitions devoted to agriculture, live stock, and other related subjects, by States, 1912 -Continued.

\section{FLORIDA.}

\begin{tabular}{|c|c|c|c|c|}
\hline $\begin{array}{c}\text { Place where } \\
\text { held. }\end{array}$ & $\begin{array}{c}\text { Name of fair, exhibition, or } \\
\text { association. }\end{array}$ & Irea covered. & $\begin{array}{l}\text { Time when usually } \\
\text { held, or begins, or } \\
\text { range of dates with- } \\
\text { in which it is held. }\end{array}$ & $\begin{array}{l}\text { Kind of } \\
\text { exhibit. }\end{array}$ \\
\hline 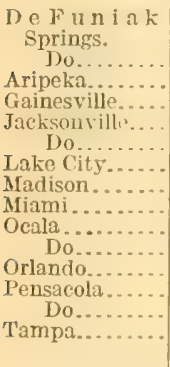 & 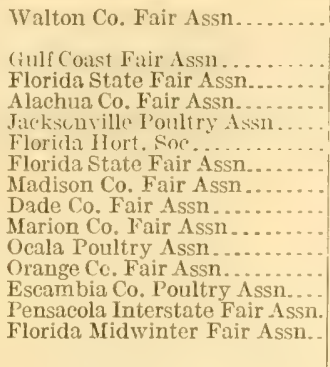 & 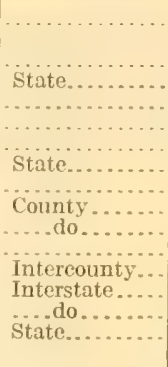 & 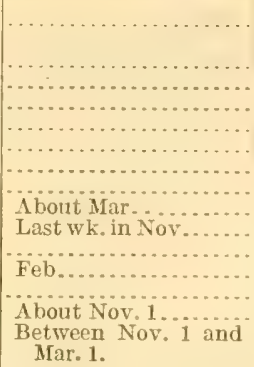 & $\begin{array}{l}\text { General agr. } \\
\text { Do. } \\
\text { Do. } \\
\text { Do. } \\
\text { Poultry. } \\
\text { Horticiliture. } \\
\text { General agr. } \\
\text { Do. } \\
\text { Do. } \\
\text { Do. } \\
\text { Poultry. } \\
\text { General agr. } \\
\text { Poultry. } \\
\text { General igr. } \\
\text { Do. }\end{array}$ \\
\hline
\end{tabular}

GEORGIA.

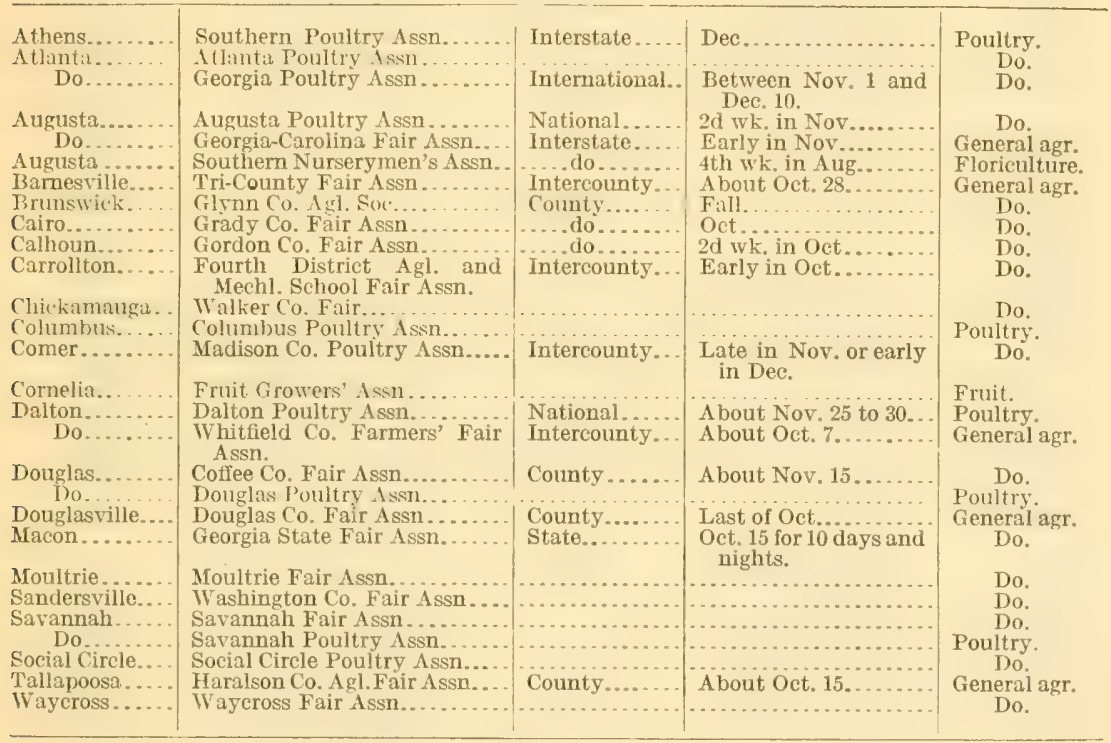

IDAHO.

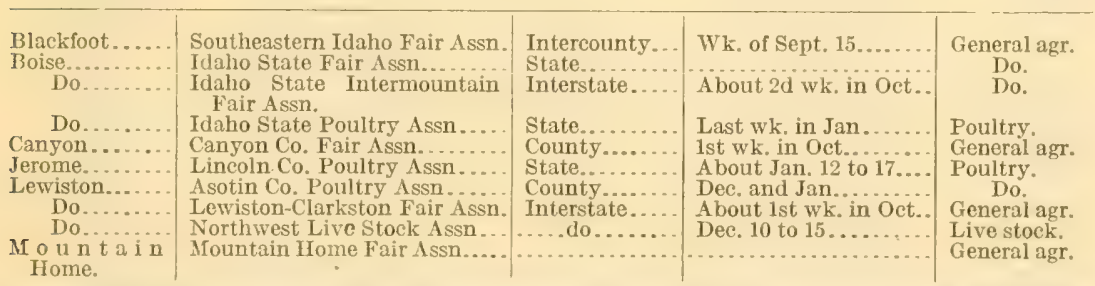

REQUEST.-It is requested that everybody who is able to do so will send to this department corrections of errors in this bulletin and additions to the list of fairs and exhibitions. 
TABLE 4.-List of fairs and exhibitions devoted to agriculture, live stock, and ather related subjects, by States, 1912-Continued.

IDAHO-Continued.

\begin{tabular}{|c|c|c|c|c|}
\hline $\begin{array}{l}\text { Place where } \\
\text { held. }\end{array}$ & $\begin{array}{c}\text { Name of fair, exhibition, or } \\
\text { association. }\end{array}$ & Area covered. & $\begin{array}{l}\text { Time when usually } \\
\text { held, or begins, or } \\
\text { range of dates with- } \\
\text { in which it is held. }\end{array}$ & $\begin{array}{l}\text { Kind of } \\
\text { exhibit. }\end{array}$ \\
\hline Nez Perce... & $\begin{array}{l}\text { Nez Perce Co. Fair and Rac- } \\
\text { ing Assn. }\end{array}$ & & & General agr. \\
\hline Paris.. & Bear Lake Co. Fair Assn ..... . & Counts. & Sept.... & Do. \\
\hline Preston... & Preston Park and Fair Assn ... & $\ldots$ do.... & About Sept. 20 to $25 .$. & 1)o. \\
\hline Shoshone...... & Lincoln Co. Fair Assn....... & Intercolint 5 . & 1st or $2 d$ wh. in Oet... & Po. \\
\hline Twin Falls.... & $\begin{array}{l}\text { Twin Falls Co. Industrial } \\
\text { Expo. }\end{array}$ & County.... & Middle of Oct........ & 10. \\
\hline $\begin{array}{l}\text { Do... } \\
\text { Wendell. }\end{array}$ & $\begin{array}{l}\text { Twin Falls and So. Idaho } \\
\text { Poultry Assn. } \\
\text { Wendell Fair Assn............ }\end{array}$ & Interstate. & 1st wh. in Jan. & $\begin{array}{l}\text { Poultry. } \\
\text { General agr. }\end{array}$ \\
\hline
\end{tabular}

ILLINOIS.

\begin{tabular}{|c|c|c|c|c|}
\hline sion & Albion Poultry Assn. . & & & oultry. \\
\hline & Edwards Co. Fair Assn & County & Between Sept. 10 and 20 & General agr. \\
\hline Aledo. & Mercer Co. Agl. Soc..... & Interstate.... & 3d wk. in Sept........ & Do. \\
\hline Altamo & Altamont Agl. Fair Assn.... & Lneal........ & Last wk. in Aug . ..... & Do. \\
\hline Alton. & Alton Poultry Assn.......... & & & Poultry. \\
\hline$\cdots$ & Lee Co. Fair Assn . . . . . . . & County ....... & 3d wk. in Sept. & General agr. \\
\hline $\begin{array}{l}\text { Anna... } \\
\text { Astoria. }\end{array}$ & $\begin{array}{l}\text { Southern Illinois Fair Assn.... } \\
\text { Astoria Poultry Assn........ }\end{array}$ & Interuational. . & Last Tues. & $\begin{array}{l}\text { Do, } \\
\text { Poultry, }\end{array}$ \\
\hline Atlant: & Atlanta Union Central Agl.Soc. & intercounty. & ist wk in Sept. & General agr. \\
\hline rora & Fox River Fanciers' Assn.... & Loc:il. ........ & Last wh. in Jan. . & Poultry. \\
\hline Av & Avon Fair and Improvement & & & General agr. \\
\hline & Winnebago Co. Fair Assn..... & County...... & Last wk. in Aug & Do. \\
\hline & $\begin{array}{l}\text { St. Clair Co. Fair Assn and } \\
\text { Driving Club. }\end{array}$ & inty. & $2 \mathrm{~d} v$ & Do. \\
\hline Belvider & Belvidere Poultry Assn. ..... & & & Poultry. \\
\hline .. & Boone Co. Agl. Soc....... & Count & lst wh. in & General agr. \\
\hline $\mathrm{Be}$ & Benton Poultry Assn ......... & & & Poultry. \\
\hline $\begin{array}{l}\text { Be } \\
\text { Bli }\end{array}$ & ultry Assn... & & & Do. \\
\hline$\cdots$ & $\begin{array}{l}\text { Blue 1sland Poultry Assn.... } \\
\text { Bowen Korn Karnival Assn... }\end{array}$ & Locitl. & $2 \mathrm{~d}$ wk. in Oct... & $\begin{array}{l}\text { Do. } \\
\text { Com. }\end{array}$ \\
\hline .... & Breese Driving and Fair Assn. & County.. & Sept. $17 \ldots . .$. & General agr. \\
\hline Bushnell & Bushnell Fair Assn........... & .... do........ & in $A u g . . . . .$. & Do. \\
\hline Camar & $\begin{array}{l}\text { Camargo Grain and Poultry } \\
\text { Assn. }\end{array}$ & Local......... & Ist part of Dec........ & Poultry. \\
\hline $\begin{array}{r}\text { Do.......... } \\
\text { Cambridge..... }\end{array}$ & $\begin{array}{l}\text { Douglas Co. Agl. Assn ........ } \\
\text { Henry Co. Agl. Board........ }\end{array}$ & $\mathrm{Cou}$ & $\begin{array}{l}\text { 1st half of Sept.... } \\
3 \mathrm{~d} \text { wk. in Aug.... }\end{array}$ & $\begin{array}{c}\text { General agr. } \\
\text { Do. }\end{array}$ \\
\hline t.... & Camp Point Poultry Assn... & Intercous & or De & Poultry. \\
\hline $\mathrm{Ca}$ & $\begin{array}{l}\text { Fulton Co. Poultry Breeders' } \\
\text { Assn. }\end{array}$ & County . & A bout last wk. in Dec. & Do. \\
\hline Carlinvill & $\begin{array}{l}\text { Macoupin Co. Fair and Agl. } \\
\text { Assn. }\end{array}$ & Interstate & Oct. 1 to & General agr. \\
\hline Carmi & White Co. Agl. Soc...... . . & County & 1st wk. in & Do. \\
\hline & Greene Co. Fair Assn.... & ..... do & Middle of Oct... & Do. \\
\hline & Casey Poultry Assn ....... & …‥ & ... & Poultry. \\
\hline $\begin{array}{l}\text { Centralia } \\
\text { Champai }\end{array}$ & Centralia Poultry Assn ........ & & & Do. \\
\hline Champai & $\begin{array}{l}\text { Champaign Co. Poultry and } \\
\text { Pet Stock Assn. }\end{array}$ & Intercount & $\begin{array}{l}\text { Last wk. in Dec. or lst } \\
\text { wk. in Jan. }\end{array}$ & $\begin{array}{l}\text { Poultry and } \\
\text { pei stock. }\end{array}$ \\
\hline & Illinois State Hort. Soc. . & Stat & 1st wk, in Dec. & Hort:culture. \\
\hline Chicago........ & 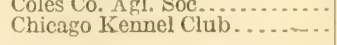 & International. & $\begin{array}{l}\text { Last wk. in Aug...... } \\
\text { 1st wk. preceding Holy }\end{array}$ & $\begin{array}{l}\text { Genera } \\
\text { Dogs. }\end{array}$ \\
\hline Do & $\begin{array}{l}\text { Great Mid-West Poultry and } \\
\text { Pet Stock Assn. }\end{array}$ & .. & D & $\begin{array}{l}\text { Poultry and } \\
\text { pet stock. }\end{array}$ \\
\hline & Hort. Soe. of Chicago . . ...... . . & Nat & Mi & Horticultare. \\
\hline & International LiveStock Expo. & Internatio & $\begin{array}{l}\text { 1st Sat. after last } \\
\text { Thurs, in Nov. }\end{array}$ & Live stock. \\
\hline Do & National Dairy Show Assn.... & Natic & & $\mathrm{D}$ \\
\hline $\begin{array}{l}\text { Do. } \\
\text { Colches }\end{array}$ & $\begin{array}{l}\text { U.S.Land and Irrigation Expo. } \\
\text { Colchester Poultry Assn...... }\end{array}$ & In & $\mathrm{F}$ & $\begin{array}{l}\text { General agr. } \\
\text { Poultry. }\end{array}$ \\
\hline & Rock Creek Fair Assn ......... & Local. & in Sept.. & General agr. \\
\hline & Vermilion Co. Fanciers' Assn.. & Intercounty. & 2 d full wk. in Jan. & Poultry. \\
\hline & $\begin{array}{l}\text { Decatur Poultry and Pet } \\
\text { Stock Assn. }\end{array}$ & County.. & & $\begin{array}{l}\text { Pou!try and } \\
\text { pet stock. }\end{array}$ \\
\hline $\begin{array}{l}\text { Do. } \\
\text { Kali }\end{array}$ & Decatur Trotting Assn........ & Local. & Au & IIorses. \\
\hline & $\begin{array}{l}\text { Kisnwaukee Poultry and Fan- } \\
\text { ciers' Assn. }\end{array}$ & & & rY. \\
\hline & & & & $\mathrm{D}$ \\
\hline
\end{tabular}

REQUEST.-It is requested that everybody who is able to do so will send to this department corrections of errors in this bulletin and additions to the list of fairs and exhibitions. 
TABLE 4.-List of fairs and exhibitions devoted to agrieulture, live slock, and olher related subjects, by States, 1912-Continued.

IILINOIS-Continued.

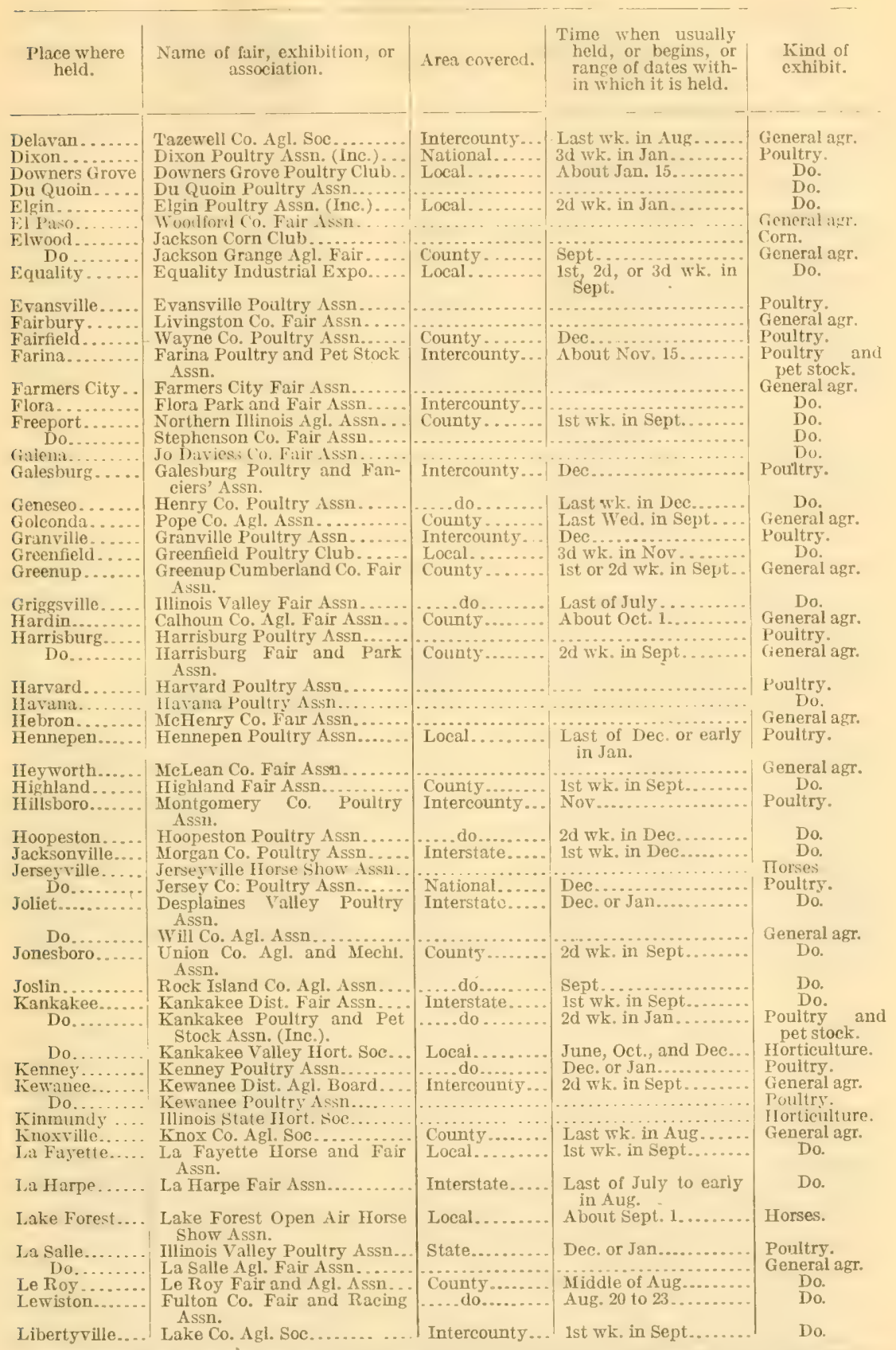

REOUES'T.-It is requested that everybody who is able to do so will send to this department corrections of errors in this bulletin and additions to the list of fairs and exhlbitions. 
TABLE 4.-List of fairs and exhibitions devoted to agriculture, live stock, and other related subjects, by States, 1912-Continued.

ILLINOIS-Continued.

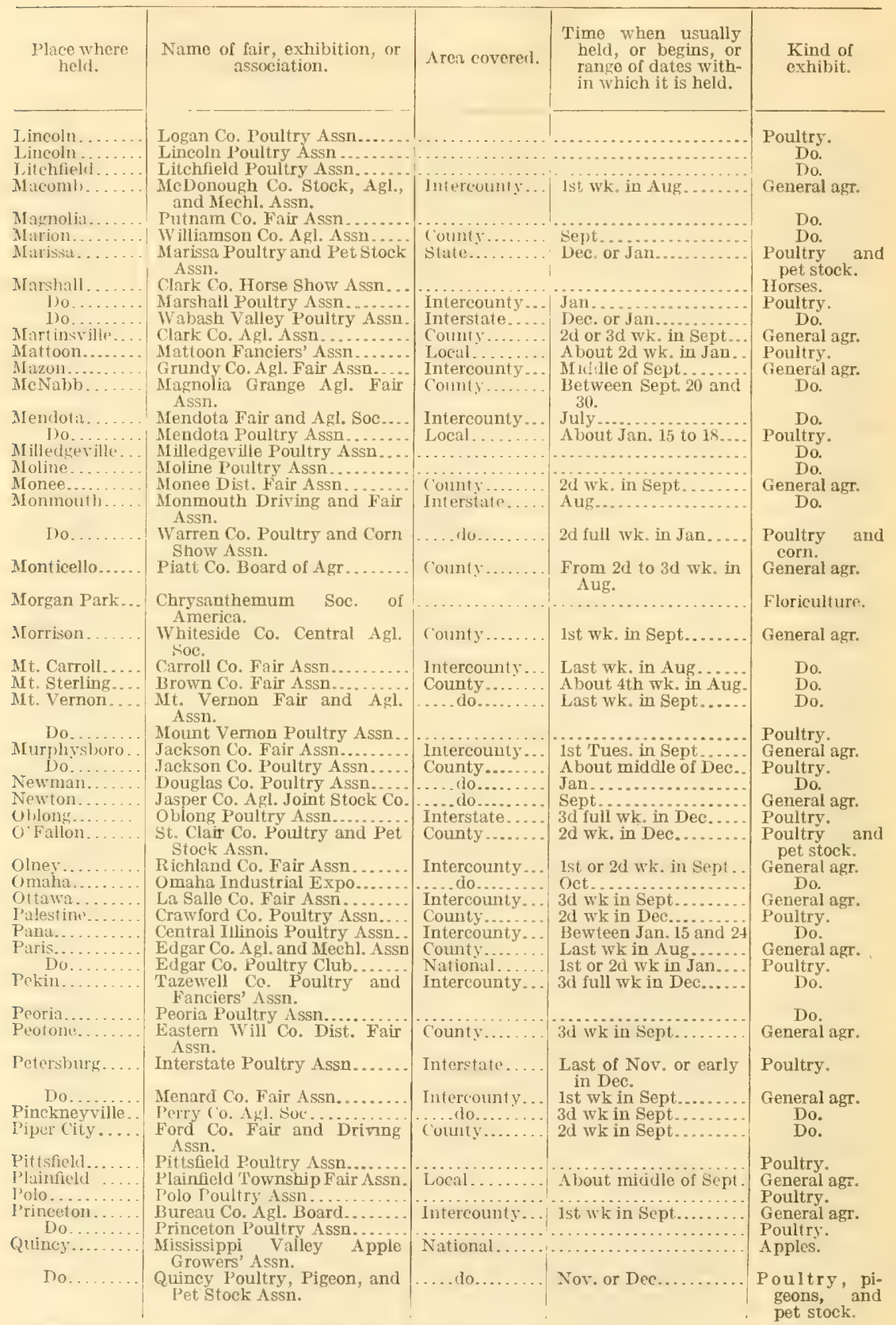

REQUEST.-It is requested that everybody who is able to do so will send to this department corrections of errors in this bulletin and additions to the list of fairs and exhibitions. 
TABLE 4,-List of fairs and cxhibitions devoted to agriculture, live stock, and other related subjects, by States, 1912-Continued.

ILLINOIS-Continued.

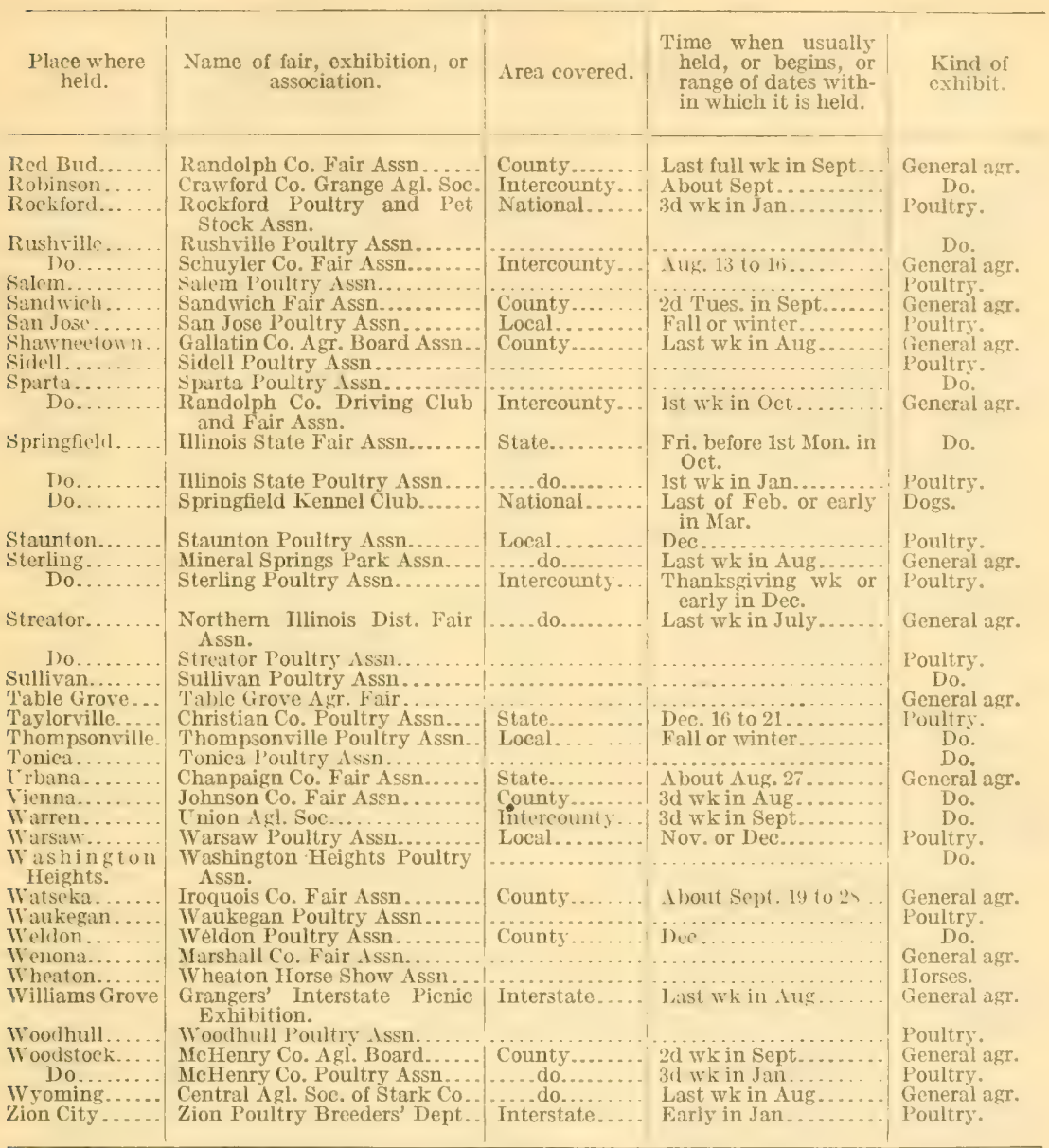

INDIANA.

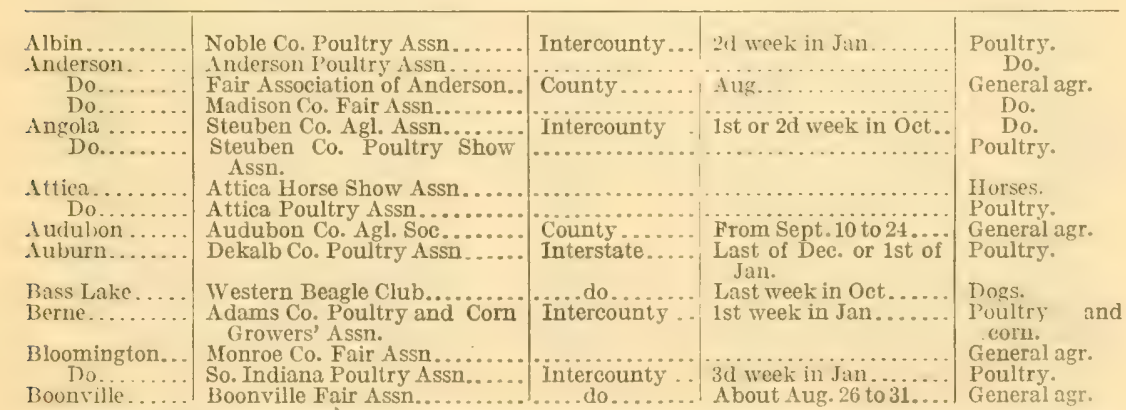

REQUEST.-It is requesteo that everybody who is able to do so will send to this department corrections of errors in this bulletin and additions to the list of fairs and exhibitions. $64267^{\circ}-13-4$ 
'T'ABLE 4.-List of fairs and exhibitions devoted to agriculture, live stock, and other related subjects, by States, 1912 -Continued.

INDIAN $\Lambda-$ Continued.

\begin{tabular}{|c|c|c|c|c|}
\hline $\begin{array}{l}\text { Place where } \\
\text { held. }\end{array}$ & $\begin{array}{c}\text { Name of fair, exhibition, or } \\
\text { association. }\end{array}$ & Area covered. & $\begin{array}{l}\text { Time when usually } \\
\text { held, or begins, or } \\
\text { range of dates with- } \\
\text { in which it is held. }\end{array}$ & $\begin{array}{l}\text { Kind of } \\
\text { exhibit. }\end{array}$ \\
\hline b & Bourbon Fair Assn.. & Intercounty & 1st week in Oct. & General agr. \\
\hline & Brazil Poultry Club. & Interstate... & $3 d$ week in Jan... & Poultry. \\
\hline & 13remen Agl. Assn.............. & County... & Sept. 24 to $27 \ldots$ & General agr. \\
\hline Chrisney. & Spencer Co. Fair Assn .......... & .... do... & Aug. and Sept... & Do. \\
\hline Columbus. & $\begin{array}{l}\text { American Poultry and Fan- } \\
\text { ciers }^{\prime} \text { Assn. }\end{array}$ & Local... & Jan. or Dec.......... & Poultry. \\
\hline Do & Bartholomew Co. Fair Assn... & Inte & $3 d$ week in Aug...... & General agr. \\
\hline Connersvi & Fayette Co. Free Fair Assn .... & County. & $\begin{array}{l}\text { Last week in Aug. or } \\
\text { 1st week in Sept. }\end{array}$ & Do. \\
\hline Converse & Miami Co. Agl. Assn ......... . & Intereounty... & $3 \mathrm{~d}$ week in Sept..... & Do. \\
\hline Do & Miami Co. Poultry Assn ..... & $\ldots . .$. & Dec...................... & Poultry. \\
\hline Coryd & Harison Co. Agl. Soc........ & Intercou & Last week in Aug.... & General agr. \\
\hline$\ldots . .$. & Covington Fair Assn.......... & ..... do. & 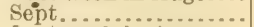 & Do. \\
\hline Crawfordsville. & $\begin{array}{l}\text { Montgomery Co. Union Agl. } \\
\text { Soc. }\end{array}$ & ..... do. & Last week in Aug..... & Do. \\
\hline Crothersville... & Crothersville Fair Assn . . . . . . & County. & Last of Aug. or 1st of & Do. \\
\hline Crown Point... & Lake Co. $\Lambda$ gl. Soc & & $A$ bout $3 d$ week in & ந)o. \\
\hline $\mathrm{Da}$ & Henricks Co. Fanciers' Assn ... & Inter & 3d full week in Jan.... & Poultry. \\
\hline Der & $\begin{array}{l}\text { Great Northern Indiana Fair } \\
\text { Assn. }\end{array}$ & Lor & During Sept...... & General agr. \\
\hline East Enterprise & East Enterprise Fair $\Lambda$ ssn... & Inte & 1st of $\mathrm{S}$ & Do. \\
\hline Edint & Edinburg Fair Assn... & $T=10$ & A bout July 17 to 19 & Do. \\
\hline Elkhar & Ell:hart Poultry Assn. & International . & $\begin{array}{l}\text { Week beginning last } \\
\text { Mon. in Jan. }\end{array}$ & l'oultry. \\
\hline & Elnora Poultry $\Lambda$ ssn & $\mathrm{Co}$ & 1st week in Jan... & Do. \\
\hline & $\begin{array}{l}\text { Elwood Driving Park and } \\
\text { Fair } \Lambda \text { ssn. }\end{array}$ & & $3 d$ week in Aug. & General agr. \\
\hline Evansvill & Ohio Valley Fanciers' Assn . . . . & Int & $2 d$ week in Jan & Poultry. \\
\hline Fi & Vanderburg Fair 1s & & $2 \mathrm{~d}$ & General agr. \\
\hline Far & Randolph Co, Poultry A ssn... & $\cdots$ & Jan & Poultry. \\
\hline Fra & Clinton Co. Fair Assn........... & Coul & A bout Aug. 13 . & General agr. \\
\hline Fra & $\begin{array}{l}\text { Johnson Co. Agl., Hort., and } \\
\text { Park Assn. }\end{array}$ & & $3 \mathrm{~d}$ week i & Do. \\
\hline & Johnson Co. Poultry Assn.... . & & $3 \mathrm{~d}$ week ir & Poultry. \\
\hline Fort W & Fort Wayne Fair Assn....... & & Sept. . & General agr. \\
\hline Do & Poultry Fanciers' Assn . . . . . . . & $\ldots$ & Jan & Poultry. \\
\hline Galve & Galveston $\mathrm{P}$ & Lo & $\begin{array}{l}\text { During holiday week } \\
\text { or 1st week in Jan. }\end{array}$ & Do. \\
\hline Gosher & Elkhart Fair Ass & & & General agr. \\
\hline & Ma & & Jar & Poultry. \\
\hline Greensbur & $\begin{array}{l}\text { Greensburg Breeders' and Fan- } \\
\text { ciers' Assn. }\end{array}$ & Intercour & Dec. or Jal & Do. \\
\hline & Greensburg Fair Assn........ . & & Last of July or 1st of & General agr. \\
\hline $\mathrm{Gr}$ & Greentown Poult & & & $\mathrm{Po}$ \\
\hline Hu & Dubois Co. Fair Assn. & $\mathrm{Co}$ & $2 d$ & General agr. \\
\hline Hunti & Huntington Co. Fair . . . . . . . . . & Int & 1st half of Sept. & Do. \\
\hline & $\begin{array}{l}\text { Huntington, Poultry, Pigeon } \\
\text { and Pet Stock Assn. }\end{array}$ & Inters & $2 \mathrm{~d}$ or $3 \mathrm{~d}$ week in Jan. & $\begin{array}{l}\text { Poultry, pi- } \\
\text { geons, and } \\
\text { pet stock. }\end{array}$ \\
\hline Indianapolis. & American Carnation & Natio & Last c & Floriculture \\
\hline & Indiana.... & Stat & 1 st week in Feb.. & Dogs. \\
\hline D & Int & $\cdots$ & Nor.. & Horticulture. \\
\hline $\mathrm{D}$ & $\begin{array}{l}\text { 1a State Fair Assn......... } \\
\text { nal Fanciers' Club. ...... }\end{array}$ & & Sept. & Gener \\
\hline Kem & on Fanciers' Club..... & Na & $\cdots$ & $\begin{array}{l}\text { Poultry. } \\
\text { Do. }\end{array}$ \\
\hline & Indiana Agl. Assn.... & Natio & Sept... & General agr. \\
\hline & Howard Co. Fanciers' Assn.. & inty.. & 1st or $2 d$ & Poult \\
\hline Lat F: & Tippecanoe Co. Agl. Assn. & Tntor & About Sept..... & General agr. \\
\hline & try Assn. & Interstate. & Jan .............. & Poultry. \\
\hline La Gr & La Grange Poultry Assn.. & & & \\
\hline La P & La Porte Co. Agl. Assn........ . & Co & Last wk. i & General agr. \\
\hline & La Porte Con Poultry Assn.... & National. & Last wk. in Jan $\ldots . .$. . & Poultry. \\
\hline Le & 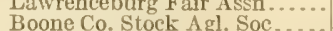 & $\begin{array}{l}\text { Interstate } \\
\text { Intercount }\end{array}$ & A bout 2 d wk. in Aug. & General agr. \\
\hline & Central Indiana Fanciers' Assn. & indo....... & A bout 2 d wk. in Jan... & Poultry. \\
\hline & Union Co. Fair $\Lambda$ ssn . ........... & & A bout Sept. 3 to $6 \ldots . .$. & General agr. \\
\hline ans 1 & $\begin{array}{l}\text { Logansport Fanciers' Club } \\
\text { (Inc.) }\end{array}$ & & Middle wk. in Jan.... . & Poultry. \\
\hline
\end{tabular}

REQUEST.-It is requested that everybody who is able to do so will send to this department corrections of errors in this bulletin and additions to the list of fairs and exlubitions. 
TABLE 4.-List of fairs and exhibitions devoted to agriculture, live stock, and other related subjects, by States, 1912-Continued.

INDIANA-Continued.

\begin{tabular}{|c|c|c|c|c|}
\hline $\begin{array}{l}\text { Place where } \\
\text { held. }\end{array}$ & $\begin{array}{l}\text { Name of fair, exhibition, or } \\
\text { association. }\end{array}$ & Area covered. & $\begin{array}{l}\text { Time when usually } \\
\text { held, or begins, or } \\
\text { range of dates with- } \\
\text { in which it is held. }\end{array}$ & $\begin{array}{l}\text { Kind of } \\
\text { exhibit. }\end{array}$ \\
\hline Lowell Poultry & L.owell Poultry Assn & & & Poultry \\
\hline Mareng & Crawford Co. Fair Assn.. & Intercoun & $3 \mathrm{~d}$ wk. in $\mathrm{Aug}$ & General agr. \\
\hline Marios & I3ig Marion Fair Assn .............. & National. & July........ & Do. \\
\hline Martins & $\begin{array}{l}\text { Martinsville Poultry and Pet } \\
\text { Stock Assn. }\end{array}$ & County.. & Jan..... & $\begin{array}{l}\text { Poultry and } \\
\text { pet stock. }\end{array}$ \\
\hline Michigan City.. & Great Lakes Poultry Assn..... & International. & Dec. and Jan... & Poultry. \\
\hline $\mathrm{Mi}$ & $\begin{array}{l}\text { Henry, Madison and Delaware } \\
\text { Co. Ágl. Soc. }\end{array}$ & Local. & 1st wk. in Aug. & General agr. \\
\hline Monrov & Monrovia Horse Show Assn... & & & Horses. \\
\hline Mc & $\begin{array}{l}\text { Montpelier Fair and Driving } \\
\text { Assn. }\end{array}$ & Count & A bout July 16 to 2 & General agr. \\
\hline lo & Newton Co. Poultry Assn..... & & Dec & Poultry. \\
\hline & Mulberry Poultry Ássn. & Local. & Ist wh. in Feb. or Mar. & Do. \\
\hline Mur & $\begin{array}{l}\text { Delaware Co. Agl. and Mechl. } \\
\text { Soc. }\end{array}$ & Count $y$. & $2 \mathrm{~d}$ wk. in $\mathrm{Aug} . . . . . .$. & General agr. \\
\hline 20 & Muncie Poultry Assn ......... & & & Poultry. \\
\hline app & Nappanee Poultry Assn... & Local. & Der. & Do. \\
\hline New Harmony. & $\begin{array}{l}\text { Henry Co. Agl. Assn } . . . . . . . . \\
\text { Poser (C. Agl. Soc . . . . . . }\end{array}$ & $\begin{array}{l}\text { State... } \\
\text { County }\end{array}$ & $2 \mathrm{~d}$ or $3 \mathrm{~d}$ wk. in Aug... & Gerieral agr. \\
\hline Noblesville.... & $\begin{array}{l}\text { Hamilton Co. Poultry and Pet } \\
\text { Stock Assn. }\end{array}$ & & & Poultry and \\
\hline $\begin{array}{l}\text { North Man- } \\
\text { chester. }\end{array}$ & $\begin{array}{l}\text { North Manchester Fair and } \\
\text { Racing Assn. }\end{array}$ & Intercounty. & Last wk. in Sept. & Gcreral agr \\
\hline North Vernon. & Jennings Co. Joint Stock Agl. & County. . & Wk. containing July 31 & Do. \\
\hline Osg & Ripley Co. Agl. Fair Assn..... & Intercounty. & 1st wh. in Aug. & Do. \\
\hline $\mathrm{Pa}$ & Patricksburg Poultry Assn.... & & & Poultry. \\
\hline Pine Village & Pine Village Fair Assn ........ & locul & Sept. & $\begin{array}{l}\text { General azr. } \\
\text { Do. }\end{array}$ \\
\hline Portlant & $\begin{array}{l}\text { A. H. and I. Joint Stock Com- } \\
\text { pany. }\end{array}$ & County... & $\begin{array}{l}\text { Last wk. in Aug. or } \\
\text { lst wk. in Sept. }\end{array}$ & Do. \\
\hline $\begin{array}{l}\text { Do } \\
\text { I'rinketuil }\end{array}$ & Eastern Indiana Poultry Assn. & $\begin{array}{l}\text { Inter } \\
\text { Intet }\end{array}$ & 2d wk. in & Poultry. \\
\hline & $\begin{array}{l}\text { Princeton Poultry and Pet } \\
\text { Stock Assn. }\end{array}$ & me. do. & $\begin{array}{l}\text { 1st Wk. in sept } \\
\text { Dec. or Jan.... }\end{array}$ & $\begin{array}{l}\text { General agr. } \\
\text { Poultry and } \\
\text { pet stock. }\end{array}$ \\
\hline Ineminertor & Pemington Horse Show Assn.. & & & IIorses. \\
\hline 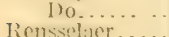 & Remington Poultry Assn...... & Natio & & Poultry. \\
\hline 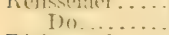 & $\begin{array}{l}\text { Rensselaer Horse Show Assn. - } \\
\text { Rensselaer Poultry Assn...... }\end{array}$ & & & $\begin{array}{l}\text { Porses. } \\
\text { Poultry. }\end{array}$ \\
\hline , & Richmond Poultry Assn ...... & & & Do. \\
\hline I & $\begin{array}{l}\text { Fulton Co. Agl. and Mechl. } \\
\text { Assn. }\end{array}$ & Col & 1st or $2 \mathrm{~d}$ i & General agr. \\
\hline Rock & Spencer Co. Fair Assn......... & .....d & $3 \mathrm{~d}$ wk. in & Do. \\
\hline & Rush Co. Fai & ... & $\mathrm{Ab}$ & Do. \\
\hline & $\begin{array}{l}\text { Silem Fair Asvn... } \\
\text { Sermour Poultry } A \text { s }\end{array}$ & ..... do & 1st full wk. in Sept.... & Do. \\
\hline $0 t t .1$ & Scott Co. Agl. Fair Assn....... & County. & Ain & $\begin{array}{l}\text { Poultry. } \\
\text { General agr. }\end{array}$ \\
\hline T) & $\begin{array}{l}\text { Scott Co. Poultry and Pet } \\
\text { Stock Assn. }\end{array}$ & Intercouit & A bout the holiday & Poultry and \\
\hline Shellyvill & $\begin{array}{l}\text { Shelby Co. Joint Stock Agl. } \\
\text { Assn. }\end{array}$ & County & $\begin{array}{l}\text { Begins 1st Tues. in } \\
\text { Sept. }\end{array}$ & General agr. \\
\hline$\underset{\text { erid }}{\mathrm{D}}$ & Shelbyville Poultry Assn.... . & & & Poul \\
\hline & Sheridan Poultry and Pet & Inter & About middle of Jan.. & $\begin{array}{l}\text { Horses. } \\
\text { Poultry and }\end{array}$ \\
\hline South Bend. & South Bend Poultry and Pet & Interstate & Dec. 26 to Jan. 1. & \\
\hline Sp & Spencer Poultry Assn. & Cou & Dec. or Jas & Poultry. \\
\hline & Sullivan Poultry Assn... & & & Do. \\
\hline & $\begin{array}{l}\text { Terre fraute Poultry } \text { issn } \\
\text { (Inc.) }\end{array}$ & & & Do \\
\hline I) & $\begin{array}{l}\text { Terre Haute Trotting and } \\
\text { Fair Assn. }\end{array}$ & do & $2 \mathrm{~d}$ w. in $\mathrm{Se}$ & General agr. \\
\hline rint & Tipton Poultry Assn... & & & Po \\
\hline & Porter Co. Fair Assn..... & C'o & Alug. $20 \mathrm{tc}$ & General agr. \\
\hline Vinces & $\begin{array}{l}\text { Valparaiso Poultry Assn...... } \\
\text { Knox Co. Agr. and Mechl. Soc. }\end{array}$ & & $\mathrm{Ab}$ & $\begin{array}{l}\text { Poultry. } \\
\text { General agr. }\end{array}$ \\
\hline Do & $\begin{array}{l}\text { Vincennes Poultry and Pet } \\
\text { Siock Assn. }\end{array}$ & In & Dec. or Jan.......... & $\begin{array}{l}\text { Poultry and } \\
\text { pet stock. }\end{array}$ \\
\hline & Elkhart Co. Fair Assn.......... & & & General agr. \\
\hline & $\begin{array}{l}\text { Warren Tri-Co. Fair and } \\
\text { Driving Assn. }\end{array}$ & Int & 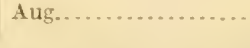 & $\mathrm{D}$ \\
\hline
\end{tabular}

REQUEST.-It is requested that everybody who is able to do so will send to this department corrections of errors in this bulletiu and additions to the list of fairs and exhihitions. 
TABLE 4.-List of fairs and exhibitions devoted to agriculture, live siock, and other related subjects, by States, 1912-Continued.

INDIANA-Continued.

\begin{tabular}{|c|c|c|c|c|}
\hline $\begin{array}{l}\text { Place where } \\
\text { held. }\end{array}$ & $\begin{array}{l}\text { Name of fair, exhibition, or } \\
\text { association. }\end{array}$ & Area covered. & $\begin{array}{l}\text { Time when usually } \\
\text { held, or begins, or } \\
\text { range of dates with- } \\
\text { in which it is held. }\end{array}$ & $\begin{array}{l}\text { Kind of } \\
\text { exhibit. }\end{array}$ \\
\hline Washington.... & White River Poultry and Pet & Intercounty... & Dec, or Jan... & \multirow{4}{*}{$\begin{array}{l}\text { Poultry and } \\
\text { pet stock. } \\
\text { Do. } \\
\text { General agr. } \\
\text { Poultry. }\end{array}$} \\
\hline West Point.... & $\begin{array}{l}\text { Lee Co. Poultry and Pet Stock } \\
\text { Assn. }\end{array}$ & Interstat & $\begin{array}{l}\text { Last of Dec. or early } \\
\text { in Jan. }\end{array}$ & \\
\hline $\begin{array}{l}\text { Wringate......... } \\
\text { Young America }\end{array}$ & 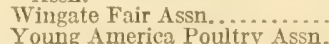 & & & \\
\hline Poung Alnericd & Young America Poultry Assn. & & 1st wk. in Jan... & \\
\hline
\end{tabular}

IOW A.

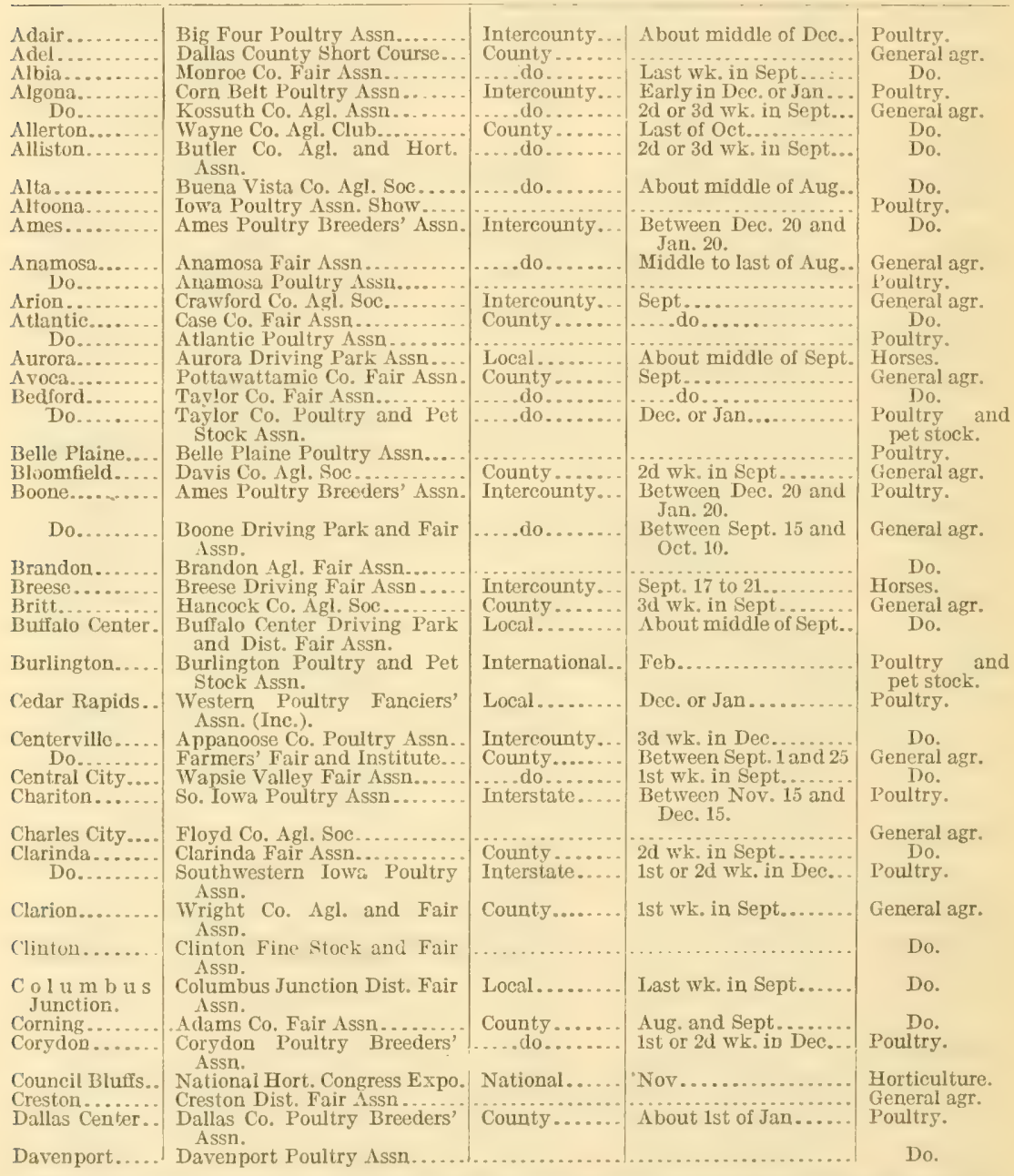

REQUEST.-It is requested that everybody who is able to do so will send to this department corrections of errors in this bulletin and additions to the list of fairs and exhibitions. 
TABLE 4.-List of fairs and exhibitions devoled to agriculture, live stock, and other related subjects, by States, 1912 -Continued.

IOWA-Continued.

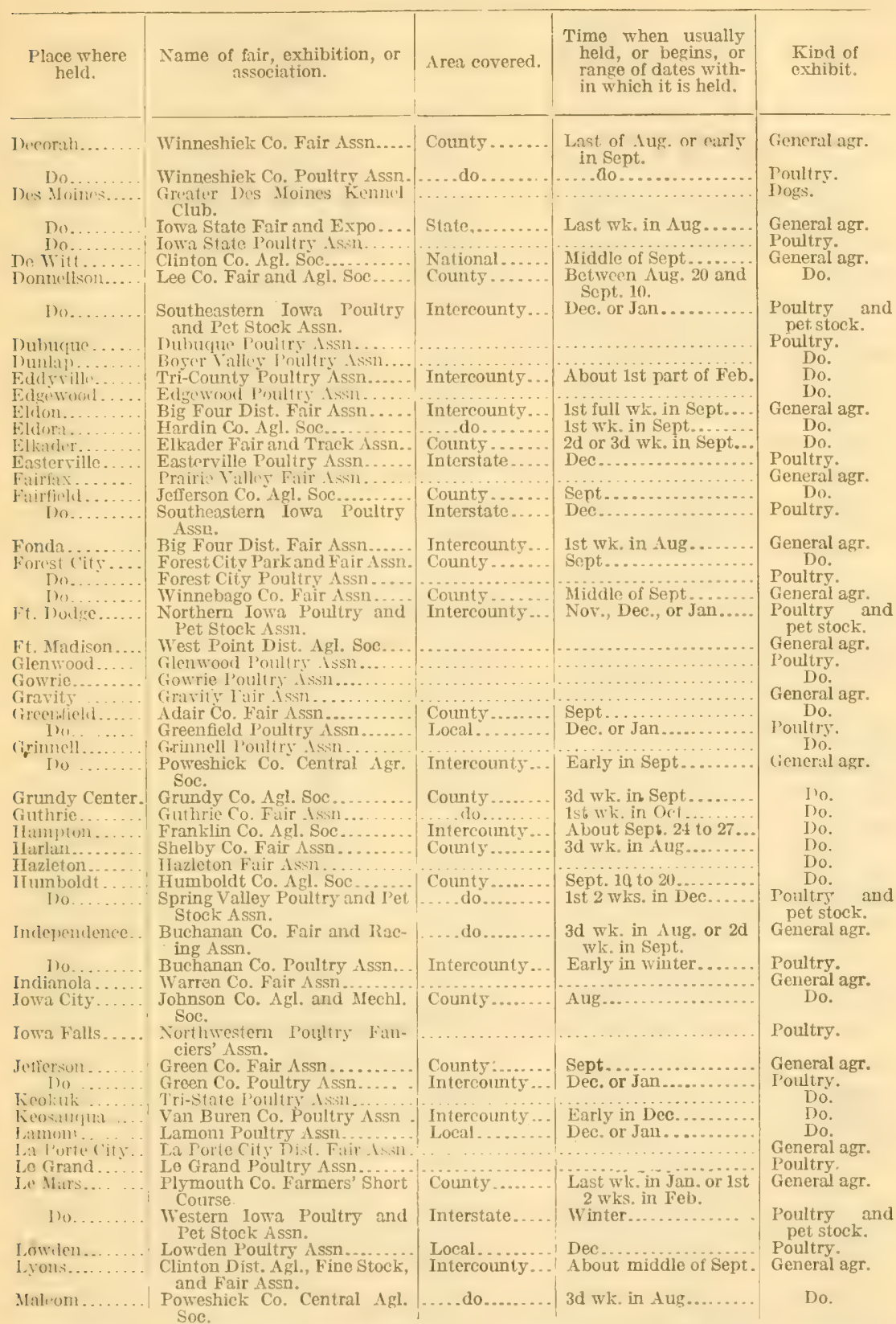

REQUEST. It is requested that everybody who is able to do so will send to tuis department corrections of errors in this bulletun and additions to the list of fairs and exhibitions. 
TABLE 4.- List of fairs and exhibitions devoted to agriculture, live stock, and other related subjects, by States, 1912 - Continued.

IOW A-Continued.

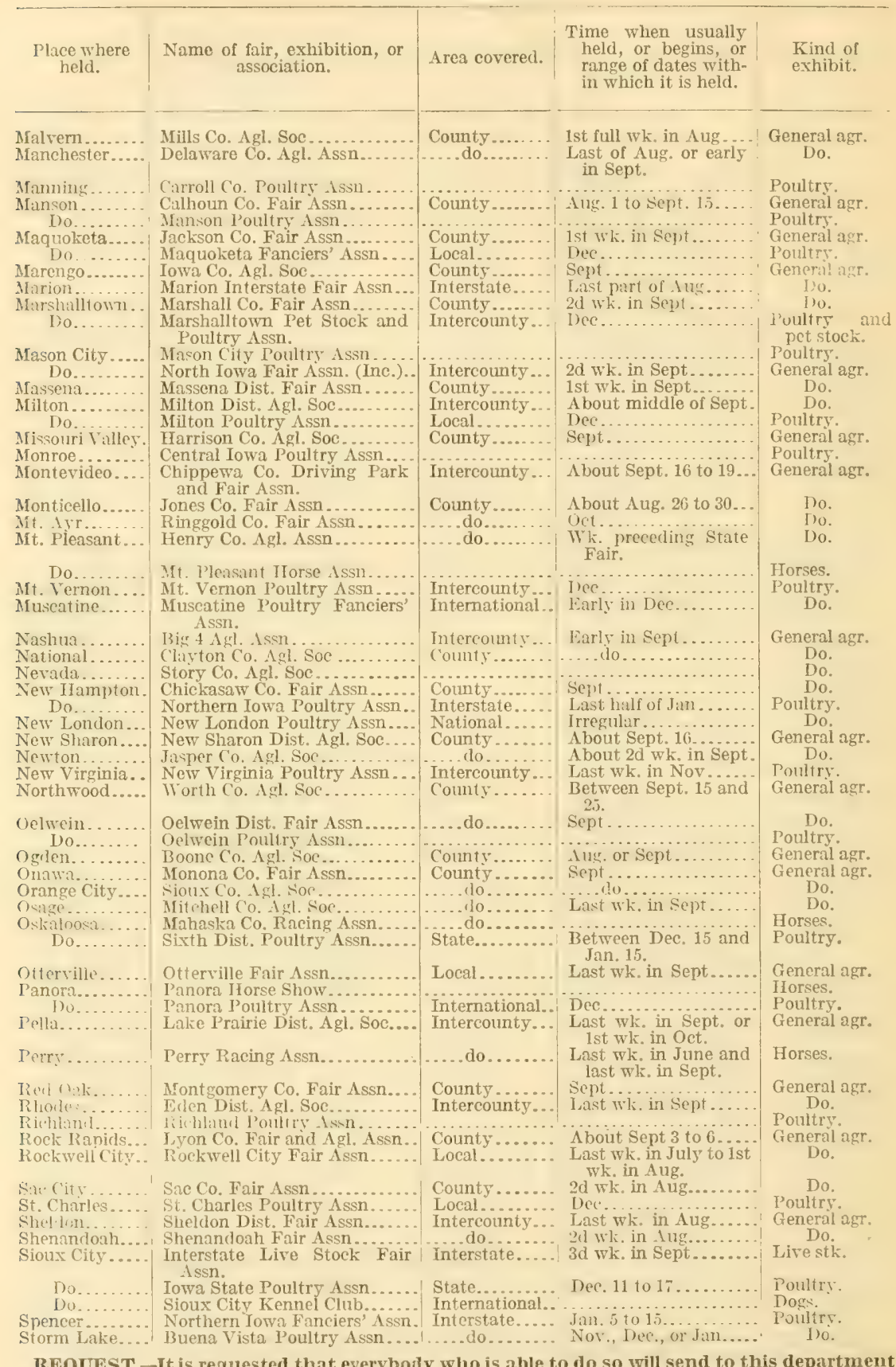

REQUEST.-It is requested that everybody who is able to do so will send to this department corrections of errors in this bulletin and additions to the list of fairs and exhibitions. 
TABLE 4.-List of fairs and exhibitions devoted to agriculture, live stock, and other related subjects, by States, 1912-Continued.

IOWA-Continued.

\begin{tabular}{|c|c|c|c|c|}
\hline $\begin{array}{l}\text { Place where } \\
\text { held. }\end{array}$ & $\begin{array}{c}\text { Name of fair, exhibition, or } \\
\text { association. }\end{array}$ & Area covered. & $\begin{array}{l}\text { Time when usually } \\
\text { held, or begins, or } \\
\text { range of dates witll- } \\
\text { in which it is held. }\end{array}$ & $\begin{array}{l}\text { Kind of } \\
\text { exhibit. }\end{array}$ \\
\hline Straw berry & Strawberry Point Dist. Fair & District.. & 1st full wk. in Sept... & General agr. \\
\hline Sutherland..... & O'Brien Co, Agl. Assn... & Count & 1.st wk. in siept.. & Do. \\
\hline 'insley... & Tinsley Fair Is.sn..... & & ..... do .......... & Do. \\
\hline Tiptur. - & Codar co. Fair Isn .......... & $I 0$ & 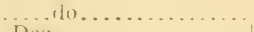 & Do. \\
\hline 1$) 0$. & $\begin{array}{l}\text { Cedar Co. Poultry Breeders' I } \\
\text { Assn. }\end{array}$ & Local & Pis & Poultry. \\
\hline Totedo. & Tama Co. Fair Assn......... & County..... & $3 d$ or 4 th $\pi k$. in Sept. . & General agr. \\
\hline$y_{i}$ & Victor Dist. Agl. Soc... & Interc & Middle of Aug.......... & Do. \\
\hline Tintor. & Benton Co. 1.s. Asin . . . . . . . & & $\begin{array}{l}\text { Between Sept. } 1 \text { and } \\
\text { 10. }\end{array}$ & Do. \\
\hline Do. & $\begin{array}{l}\text { Vinton Poultry and Pet Stock } \\
\text { Assn. }\end{array}$ & & $J_{i}: n \ldots \ldots$ & $\begin{array}{l}\text { Poultry and } \\
\text { pet stock. }\end{array}$ \\
\hline Wapello.. & Wapello Dist. Fair Assn.. & & & General agr. \\
\hline $\begin{array}{l}\text { Do. } \\
\text { IVaterlo }\end{array}$ & $\begin{array}{l}\text { Wapello Poultry Assn ..... } \\
\text { Iowa Dairy Cattle Congres: }\end{array}$ & & 2011 & $\begin{array}{l}\text { Poultry. } \\
\text { Dairying. }\end{array}$ \\
\hline Do... & Waterloo Poultry Assn... & & & Poultry. \\
\hline Waukon. & Allamakee Co. Agl. Soc. . & $\mathrm{C}$ & Last wh in Aug to & General agr. \\
\hline Waverly & Bremer Co. Fair Assn.. & unty... & $3 d$ week in Sept..... & Do. \\
\hline Webst & Hamilton Co. Fa & & $\begin{array}{l}\text { Last of Aug. or early } \\
\text { in Sept. }\end{array}$ & () \\
\hline West Liberty. . & Union Dist. Agl. Soc & Intercounty. & $3 \mathrm{~d}$ week in Aug... & Do. \\
\hline West $\mathrm{Po}$ & West Point Dist. Agl. So & & Sept. & Po. \\
\hline West Union... & Fayette Co. Agl. Assn ..... & $\mathrm{Co}$ & lit wh & Do. \\
\hline $\begin{array}{l}\text { What Chee } \\
\text { lvick. }\end{array}$ & What Cheer Dist. Fair Ass & & Sept. 23 to 26 .. & D) \\
\hline Williamsiourg - . & Williamsburg Pavilion and & Distric & Sept. 10 to $12 . . . . . . .$. & Do. \\
\hline Wilto & Wiiton Fair Assn .... & Inte & 30 wh. in 11 & Do. \\
\hline Winfiel & IVinfield Fair Assn....... & & Aug. 15.. & Do. \\
\hline & $\begin{array}{l}\text { WVinfield Pouttry and Corn } \\
\text { Assn. }\end{array}$ & & & $\begin{array}{l}\text { Poultry and } \\
\text { corn. }\end{array}$ \\
\hline Winter & Madison Co. Agl. Assn & Cou & About middle of Sept.. & General agr. \\
\hline
\end{tabular}

K.INSAS.

\begin{tabular}{|c|c|c|c|c|}
\hline Abilene. & Dickinson Co. Fair $\Lambda$ ssn..... & Count $\ldots . . . . .$. & Last of Sept. or early & General agr. \\
\hline Anthony. & Anthony Fair Assn........... & . . & 1st full wk. in Aug.... & Do. \\
\hline Arkansas...... & Arkansas City Poultry Assn... & & & Poultry. \\
\hline Belleville....... & Republic Co. Agl. Assn....... & County.. & 1st or $2 d$ wk. in Sept. & General agr. \\
\hline Beloit........... & Mitchell Co. Fair Assn.. & Intercounty... & 1st wk. in Oct......... & Do. \\
\hline $\begin{array}{l}\text { Burden......... } \\
\text { Burlingame.... }\end{array}$ & $\begin{array}{l}\text { Eastern Cowley Fair Assn..... } \\
\text { Osage Co. Fair Assn........... }\end{array}$ & .....do.......... & About Sept........... & Do. \\
\hline Burlington.... & Coffey Co. Agl. Fair Assn..... & Intercount & Sept. & Do. \\
\hline ('hanute....... & Four-Co. Dist. Agl. Soc....... & .... 110........ & 1st half of Sept & Do. \\
\hline Cherryvale..... & Cherryvale Poultry Club...... & $1-2=0$ & $\begin{array}{l}\text { Between middle of } \\
\text { Dec. and last of Tan. }\end{array}$ & Poultry. \\
\hline Cimarron....... & Gray Co. Agl. Soc..... & County.... & $3 d$ or 4 th wk. in Sept. & General agr. \\
\hline $\begin{array}{l}\text { Clay Center.... } \\
\text { Do }\end{array}$ & Clay Co. Fair Assn . . . . . . . . . & Intercounty... & sept 1 to $15 . \ldots \ldots \ldots$ & Do. \\
\hline r - - ilo & $\begin{array}{l}\text { North Central Kansas Poultry } \\
\text { Assn. }\end{array}$ & & to & 1 \\
\hline Coffeyrille:..... & Montgomery Co. Fair Assn.... & No & Last wh. in Sept..... & General agr. \\
\hline Concordia & Cloud Co. Fair Assn............. & $\begin{array}{l}\text { National. } \\
\text { State.... }\end{array}$ & $3 \mathrm{~d}$ w. in Sep & General agr. \\
\hline Dodge City..... & Dodge City Poultry Assn..... & & & Poultry. \\
\hline Do. & $\begin{array}{l}\text { Ford Co. Fair and Driving } \\
\text { Park } \Lambda \text { ssn. }\end{array}$ & & $\mid 20$ & General ag \\
\hline Douglass.. & Douglass Agl. Soc............. & County & Last wk. in Sept. or & Do. \\
\hline Effingham & Effingham Fair Assn.. & ..... do & Sept. or Oct....... & Do. \\
\hline El Dorado & Butler Co. Fair Assn..... & d] & About middle of Aug. & Do. \\
\hline $\begin{array}{l}\text { Do.. } \\
\text { Elsemore }\end{array}$ & Butler Co. Poultry Assn..... & & Dec & Poultry. \\
\hline Eureka..... & Greenwood Co. Fair Assn.... & Interstate & Ing. & Do. \\
\hline $\mathrm{Fr}$ & Frankfort Fair Assn. .......... & & & Do \\
\hline Fir $2+2$ & $\begin{array}{l}\text { Wilson Co. Poultry and Pet } \\
\text { Stock Assn. }\end{array}$ & & [ere or . Tat & $\begin{array}{l}\text { Poultry } \\
\text { pet stock. }\end{array}$ \\
\hline
\end{tabular}

REQUEST.-It is requested that everybody who is able to do so will send to this department corrections of errors in this bulletin and additions to the list of fairs and exhibitions. 
TABLE 4.-List of fairs and exhibitions devoted to agriculture, live stock, and other rclated subjects, by States, 1912-Continued.

KANSAS-Continued.

\begin{tabular}{|c|c|c|c|c|}
\hline $\begin{array}{l}\text { Place where } \\
\text { held. }\end{array}$ & $\begin{array}{c}\text { Name of fair, exhibition, or } \\
\text { association. }\end{array}$ & Area covered. & $\begin{array}{l}\text { Time when usually } \\
\text { held, or begins, or } \\
\text { range of dates with- } \\
\text { in which it is held. }\end{array}$ & $\begin{array}{l}\text { Kind of } \\
\text { exhibit. }\end{array}$ \\
\hline Goodland...... & $\begin{array}{l}\text { Sherman Co. Agl. and Racing } \\
\text { Assn. }\end{array}$ & County.. & $\begin{array}{l}\text { Last of Aug. or early } \\
\text { in Sept. }\end{array}$ & General agr. \\
\hline Great Bend.... & Barton Co. Fair Assn ......... & - & Sept. or Oct........... & Do. \\
\hline Greensburg.... & Kiowa Co. Poultry Assn..... & Intercounty... & A bout Dec. 14 to $17 \ldots$ & Poultry. \\
\hline Grenola........ & Elk Co. Agl. Fair Assn...... . & .... do......... & 1st wk. in Sept........ & General agr. \\
\hline Harper......... & Harper Co. Agl. Soc.......... . & Local ......... & Last wk. in sept...... & Do. \\
\hline $\begin{array}{l}\text { Highland Sta- } \\
\text { tion. }\end{array}$ & $\begin{array}{l}\text { Highland Station Pienie and } \\
\text { Fair Assn. }\end{array}$ & & & Do. \\
\hline IIolton......... & Tackson (o. Agl. Fair Issn... & & & Do. \\
\hline Hutchinson.... & & National....... & Sept... & $\begin{array}{l}\text { Do. } \\
\text { Poultry }\end{array}$ \\
\hline $\begin{array}{l}\text { Independence. . } \\
\text { Iola............ }\end{array}$ & 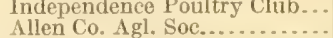 & $\begin{array}{l}\text { Interstate. } \\
\text { State...... }\end{array}$ & Aug. and Sept. & $\begin{array}{l}\text { Poultry. } \\
\text { General agr. }\end{array}$ \\
\hline Jetmore....... & $\begin{array}{l}\text { Hodgeman Co. Agl. Fair Stock } \\
\text { Assu. }\end{array}$ & County........ & 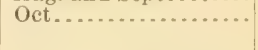 & Do. \\
\hline Kingman & $\begin{array}{l}\text { Kingman ('o. Driving I'ark } \\
\text { and Fair Assn. }\end{array}$ & & & Do. \\
\hline La Harpe & Farmers' Exhibit Assn........ & Lo & Sept. or & Do. \\
\hline Jalliled. & P'iwnee Co. Agr. Assn... & & Sept... & Do. \\
\hline $\begin{array}{c}\text { Leavenworth .. } \\
\text { Do }\end{array}$ & Leavenworth Co. Fair Assn... & Intercounty... & 1st wk. in Sept........ & $\begin{array}{l}\text { Do. } \\
\text { Jigeons. }\end{array}$ \\
\hline Do............. & Leavenworth Poultry Assn.... & County........ & 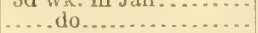 & Poultry. \\
\hline I. oni $i$ l)u & Louisturg Fair Asin .......... & & & General agr. \\
\hline Marysvi & Marshall Co. Fair Assn. - & County & Sept & Do. \\
\hline McPherson. & MePherson Co. Agl. Fair Assn. & .... do. & 1st wk. in Sept. & Do. \\
\hline Arelbour & $\begin{array}{l}\text { Newport Driving and Fair } \\
\text { Assn. }\end{array}$ & Inte & About Sept. 19 to & Do. \\
\hline Minneapolis.... & Ottawa Co. Fair Assn........ & & Last wh. in Sept & Do. \\
\hline Moran. & Moran Agl. Fair Assn ......... & Local ......... . & A bout middle of Sept. & Do. \\
\hline $\begin{array}{l}\text { Newton. } \\
\text { Norton.. }\end{array}$ & $\begin{array}{l}\text { Central Kansas Poultry Assn.. } \\
\text { Norton Co. } \Lambda \text { gl. Assn........ }\end{array}$ & $\begin{array}{l}\text { Intercounty... } \\
\text { County........ }\end{array}$ & $\begin{array}{l}\text { a full wk. in Dec..... } \\
\text { Last wk. in Aug..... }\end{array}$ & General agr. \\
\hline Do. & Norton Co. Poultry Assn..... & Intercounty... & 1 t or $2 \mathrm{~d} w \mathrm{w}$, in Dec.... & Poultry. \\
\hline Mound City & Linn Co. Fair Assn...... & County.. & $\begin{array}{l}\text { Last of Sept. or early } \\
\text { in Oct. }\end{array}$ & General agr. \\
\hline Yins Cit & Jess $C^{\circ}$ o. Agl, . Issn & $d$ & 1st hislf of Sept.. & \\
\hline Oakley & Inter-Co. Fair Ass & Intercou & Last wk. in Sept & Do. \\
\hline & Unagia Fair Assn... & Local & Sept. $20 .$. & Do. \\
\hline Ott & Franklin Co. Agl. Soc. & Intercou & Last of Sept.... & $\begin{array}{l}\text { Do. } \\
\text { Ponltry. }\end{array}$ \\
\hline I'ittsburg & Pittsburg Poultry Assn. & Local & $2 \mathrm{~d}$ or $3 \mathrm{~d}$ wh in Dec. & Do. \\
\hline & $\begin{array}{l}\text { Pratt Co. Fair Assn ........... } \\
\text { Pratt Putiltry Issn .......... }\end{array}$ & County. & Aug....... & $\begin{array}{l}\text { General agr. } \\
\text { Poultry. }\end{array}$ \\
\hline lichmond. & $\begin{array}{l}\text { Farmers and Mecbanics Fair } \\
\text { Assn. }\end{array}$ & & & General agr. \\
\hline ri & $\begin{array}{l}\text { Riley Fair Issn.............. } \\
\text { Jolf River Valles Fair Assn }\end{array}$ & & ind & $\begin{array}{l}\text { Do. } \\
\text { Do. }\end{array}$ \\
\hline & Won fiver raney far Assi. & & 20. & \\
\hline Rush Center... & Rush Co. Fair and Agl. $\Lambda$ ssn .. & County & Last wk. in Aug. & General agr. \\
\hline $\begin{array}{l}\text { St. John. } \\
\text { St. Marys. }\end{array}$ & $\begin{array}{l}\text { Statiord Co. Fair Assn . . . . . . } \\
\text { St. Marys Racing Assn..... }\end{array}$ & Local..... & $\begin{array}{l}\text { Uct. } 1 \text { to } 15 . . . . . . \\
3 \mathrm{~d} \text { wk. in } \mathrm{Aug} . . .\end{array}$ & $\begin{array}{l}\text { Do. } \\
\text { Horses. }\end{array}$ \\
\hline Saline... & $\begin{array}{l}\text { Saline Co. Agl., Hort., and } \\
\text { Mechl. Assn. }\end{array}$ & County.... & $\begin{array}{l}\text { Between Aug. } 24 \text { and } \\
\text { Sept. } 10 .\end{array}$ & General agr. \\
\hline Siell & Selden District Fair Assn . & & & $\begin{array}{l}\text { Do. } \\
\text { Do. }\end{array}$ \\
\hline Sent & Memaha Fair Assn.... & 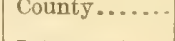 & $\begin{array}{l}\text { Last of Sept. or early } \\
\text { in Oct. }\end{array}$ & \\
\hline h Center.. & Smith Co. Fair Assn....... & Intercounty... & A bout Sept. 3 to $6 .$. & Do. \\
\hline & Sparks Pienic and Fair Assn. & County & Middle of Aug. & Do. \\
\hline Stockto & Rooks Co. Fair Assn ........... & .... do... & Ist wk. in Sept.... & Do. \\
\hline Sylvan & $\begin{array}{l}\text { Sylvan Grove Fair and Agl. } \\
\text { Assn. }\end{array}$ & do & $\begin{array}{l}\text { Between Sept. } 10 \text { and } \\
19 .\end{array}$ & Do. \\
\hline Topek & Kansas State Fair Assn. & St & 2d wk, in Sept.. & $\begin{aligned} \text { Do } & \\
\text { Poultr } & -1\end{aligned}$ \\
\hline & Topeka Poultry Assn.. & Na & ist wk. in Dee. & $\begin{array}{l}\text { Poultry. } \\
\text { General agr. }\end{array}$ \\
\hline Tribl & Topera show Assn... & & & Do. \\
\hline $\mathrm{U}$ & Udall Fair Assn.... & & & Do. \\
\hline Wakefie & Wakefield Agl. $\Lambda$ ssn.......... & LoC & 1st wk. in & Do. \\
\hline & Pottawatomie Co. Agl. Soc.... & County & Last part of Aug. & Do. \\
\hline & $\begin{array}{l}\text { Wichita and Southwestern } \\
\text { Fair Assn. }\end{array}$ & - & & Do. \\
\hline Winfield & $\begin{array}{l}\text { Cowley Co. Agl. and Live } \\
\text { Stock Assn. }\end{array}$ & County & About Sept & Do. \\
\hline
\end{tabular}

REOUEST.-It is requested that everybody who is able to do so will send to this department corrections of errors in this bulletin and additions to the list of fairs and exhibitions. 
TABLE 4.-List of fairs and exhibitions devoted to agriculture, live stock, and other related subjects, by States, 1912-Continued.

\section{KENTUCKY.}

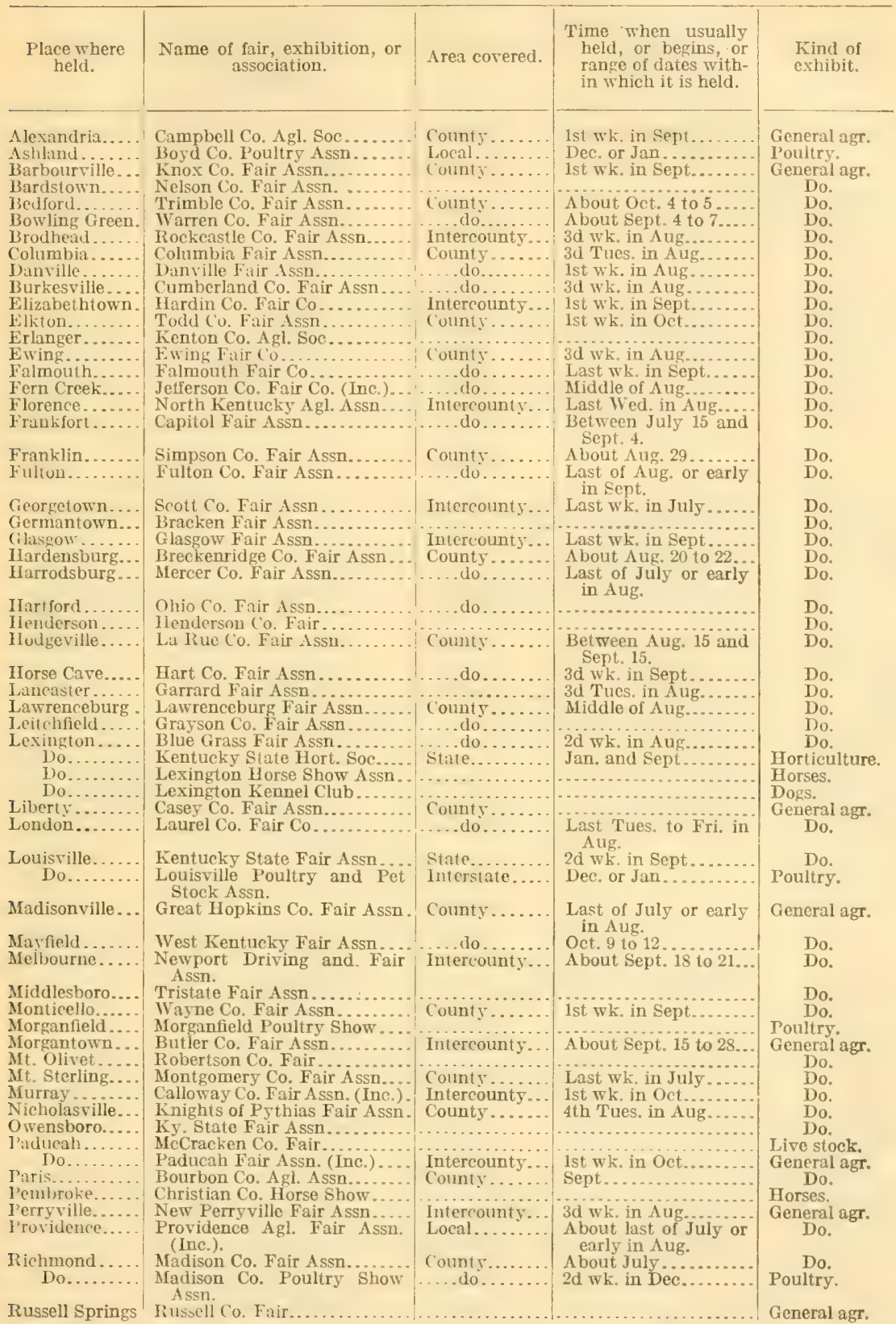

REQUEST.-It is requested that everybody who is able to do so will send to this department corrections of errors in this bulletin and additions to the list of fairs and exhibitions. 
TABLE 4.-List of fairs and exhibitions aevoted to agriculture, live stock, and other related subjects, by States, 1912 -Continued.

KENTUCKY-Continued.

\begin{tabular}{|c|c|c|c|c|}
\hline $\begin{array}{l}\text { Place where } \\
\text { held. }\end{array}$ & $\begin{array}{l}\text { Name of fair, exhibition, or } \\
\text { association. }\end{array}$ & Area covered. & $\begin{array}{l}\text { Time when usually } \\
\text { held, or begins, or } \\
\text { range of dates with- } \\
\text { in which it is held. }\end{array}$ & $\begin{array}{l}\text { Kind of } \\
\text { exhibit. }\end{array}$ \\
\hline Sanders. & Carroll Gallatin Owen Tri-Co. & County & 1st or $2 \mathrm{~d}$ wk. in Sept... & General agr. \\
\hline Scottville. & Allen Co. Fair Assn... & $d$ & Thurs. before $3 \mathrm{~d}$ MIon. & Do. \\
\hline Shelbyville & National Jersey Show. & & l. & Live stock \\
\hline $\begin{array}{l}\text { Shelbyville } \\
\text { Shepherds }\end{array}$ & Shelby Co. Fair & & & General Agr. \\
\hline Somerset. & Somerset Fair Assn. & & Last of Aug. or early & Do. \\
\hline Stanford & Stanford Fair Assn. & & & Do. \\
\hline & Washington Co. Fair Ass & County. & About Aug. 25. & \\
\hline & r Co. Fair As & Intercounty. & Middle of Au & \\
\hline Tompkinsville & Tompkinsville Fair Assn & County..... & 1st wk. in Sept. & Do. \\
\hline $\begin{array}{l}\text { Vane } \\
\text { Unio }\end{array}$ & $\begin{array}{l}\text { Vanceburg Fair Assn. } \\
\text { Union Co. Fair Assn. }\end{array}$ & ..... do. & Aug................. & Do. \\
\hline $\begin{array}{l}\text { Uniontown } \\
\text { Yersailles .. }\end{array}$ & $\begin{array}{l}\text { Union Co. Fair Assn } \\
\text { Knights of Pythias Fair Assn. }\end{array}$ & …...do. & $\begin{array}{l}2 \mathrm{~d} \text { wh. in Aug.......... } \\
\text { 1st wk. in Aug. }\end{array}$ & Do. \\
\hline Winchester. & Winchester Poultry Assn..... & & & Poultry. \\
\hline
\end{tabular}

\section{LOUISIANA.}

\begin{tabular}{|c|c|}
\hline Arcadia. & Bienville Parish Fair Assn. \\
\hline Beaux Bridge. . & St. Martin Parish Fair Ass \\
\hline Glinton........ & East Feliciana Fair Assn.. \\
\hline Homer. . & Claiborne Parish Fair Assn. \\
\hline Jennings & Jennings Poultry Assn ..... \\
\hline Lake Cha & Calcasieu-Louisiana Fair Ass \\
\hline Do. & $\begin{array}{l}\text { Calcasieu Poultry and Pe } \\
\text { Stock Assn. }\end{array}$ \\
\hline $\begin{array}{l}\text { Lake Provi- } \\
\text { dence. }\end{array}$ & East Carroll Fair Assn..... \\
\hline Leesville. & Vernon Parish Fair Assn. \\
\hline Marksvill & Avoyelles Parish Fair Assn \\
\hline Minden. & Webster Parish Fair Assn.. \\
\hline Mo & Monroe Poultry Assn ....... \\
\hline $\mathrm{Na}$ & $\begin{array}{l}\text { Natchitoches Parish Fair Ass } \\
\text { (Ltd.). }\end{array}$ \\
\hline New Orles & La. Poultry Fanciers' Assn \\
\hline Plain Deal & Bossier Parish Fair Assn... \\
\hline $\begin{array}{l}\text { Beott. } \\
\text { Shreve }\end{array}$ & Lafayette Fair Assn.... \\
\hline & State Fair Assn \\
\hline
\end{tabular}

\begin{tabular}{|c|c|c|}
\hline 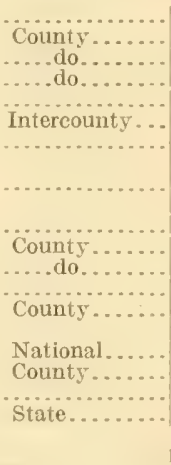 & 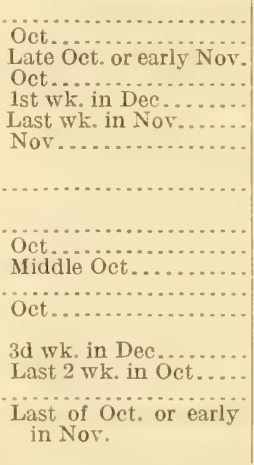 & $\begin{array}{l}\text { General Agr. } \\
\text { Do. } \\
\text { Do. } \\
\text { Do. } \\
\text { Poultry. } \\
\text { General Agr. } \\
\text { Poultry and } \\
\text { pet stock. } \\
\text { General Agr. } \\
\text { Do. } \\
\text { Do. } \\
\text { Do. } \\
\text { Poultry. } \\
\text { General Agr. } \\
\text { Poultry. } \\
\text { General Agr. } \\
\text { Do. } \\
\text { Do. }\end{array}$ \\
\hline
\end{tabular}

MAINE.

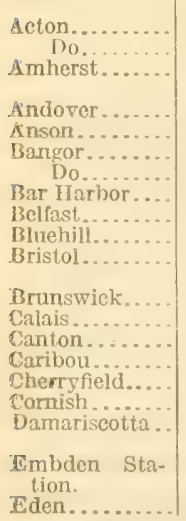

Shapleigh and $\Lambda$ cton Agl. Assn Union Park Assn Northern Hancock Agl. Soc.

Oxford North Agl. Soc. Somerset $\mathbf{A g l}$. Soc.

Bangor Poultry Assn. Eastern Maine State Fair Assn Bar Harbor Horse Show Assn Waldo Co. Agl. Soc . .......... Hancock Co. Agl. Soc....... Bristol Agl. Soc.

Freeport Poultry Assn. .

Calais Fair Assn

Androscoggin Valley Agl. Soc

Caribou Grange Fair Assn... West Washington $\mathrm{Agl}$. Soc.. Cornish Agl. Assn.

Lincoln Co. Fair Assn .......

Embden $\Lambda$ gl. $\Lambda$ ssn ..........

Eden Agl. Soc

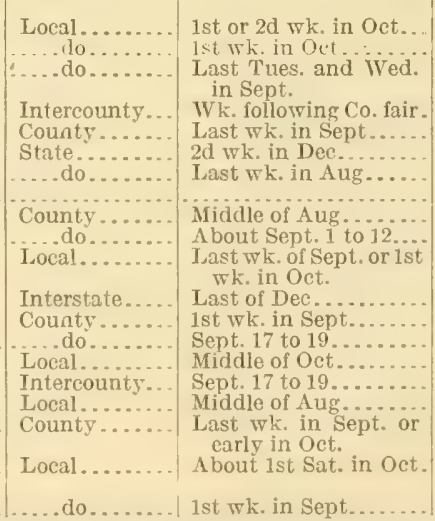

General agr.

Do.

Do.

Do.

Do.

Poultry

General agr.

Horses.

General agr.

Do.

Do.

Poultry.

General agr.

Do.

Do.

Do.

Do.

Do.

Do.

Do.

REOUEST.-It is requested that everybody who is able to do so will send to this department corrections of errors in this bulletin and additions to the list of fairs and exhibitions. 
TABLE 4.-List of fairs and exhibitions devoted to agriculture, live stock, and other related subjects, by States, 1912-Continued.

MAINE-Continued.

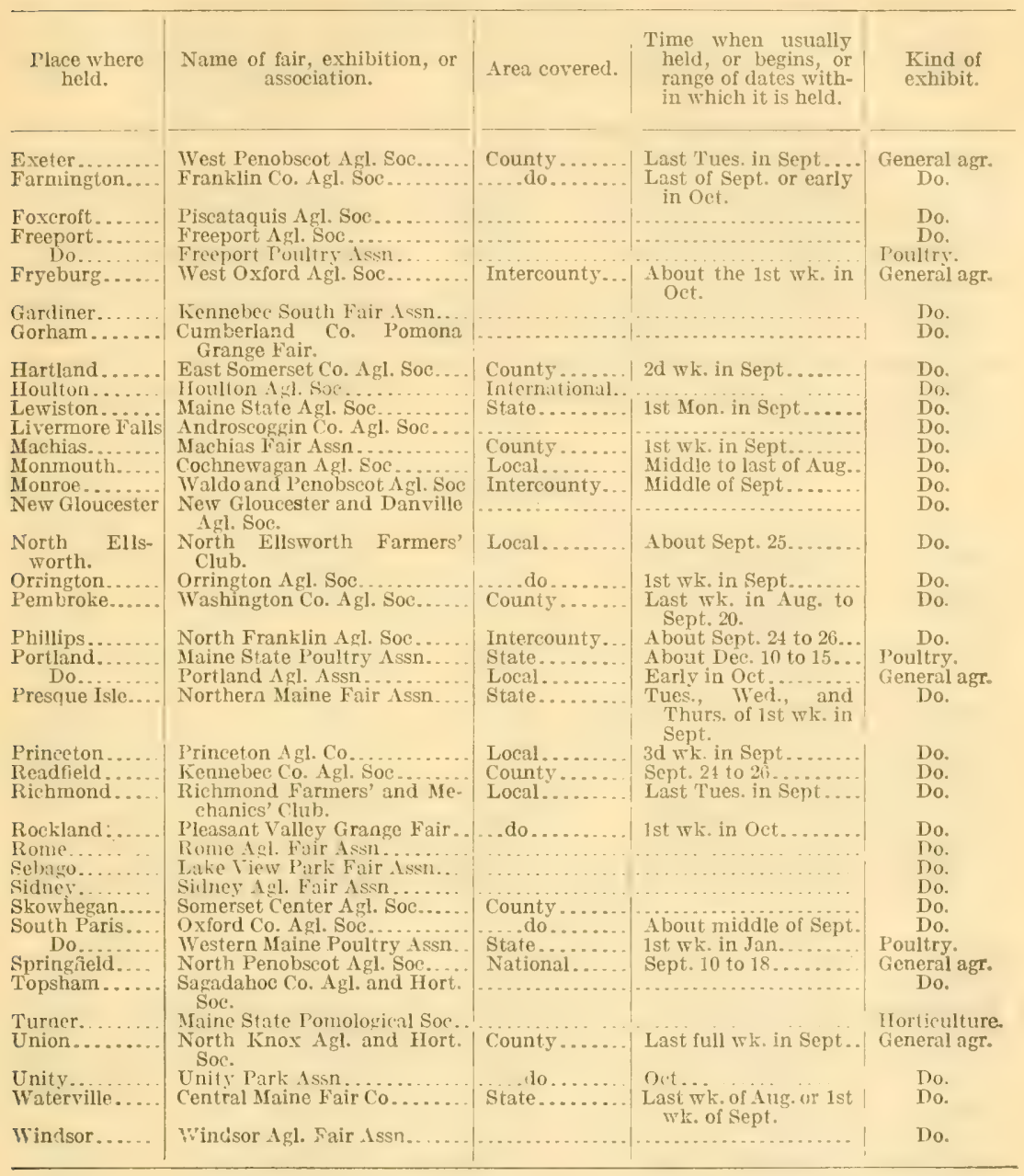

MARYLAND.

\begin{tabular}{|c|c|c|c|c|}
\hline Baltimore. & $\begin{array}{l}\text { Elkridge Hunt Club Horse } \\
\text { Show Assn. }\end{array}$ & Interstate. & Last part of May. & Horses. \\
\hline & $\begin{array}{l}\text { Maryland Poultry and Pigeon } \\
\text { Assn. }\end{array}$ & do & 1st wk. in Jan.. & $\begin{array}{l}\text { Poultry and } \\
\text { pigeons. }\end{array}$ \\
\hline Do & Maryland State Hort. Soc..... & State. & Nov. 18 to 23 & Horticulture. \\
\hline Bel Ai & $\begin{array}{l}\text { Harford Poultry and Pigeon } \\
\text { Assn. (Inc.). }\end{array}$ & International & A bout middle of Jan.. & $\begin{array}{l}\text { Poultry and } \\
\text { pigeons. }\end{array}$ \\
\hline Eastor & Talbot Co. Fair Assn. & Count & Last of Au & General agr. \\
\hline Frederi & Frederick Co. $\Lambda \mathrm{gl}$. Soc. & do & $3 d \mathrm{wk}$. in Oct. & Do. \\
\hline Hagerstow & $\begin{array}{l}\text { A gl. and Mechl. Assn of Wash- } \\
\text { ington Co. }\end{array}$ & Interstate & $\begin{array}{l}\text { 2d Tues. after Ist Mon. } \\
\text { in Oet. }\end{array}$ & Do. \\
\hline Hichla & II ichland IIorse Show Asen. & & & IIorses. \\
\hline Laurel... & Four Co. Fair Assn .............. & & & General agr. \\
\hline Lonaconin & $\begin{array}{l}\text { Allegany and Garrett Co. Agl. } \\
\text { Soc. }\end{array}$ & Intercounty & Last of Oct... & Do. \\
\hline
\end{tabular}

REQUEST.-It is requested that everybody who is able to do so will send to this department corrections of errors in this bulletin and additions to the list of fairs and exhibitions. 
TABLE 4.-List of fairs and exhibitions devoted to agriculture, live stock, and other related subjects, by States, 1912-Continued.

MARYLAND-Continued.

\begin{tabular}{|c|c|c|c|c|}
\hline $\begin{array}{l}\text { Place where } \\
\text { held. }\end{array}$ & $\begin{array}{c}\text { Name of fair, exhibition, or } \\
\text { association. }\end{array}$ & Area covered. & $\begin{array}{l}\text { Time when usually } \\
\text { held, or begins, or } \\
\text { range of dates with- } \\
\text { in which it is held. }\end{array}$ & $\begin{array}{l}\text { Kind of } \\
\text { exhibit. }\end{array}$ \\
\hline $\begin{array}{l}\text { Lonaconing.... } \\
\text { Pocomoke...... } \\
\text { Rocktille..... } \\
\text { Salisbury ..... } \\
\text { Taney town... } \\
\text { Timonium..... } \\
\text { Tolchester...... } \\
\text { Upper M a r 1. } \\
\text { boro. } \\
\text { West River.... }\end{array}$ & $\begin{array}{l}\text { Western Maryland Poultry. } \\
\text { Assn. } \\
\text { Pocomoke Fair and Agl. Assn. } \\
\text { A Sl. Soc. of Montgomery Co... } \\
\text { Wicomico Fair Assn........ } \\
\text { Maryland State Grange Fair } \\
\text { Assn. } \\
\text { Maryland State Fair and Agr. } \\
\text { Soc. of Baltimore Co. } \\
\text { Kent and Queen Annes Fair } \\
\text { Assn. } \\
\text { Southern Maryland Fair Assn. } \\
\text { Southern Maryland Colt Shom } \\
\text { Assn. }\end{array}$ & $\begin{array}{l}\text { Interstate.... } \\
\text { Intercounty... } \\
\text { County ....... } \\
\text { State............ } \\
\ldots . . \text { do ......... } \\
\text { Intercounty... }\end{array}$ & $\begin{array}{l}\text { Alout 1st wk. in Aug. } \\
\text { Last wk. in Aug ..... } \\
\text { 2d or } 3 d \text { wk. in Aug... } \\
\text { 2d wh. in Aug........ } \\
\text { 1st wh. in Sept......... } \\
\text { Aug.................... }\end{array}$ & $\begin{array}{l}\text { Poultry. } \\
\text { General agr. } \\
\text { Do. } \\
\text { Do. } \\
\text { Do. } \\
\text { Do. } \\
\text { Do. } \\
\text { Do. } \\
\text { Horses. }\end{array}$ \\
\hline
\end{tabular}

MASSACHUSETTS.

\begin{tabular}{|c|c|c|c|c|}
\hline Amestury... & Amesbury and Salisbury Agl. & County & Tues. after 1st Mon. in & General agr. \\
\hline Amlietst & Hampshire $\mathrm{Agl}$. Soc.. & Intercounty & A bout Sept. 25. & Do. \\
\hline At & $\begin{array}{l}\text { Worcester Northwest Agl. and } \\
\text { Mfechl. Soc. }\end{array}$ & Internationa & 1st wh. in Sept.. & Do. \\
\hline Anburnizle.. & Ladies' Kennel Assn. (Inc.)... & Satio & 1st wk. in Jur & Dogs. \\
\hline Burre & Worcester Co. Wiest Agl. & Le & $\begin{array}{l}\text { Last Thurs. and Fri. } \\
\text { in Sept. }\end{array}$ & General agr. \\
\hline B .nstab & Barnstahle Co. Agl. Soc...... & County & Aug................... & Do. \\
\hline Bedfo & American Asin. of Nirsery & & & Horticulture. \\
\hline $\begin{array}{l}\text { Blanford. } \\
\text { Beleherter }\end{array}$ & $\begin{array}{l}\text { 'nim Hort. and . 1.1. Sole.... } \\
\text { Belchertown Farmers' and }\end{array}$ & Inter & & General agr. \\
\hline & $\begin{array}{l}\text { Belchertown Farmers and } \\
\text { Mechanies' Club. }\end{array}$ & inter & Palmer, Mass. & Do. \\
\hline Boston.. & Boston Poultry Assn... & Internatic & $2 \mathrm{~d}$ wh. in Jan........ & Poultry. \\
\hline Do & $\begin{array}{l}\text { Boston Terrier Club.... } \\
\text { Eastern Dog Club...... }\end{array}$ & $\begin{array}{l}\text { Natic } \\
\ldots . . . d\end{array}$ & 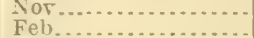 & Dogs. \\
\hline Do & IÍassachusetts Hort. Soc..... & In & Monthls. & Horticulture \\
\hline I) & $\begin{array}{l}\text { New England Fruit Show } \\
\text { (Inc.). }\end{array}$ & & $\begin{array}{l}\text { Last wk. in Oct. every } \\
2 \mathrm{~d} \text { year. }\end{array}$ & Do. \\
\hline $\mathrm{r}$ & New England Kennel Club... & Lor & Irregular.. & Dogs. \\
\hline & ntom 1.r. sec. & & Oct . & General agr. \\
\hline Cli & $\begin{array}{l}\text { Deerfield Valley Agl. Soc...... } \\
\text { Worcester East Agl. Soc....... }\end{array}$ & $\begin{array}{l}\mathrm{Co} \\
\mathrm{Lc}\end{array}$ & $\begin{array}{l}\text { Sep } \\
2 \mathrm{~d}\end{array}$ & Do. \\
\hline Cummington. & Hillsite . 1el. Assn ............ & $\mathrm{Cu}$ & Last Tues. and Wed. & Do. \\
\hline Lialton. & $\begin{array}{l}\text { Dalton Poultrs, Pigeon, and } \\
\text { Pet Stock Assn. }\end{array}$ & International.. & $2 \mathrm{~d} w \mathrm{k}$. in Jan & $\begin{array}{l}\text { Poultry, pi- } \\
\text { geons, and } \\
\text { pet stock. }\end{array}$ \\
\hline Framingham. & Framingham Dist. Kennel & Intercounts. & Irregular. & Dogs. \\
\hline Do......... & Middlesex South Agl. So & Cot & $3 \mathrm{~d} \pi \mathrm{k}$. in & General agr. \\
\hline $\begin{array}{l}\text { Great Barring- } \\
\text { ton. }\end{array}$ & Housatonic Agl. Soc... & & fth & Do. \\
\hline $\begin{array}{l}\text { Greenfield. } \\
\text { Do..... }\end{array}$ & $\begin{array}{l}\text { Franklin Co. Agl. Soc. } \\
\text { Greenfield Poultry Ass }\end{array}$ & $\mathrm{Cot}$ & Sep & $\begin{array}{l}\text { Do. } \\
\text { Poultry. }\end{array}$ \\
\hline Halifa & th Co. Agl. So & $\mathrm{Cot}$ & $\begin{array}{l}2 \mathrm{~d} \text { Wed. and Thurs. of } \\
\text { Sept. }\end{array}$ & General agr. \\
\hline Chill & Harerhill Ker & Inte & Feb. & Dogs. \\
\hline & Hinghar & Lo & $\begin{array}{l}\text { Last Tues. and Wed. } \\
\text { in Sept. }\end{array}$ & General agr. \\
\hline IIolyo'st & $\begin{array}{l}\text { Holyoke Poultry and Pet } \\
\text { Stock Assn. (Inc.). }\end{array}$ & Inter & $\begin{array}{l}\text { Wk. before Thanks- } \\
\text { giving. }\end{array}$ & $\begin{array}{l}\text { Poultry and } \\
\text { pet stock. }\end{array}$ \\
\hline n. & Kingston Poultry issn.... & & & litry. \\
\hline $\begin{array}{c}\text { L.enox } \\
\text { D }\end{array}$ & $\begin{array}{l}\text { Lenox Dog Show Assn. } \\
\text { Lenox Hort. Soc....... }\end{array}$ & $\begin{array}{l}\text { Natic } \\
\text { Inter: }\end{array}$ & $\begin{array}{l}\text { Sept } \\
3 \mathrm{~d} \text { wk. in Aug. and }\end{array}$ & $\begin{array}{l}\text { Dogs. } \\
\text { Horticulture. }\end{array}$ \\
\hline & & & $\begin{array}{l}\text { Oct. } \\
\text { 1st } w \mathrm{k} \text {. }\end{array}$ & $\mathrm{Po}$ \\
\hline Lov & North Agl. Soc. & $\mathrm{Co}$ & A bout middle of Sept. & General agr. \\
\hline & Lynn Kennel Club.............. & $\mathrm{Na}$ & Jan .................... & Dogs. \\
\hline & $\begin{array}{l}\text { Eastern Massachusetts Poul- } \\
\text { try and Pigeon Assn. }\end{array}$ & Lo & $\begin{array}{l}\text { Last } \pi k \text {. in Nor. or } \\
\text { 1st } \pi \mathrm{k} \text {. in Dec. }\end{array}$ & $\begin{array}{l}\text { Poultry and } \\
\text { pigeons. }\end{array}$ \\
\hline
\end{tabular}

REQUEST.-It is requested that everybody who is able to do so will send to this department corrections of errors in this bulletin and additions to the list of fairs and exhibitions. 
TABLE 4.-List of fairs and exhibitions devoted to agriculture, live stock, and other. related subjects, by States, 1912-Continued.

MASSACHUSETTS-Continued.

\begin{tabular}{|c|c|c|c|c|}
\hline $\begin{array}{l}\text { Place where } \\
\text { held. }\end{array}$ & $\begin{array}{l}\text { Name of fair, exhibition, or } \\
\text { association. }\end{array}$ & Area corered. & $\begin{array}{l}\text { Time when usually } \\
\text { held, or begins, or } \\
\text { range of dates with- } \\
\text { in which it is held. }\end{array}$ & $\begin{array}{l}\text { Kind of } \\
\text { exhibit. }\end{array}$ \\
\hline Marshfielu & Marshfielı Agl. and IIort. Sue. & Local & $=11$ Weil precerline $1 \mathrm{st}$ & Cieneral aur. \\
\hline Middlefield. & Highland Agl. Soc... & County. & 1st Wed.after ist Jion. & Do. \\
\hline Mrilford & Milford Poultry Assn. & & & Poultry. \\
\hline Nant & Nantucket & County.. & $\begin{array}{l}\text { Last Wed. and Thurs. } \\
\text { in Aug. }\end{array}$ & General agr. \\
\hline $\begin{array}{l}\text { New Bedford... } \\
\text { North Adams.. } \\
\text { Do......... }\end{array}$ & $\begin{array}{l}\text { New Berlford Hort. Soe....... } \\
\text { Hoosac Valley Agl. Soc....... } \\
\text { Northerm Berkshire Poultry }\end{array}$ & $\begin{array}{l}\text { Local ..... } \\
\text { Interstate. }\end{array}$ & $\begin{array}{l}\text { May, Jume, and Gept .. } \\
\text { Sept. } 1 . \ldots . . . . . . . . \\
\text { 3d wh. in Jan........ }\end{array}$ & $\begin{array}{l}\text { IIorticulture. } \\
\text { General agr. } \\
\text { Poultry. }\end{array}$ \\
\hline Northampton.. & Assn.(Ine.) Franklin, and & Intercount & 1st Wed. and Thurs. & General agr. \\
\hline North Reading. & $\begin{array}{l}\text { Hampden Agr. Soc. } \\
\text { New England Collie Club }\end{array}$ & Nation: & $\begin{array}{l}\text { in Oct. } \\
\text { Sept...... }\end{array}$ & Dogs. \\
\hline Oxford. & Oxford Agl. Soc....... & Cour & $\begin{array}{l}\text { Thurs. and Fri. before } \\
\text { 1st Mon, in Sept. }\end{array}$ & General agr. \\
\hline $\begin{array}{l}\text { Palmer........ } \\
\text { Reading and } \\
\quad \text { Wakefield. }\end{array}$ & $\begin{array}{l}\text { Eastern Hampden AgI. Soc... } \\
\text { Quannapowitt Agl. Assn.... }\end{array}$ & $\begin{array}{l}\text { Intercounty... } \\
\text { Local......... }\end{array}$ & $\begin{array}{l}\text { Oct. } 4 \text { to } 5 \ldots . . . . . . . . \\
\text { th wk. in Sept....... }\end{array}$ & $\begin{array}{l}\text { Do. } \\
\text { Do. }\end{array}$ \\
\hline $\begin{array}{l}\text { South W e y - } \\
\text { mouth. }\end{array}$ & $\begin{array}{l}\text { Weymouth } A g l \text { and Indus- } \\
\text { trial Assn. }\end{array}$ & Intercounty. & Between 1st and 20th & Do. \\
\hline Spencer..... & $\begin{array}{l}\text { Spencer Farmers' and Mechan- } \\
\text { ics' } A \text { ssn. }\end{array}$ & Local & Last wh. in Sept... & Do. \\
\hline Springfield. & $\begin{array}{l}\text { Springfield Poultry Club } \\
\text { (Ine.). }\end{array}$ & Natio & Dec.. & Poultry. \\
\hline Sturbridge & Worcester South Agl. Soc.. & Interstat & $\begin{array}{l}\text { 1st Thurs. and Fri.af- } \\
\text { ter } 2 d \text { Mon. in Sept. }\end{array}$ & General agr. \\
\hline Topsfield. & Essex Agl. Soc... & County & Between Sept. 15 and & Do. \\
\hline Uxbridg & Blackstone Valley $\Lambda$ gr. Soc... & .. & Tues. and Wed. 3d & Do. \\
\hline $\begin{array}{l}\text { Wenham........ } \\
\text { West Tisbury.. }\end{array}$ & $\begin{array}{l}\text { Essex Co. Poultry Assn ...... } \\
\text { Mtarthas Vineyard A } 1 . \text { Assn. }\end{array}$ & -...do. do. & $\begin{array}{l}\text { Dec } \\
\text { Last Tues. in dug...... }\end{array}$ & $\begin{array}{l}\text { Poultry. } \\
\text { General agr. }\end{array}$ \\
\hline Worcester. & Worcester Agl. Soc.. & Intersta & Opens Labor Day and & General agr. \\
\hline $\begin{array}{l}\text { Do......... } \\
\text { Do }\end{array}$ & $\begin{array}{l}\text { Worcester Poultry Assn. (Inc.) } \\
\text { Worcester Co. Hort. Soc...... }\end{array}$ & $\begin{array}{l}\text { Local... } \\
\text { County. }\end{array}$ & $\begin{array}{l}\text { Jan } \\
\text { Weekly, June to Sept. }\end{array}$ & $\begin{array}{l}\text { Poultry. } \\
\text { Horticulture. }\end{array}$ \\
\hline
\end{tabular}

\section{MICHIGAN.}

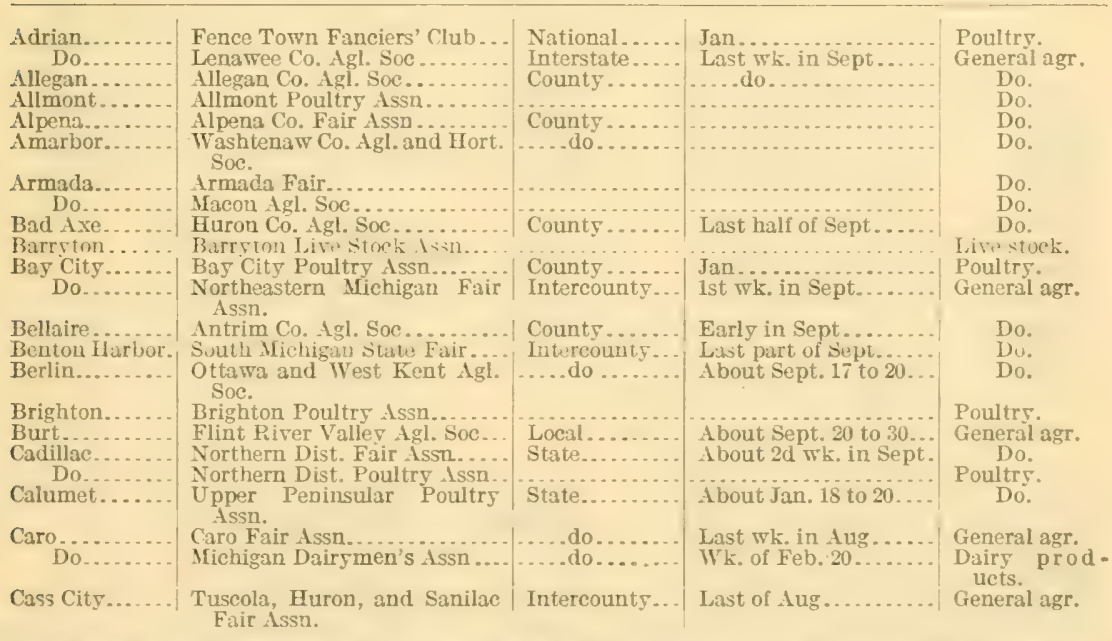

REQUEST.-It is requested that everybody who is able to do so will send to this department corrections of errors in this bulletin and additions to the list of fairs and exhibitions. 
TABLE 4.-List of fairs and exhibitions devoted to agriculture, live stock, and other related subjects, by States, 1912-Continued.

MICHIGAN-Continued.

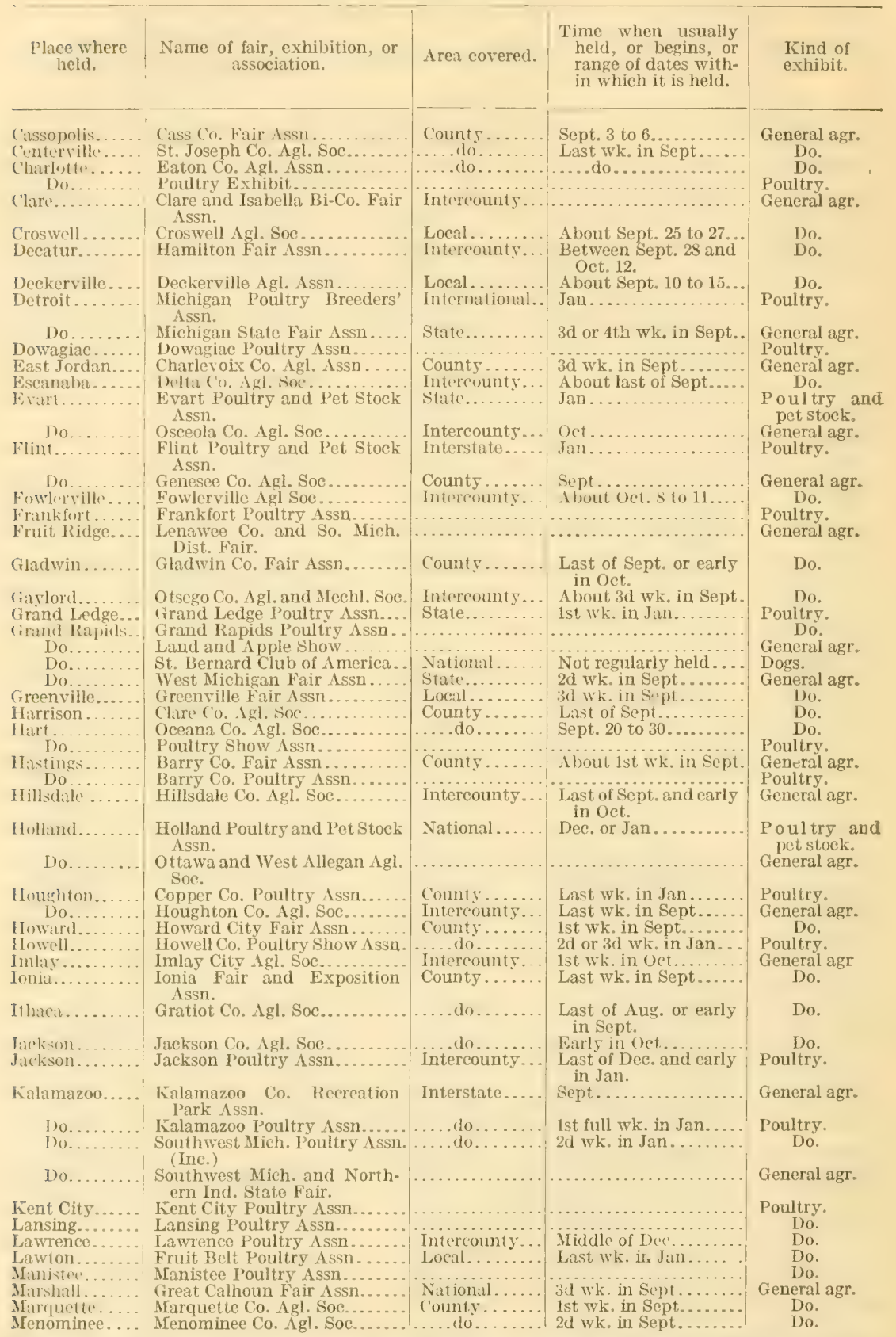

REQCEST. It is requested that everybody who is able to do so will send to this department corrections of errors in this bulletin and additions to the list of fairs and exhibitions. 
TABLE 4.-List of fairs and exhibitions devoted to agriculture, live stock, and other related subjects, by States, 1912 -Continued.

MICHIGAN-Continued.

\begin{tabular}{|c|c|c|c|c|}
\hline $\begin{array}{l}\text { Place where } \\
\text { held. }\end{array}$ & $\begin{array}{l}\text { Name of fair, exhibition, or } \\
\text { association. }\end{array}$ & Area covered. & $\begin{array}{l}\text { Time when usually } \\
\text { held, or begins, or } \\
\text { range of dates with- } \\
\text { in which it is held. }\end{array}$ & \\
\hline 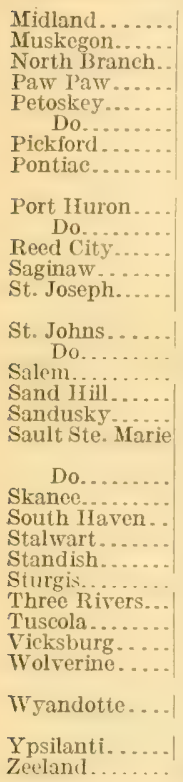 & 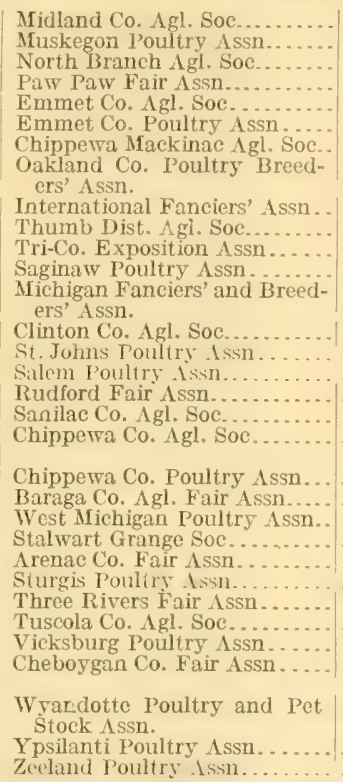 & 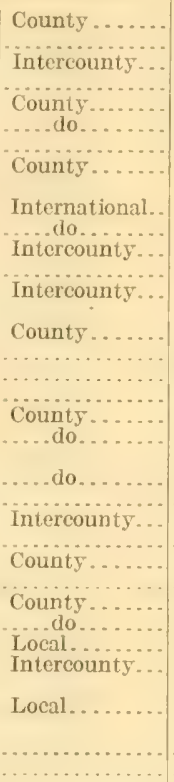 & 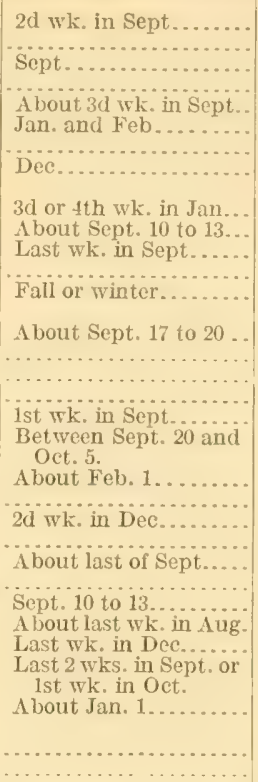 & $\begin{array}{l}\text { General agr. } \\
\text { Poultry. } \\
\text { General agr. } \\
\text { Do. } \\
\text { Do. } \\
\text { Poultry. } \\
\text { General agr. } \\
\text { Poultry. } \\
\text { Do. } \\
\text { General agr. } \\
\text { Do. } \\
\text { Poultry. } \\
\text { Do. } \\
\text { General agr. } \\
\text { Puultry. } \\
\text { Io. } \\
\text { Gereral agr. } \\
\text { Do. } \\
\text { Do. } \\
\text { Poultry. } \\
\text { General agr. } \\
\text { Poultry. } \\
\text { General agr. } \\
\text { Do. } \\
\text { Poultry. } \\
\text { General agr. } \\
\text { Do. } \\
\text { Poultry. } \\
\text { General agr. } \\
\text { Poultry and } \\
\text { pet stock. } \\
\text { Poultry. } \\
\text { Do. }\end{array}$ \\
\hline
\end{tabular}

\section{MINNESOTA.}

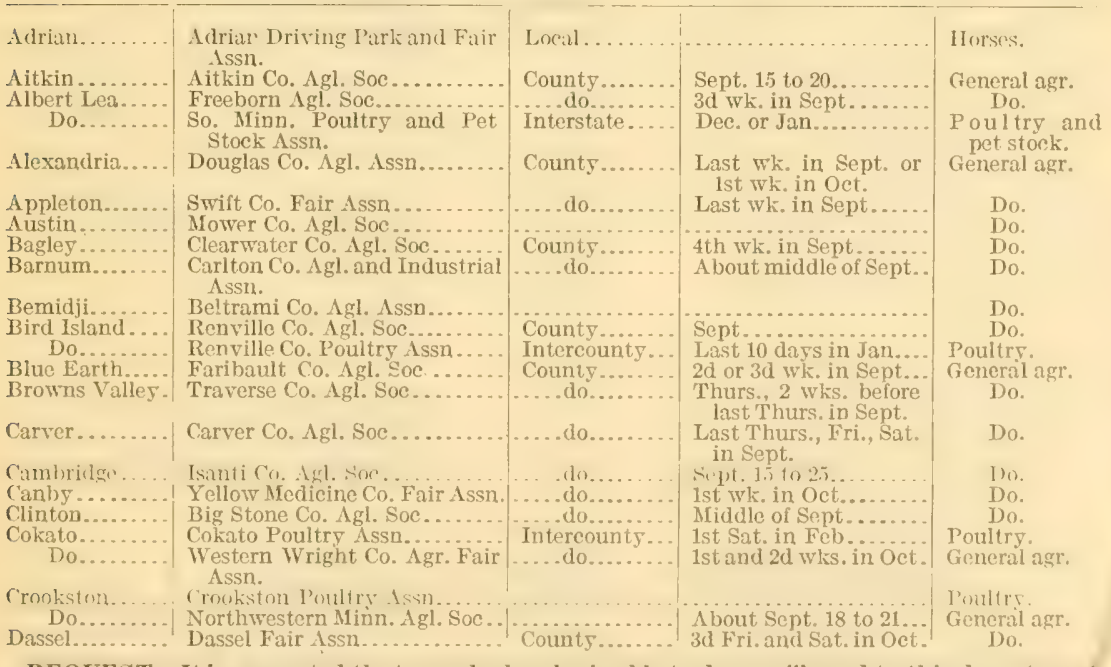

REQUEST.-It is requested that everybody who is able to do so will send to this department corrections of errors in this bulletin and alditions to the list of fairs and exhibitions. 
TABLE 4.-List of fairs and exhibitions devoted to agriculture, live stock, and other related subjects, by States, 1912-Continued.

MINNESOTA-Continued.

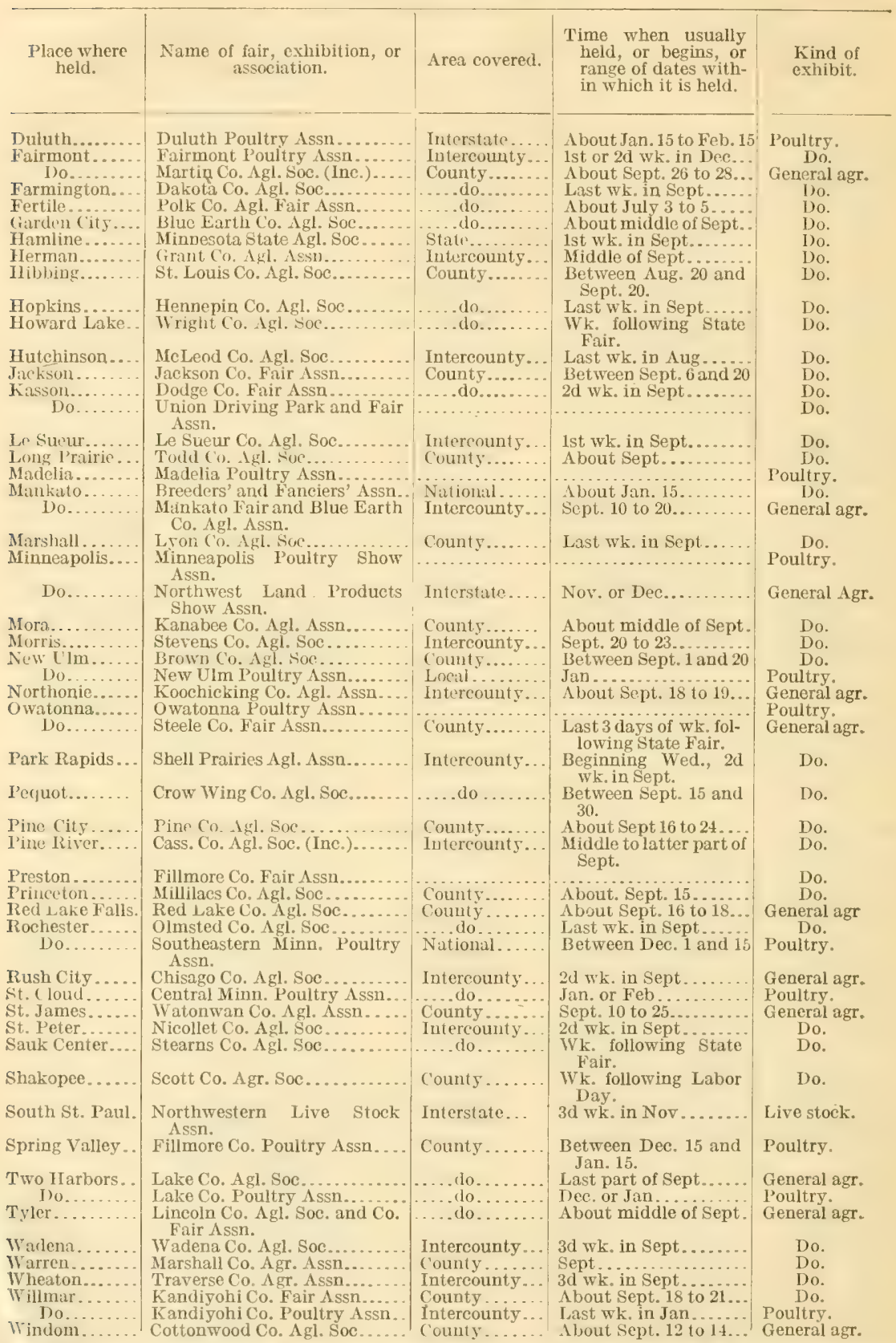

REQUEST.-It is requested that everybody who is able to do so will send to this department corrections of errors in this bulletin and additions to the list of fairs and exhibitions. 
TABLE 4.-List of fairs and exhibitions devoted to agriculture, live stock, and other related subjects, by States, 1912-Continued.

MINNESOTA-Continued.

\begin{tabular}{|c|c|c|c|c|}
\hline $\begin{array}{l}\text { Place where } \\
\text { held. }\end{array}$ & $\begin{array}{c}\text { Name of fair, exhibition, or } \\
\text { association. }\end{array}$ & Area covered. & $\begin{array}{l}\text { Time when usually } \\
\text { held, or begins, or } \\
\text { range of dates with- } \\
\text { in which it is held. }\end{array}$ & $\begin{array}{l}\text { Kind of } \\
\text { exhibit. }\end{array}$ \\
\hline $\begin{array}{l}\text { Winona........ } \\
\text { Do........ } \\
\text { Worthington... } \\
\text { Zumbrote...... }\end{array}$ & $\begin{array}{l}\text { Tri-County Fair Assn ....... } \\
\text { Winona Poultry Assn ........ } \\
\text { Nobles Co. Fair Assn........ } \\
\text { Goodhue Co. Agl. Soc........ }\end{array}$ & $\begin{array}{l}\text { Local ...... } \\
\text { County..... } \\
\text {.... do......... }\end{array}$ & $\begin{array}{l}\text { Between Sept. } 1 \text { and } \\
20 \text {. } \\
\text { Between Sept. } 15 \text { and } \\
24 \text {. }\end{array}$ & $\begin{array}{l}\text { General agr. } \\
\text { Do. } \\
\text { Do. } \\
\text { Do. }\end{array}$ \\
\hline
\end{tabular}

\begin{tabular}{|c|c|c|c|c|}
\hline & Lenregen four sen & & & \\
\hline Baldwyn. & Northeast Miss, Fair Assn.... & State. & About sept if to & General agr. \\
\hline Booneville.... & Prentiss Co. Fair Assn....... & County........... & 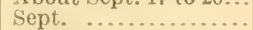 & Do. \\
\hline Brookhaven.... & Lincoln Co. Fair Assn........ & Intercounty... & Latter part of Oct.. & Do. \\
\hline Canton ........ & Madison Co. Fair Assn... & County....... & $2 \mathrm{~d}$ or $3 \mathrm{~d} w \mathrm{k}$, in Oct... & Do. \\
\hline olumbus...... & Miss. and West Ala. Fair Assn. & Interstate.... & Between Oct. 1 and 15. & Do. \\
\hline orinth .... & Corinth Horse Show Assn.... . & & & Horses. \\
\hline Do... & Alcorn Co. Fair Assn..... & County & Oet.. & General agr. \\
\hline $\begin{array}{l}\text { Ellisville....... } \\
\text { Estes Mili }\end{array}$ & Fair Assn ........ & & & $\mathrm{D}$ \\
\hline $\begin{array}{l}\text { Estes } \\
\text { Glost }\end{array}$ & Tri-County Fair Assn .... & Intercounty... & $\begin{array}{l}1 \text { iues. } \\
20 \mathrm{t} \text {. }\end{array}$ & $\begin{array}{l}\text { Do. } \\
\text { Do. }\end{array}$ \\
\hline Grenada. & $\begin{array}{l}\text { Central Fair and Live stock } \\
\text { Assn. }\end{array}$ & .... do ........ & Oct................... & Do. \\
\hline Gulfport & Gulfport Poultry Assn... & & & Poultry. \\
\hline Do & Miss. and Gulf Coast Expo. Co. & Intercounty. & $\begin{array}{l}\text { Between Oct. } 15 \text { and } \\
\text { Nov. } 15 \text {. }\end{array}$ & General agr. \\
\hline Do & National Nut Growers' Assn. . & National & Oct. or Nov & Nuts. \\
\hline Holly Sprix & North Mississippi Fair... & & & General agr. \\
\hline Houston. . & Chickasaw Co. Fair Assn.. & County. & Oct. 9 to 12 . & Do. \\
\hline Iuka..... & Iuka Poultry Assn ........... & & & Poultry. \\
\hline son & ppi itate Fair Issn... & $i 1$ & Oet. 20 to No & General agr. \\
\hline Do.... & $\begin{array}{l}\text { Holmes Co. Fair Assn.......... } \\
\text { Holmes Co. Poultry Assn..... }\end{array}$ & $\begin{array}{l}\text { County... } \\
\text {.....do... }\end{array}$ & Oct........... & $\begin{array}{l}\text { Do. } \\
\text { Poultry. }\end{array}$ \\
\hline Louisville. & WV inston Co. Fair $\Lambda$ ssn........ & & About middle of Sept. & General agr. \\
\hline $\begin{array}{l}\text { Aiacon ... } \\
\text { Meridian }\end{array}$ & Noxubee Co. Fair 1 ssn ........ & & & Do. \\
\hline ridian. & $\begin{array}{l}\text { East Miss. Poultry Assn } \ldots . . . \\
\text { Mississippi-Alabama F a i }\end{array}$ & Intercounty ... & $2 \mathrm{~d}$ full wk. in Dec. & Poultry. \\
\hline & 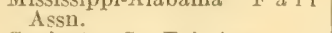 & & e & teral agt \\
\hline Mit. & Covington Co. Fair Assn..... & Co & $\mathrm{Be}$ & D \\
\hline $\mathrm{Na}$ & Natchez Fair Assn...... & In & $\begin{array}{l}\text { Between Oct. } 1 \text { and } \\
\text { Nov. } 10 .\end{array}$ & Do. \\
\hline Philadelphia. & Nesho & Inte & & Do. \\
\hline Port G & Claiborne Co. Agl. Fair Assn... & County.. & 1st ten days of Nov.. & Do. \\
\hline Senato & o. Fair Assn............ & Intercounty... & in Oct.. & Do. \\
\hline Starkville & Oktibbeha Co. Fair Assn.... & County .... & Last of Sept. or early & Do. \\
\hline Tupelo & Mississippi Poultry & Interstat & $\mathrm{D}$ & Poultry. \\
\hline D & Tri-County Fair Assn. . & Intercounty.. & About & $\mathrm{Ge}$ \\
\hline & ( & $\cdots$ & & \\
\hline
\end{tabular}

\section{MISSOURI}

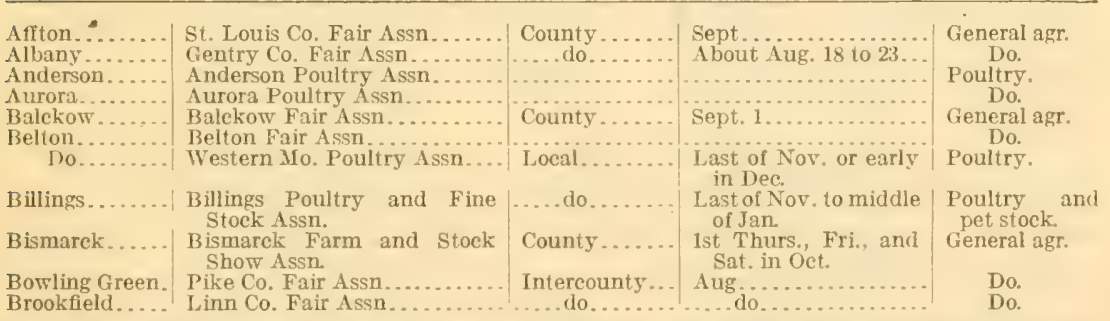

IREUEST.-It is requested that everybody who is able to do so will send to this department corrections of errors in this bulletin and additions to the list of fairs and exhibitions. 
TABLE 4.- List of fairs and exhibitions deroted to agriculture, live slock, and other related subjects, by Stales, 1912-C'ontinued.

MISSOURI-Continued.

\begin{tabular}{|c|c|c|c|c|}
\hline $\begin{array}{l}\text { Place where } \\
\text { hekl. }\end{array}$ & $\begin{array}{c}\text { Name of fair, exhibition, or } \\
\text { association. }\end{array}$ & Area covered. & $\begin{array}{l}\text { Time when usually } \\
\text { hold, or begins, or } \\
\text { range of dates with- } \\
\text { in which it is held. }\end{array}$ & $\begin{array}{l}\text { Kind of } \\
\text { exhibit. }\end{array}$ \\
\hline$\ldots \ldots$ & $\cdots-$ & & & $-\ldots$ \\
\hline Bunceton. & Bunceton Fair Assn......... & Commey & Last full wk, in $\Lambda u g . .$. & General agr. \\
\hline $\begin{array}{l}\text { Butler.... } \\
\text { Do.... }\end{array}$ & $\begin{array}{l}\text { Bates Co. Fair Assn ......... } \\
\text { Bates Co. Poultry Assn..... }\end{array}$ & stile. & $\begin{array}{l}\text { About middle of Sept. } \\
\text { Fall }\end{array}$ & Do. \\
\hline Cabool... & $\begin{array}{l}\text { Texas Co. Agl. and Breeders } \\
\text { Assn. }\end{array}$ & Intersiale. & $\begin{array}{l}\text { Latter part of } \mathrm{dug} \text {, or } \\
\text { early in sept. }\end{array}$ & Feneral agr. \\
\hline California... & $\begin{array}{l}\text { Monitean Co. Agl. and Mechl. } \\
\text { Soe. }\end{array}$ & County. & $\Lambda$ bout 1st wk. in Sept. & Do. \\
\hline Callao.......... & Callao Fair $\Lambda$ ssn. . . . . . . . . . . & $\ldots$ ilt & Sept & Do. \\
\hline $\begin{array}{l}\text { (ampluell ....... } \\
\text { ('ape (rirardeail }\end{array}$ & $\begin{array}{l}\text { Campbell Fair Assn. .......... } \\
\text { Cape Girardeau Co. Fair and } \\
\text { Park } \Lambda \text { ssn. }\end{array}$ & $\begin{array}{l}\text { l.mall } \\
\text { futm! }\end{array}$ & Last of Seper & $\begin{array}{l}\text { Do. } \\
\text { i)o. }\end{array}$ \\
\hline ('arthign.. & Carthage F'oultry Assn...... . & & & Poultry. \\
\hline 1) o. & $\begin{array}{l}\text { Jasper Co. Fair Ass } \\
\text { Pemiscot Co Fair }\end{array}$ & Init & 111世. & General agr. \\
\hline ('assville...... & Barry Co. Fair Assn... & County. & Sept or early in Oct.. & $\begin{array}{l}\text { Do. } \\
\text { 1)o. }\end{array}$ \\
\hline Centralia...... & Centralia Fair Assn.... & Intercounty. & $3 \mathrm{~d} w h$, in $\mathrm{Aug} . . .$. & 110. \\
\hline Chillicothe..... & $\begin{array}{l}\text { Centrail Poultry } A \text { ssn } \\
\text { Northwest Mo. Fanciers } \Lambda \text {. }\end{array}$ & Internat ior & Now..... & $\begin{array}{l}\text { Pontiry. } \\
\text { loo. }\end{array}$ \\
\hline Chilowee...... & Chilowee Colt Show.......... & & & IIUrits. \\
\hline Clark .......... & Clark Fair Assn $\ldots \ldots \ldots$ & & A bout 1st wk. in Sept. & General agr. \\
\hline (1) & Cithinet farmed ( Thi)...... & l.ocial. & $\begin{array}{l}\text { Between Oct. } 20 \text { and } \\
\text { Nov. 1. }\end{array}$ & Do. \\
\hline rlinton........ & Clinton Poultry Assn . ...... & & About July & Poultry. \\
\hline [1, ${ }_{0} \ldots \ldots \ldots$ & Boone Co. J'outtry Assn...... & $\begin{array}{l}\text { mterstate..... } \\
\text { County...... }\end{array}$ & $\begin{array}{l}\text { About July } 23 \text { to } 20 \ldots . \\
2 d \text { wk in Jan........ }\end{array}$ & $\begin{array}{l}\text { General agr. } \\
\text { Poultry. }\end{array}$ \\
\hline $10_{0} \ldots \ldots$ & Missouri State Board of Hort.. & State......... & $\begin{array}{l}1 \text { in Oct. or Nov, and } \\
1 \text { the ist wk. in Jan. }\end{array}$ & Horticulture. \\
\hline Concordial. . . . & Concordia Poultry Assn & Local. & 3 i wh. in Nov ....... & Poultry. \\
\hline (rystill c'it & $\begin{array}{l}\text { Jelierson Co. Agl. and Fair } \\
\text { Assn. }\end{array}$ & Inirrevillt & $2 \mathrm{~d}$ or $3 \mathrm{~d}$ wh. in Sept... & General agr. \\
\hline $\mathrm{C} 12 b_{a} \ldots \ldots \ldots$ & Crawford Co. Fair Assn ....... & $\because \ldots 10$ & th Mon. in Sept..... & 1)o. \\
\hline $13+2(1)$ & $\begin{array}{l}\text { De soto live stock Agl. and } \\
\text { Hort. Assn. }\end{array}$ & Colim! & $\begin{array}{l}\text { last of Sept. and early } \\
\text { in Oet. }\end{array}$ & Do. \\
\hline 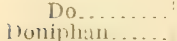 & $\begin{array}{l}\text { Jeflerson Co. Poultry Assn .... } \\
\text { Ripley Co. Corn Growers'Assn. }\end{array}$ & Intercounty... & Dec. or Jan ....... & Poultry. \\
\hline I) $1, \ldots$ & Ripley Co. Poultry Assn..... & .... dio.. & Not............. & Poultry. \\
\hline Easton... & $\begin{array}{l}\text { Buchanan Co. Agl. and Mechl. } \\
\text { Soc. }\end{array}$ & $x_{-1}$ & sep $1 . . . \ldots \ldots \ldots$. & General agr. \\
\hline Edina......... & Edina Poultry Assn... & & & Poultry. \\
\hline $\begin{array}{l}\text { E. } x \text { ce } 1 \text { s } 10 \text { r } \\
\text { Springs. }\end{array}$ & (tily ( & & & General agr. \\
\hline Farmington.... & $\begin{array}{l}\text { Excelsior springs Poultry Assn } \\
\text { Southeast MI. Fair Assn . . . . . }\end{array}$ & Intercommly.. & M id & $\begin{array}{l}\text { Poultry. } \\
\text { General agr. }\end{array}$ \\
\hline $\begin{array}{l}\text { Filyotin } \\
\text { liestus. }\end{array}$ & Howard Co. Fair Assn ......... & Lutareoum & & Do. \\
\hline l'estus... & $\begin{array}{l}\text { Jellerson Co. } \Lambda \text { gl. and Fair } \\
\text { Assn. }\end{array}$ & Intereons & 211 or 3 d wk. in sejpt... & Do. \\
\hline Forest Green. & Forest Green Fair Assn. ..... & Jocil. & sejt. & Do. \\
\hline fallatin. & $\begin{array}{l}\text { Fulton Poultry Assn ........... } \\
\text { Daviess Co. Poultry Assn .... }\end{array}$ & $\begin{array}{l}\text { State... } \\
\text { county }\end{array}$ & Fall or winter. & Poultry. \\
\hline Gentry ....... & Gentry Colt Show Assn...... & $\ldots$... $10 . .$. & About Sept 1 & Horses. \\
\hline Gordonville. & $\begin{array}{l}\text { Cape Girardeau Co. Poultry } \\
\text { Issn. }\end{array}$ & Intercounty & Last wk. in Dec.... & Poultry. \\
\hline $\begin{array}{l}\text { Harrisonville... } \\
\text { Harmann..... }\end{array}$ & 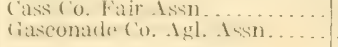 & $\begin{array}{l}\text { ('ouming. } \\
\text { a.tolo. }\end{array}$ & $\begin{array}{l}\text { Sept. or Oct.......... } \\
\text { Last of Aug. or eariy }\end{array}$ & $\begin{array}{c}\text { General agr. } \\
\text { Do. }\end{array}$ \\
\hline Hermitage & Hickory Co & & & Do. \\
\hline Higginsville & Lafayette Co. Fair Assn....... & Intercounty & Alug....... & Do. \\
\hline Holden. & $\begin{array}{l}\text { Johnson Co. Agl. and MIechl. } \\
\text { Assn. }\end{array}$ & $\begin{array}{l}\text { County } \\
\text {. . nllo. }\end{array}$ & $\begin{array}{l}\text { Tec. } 25 \text { to } 24 . \\
\text { H11:......... }\end{array}$ & $\begin{array}{l}\text { Poultry: } \\
\text { (ienerat agr. }\end{array}$ \\
\hline Independence.. & Independence Fair $A$ ssn. ..... & Intereounty. & Last wk. in $A u g . . . .$. & Do. \\
\hline & $\begin{array}{l}\text { Randolph Co. } 1 \text { gl. and Mechl. } \\
\text { Soc. }\end{array}$ & & $\begin{array}{l}\text { Last of Aug. or early } \\
\text { in Sept. }\end{array}$ & Do. \\
\hline Jefferson City. & Jefferson City Pouitry Assn... & & & Poultry. \\
\hline Joplin. & $\begin{array}{l}\text { New Cole Co. Fair Assn . . . . . . } \\
\text { Ozark Interstate Expo ........ }\end{array}$ & & Se & $\begin{array}{c}\text { General agx. } \\
\text { Do. }\end{array}$ \\
\hline Kanob: & Clark Co.Agl. and Mechl. Assn. & & $\begin{array}{l}\text { Last wk, in Aug. or } \\
\text { lst wk. in Sept. }\end{array}$ & \\
\hline 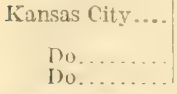 & $\begin{array}{l}\text { American Royal Live Stock } \\
\text { Show. } \\
\text { Kansas City Fanciers' Assn... } \\
\text { Kansas City Kennel Club.... }\end{array}$ & International. & $2 \mathrm{l}$ wh. in Oet... & $\begin{array}{l}\text { Jive stock. } \\
\text { I'oultry. } \\
\text { Dogs. }\end{array}$ \\
\hline
\end{tabular}

IREUEST.-It is requested that fverybody who is able to do so will send to this department corrections of errors in this bulletin and additions to the list of fairs and exhibitions. 
TABLE 4.-List of fairs and exhibitions devoted to agriculture, live stock, and other relaterl subjects, by States, 1912-Continued.

MISSOURI-Continued.

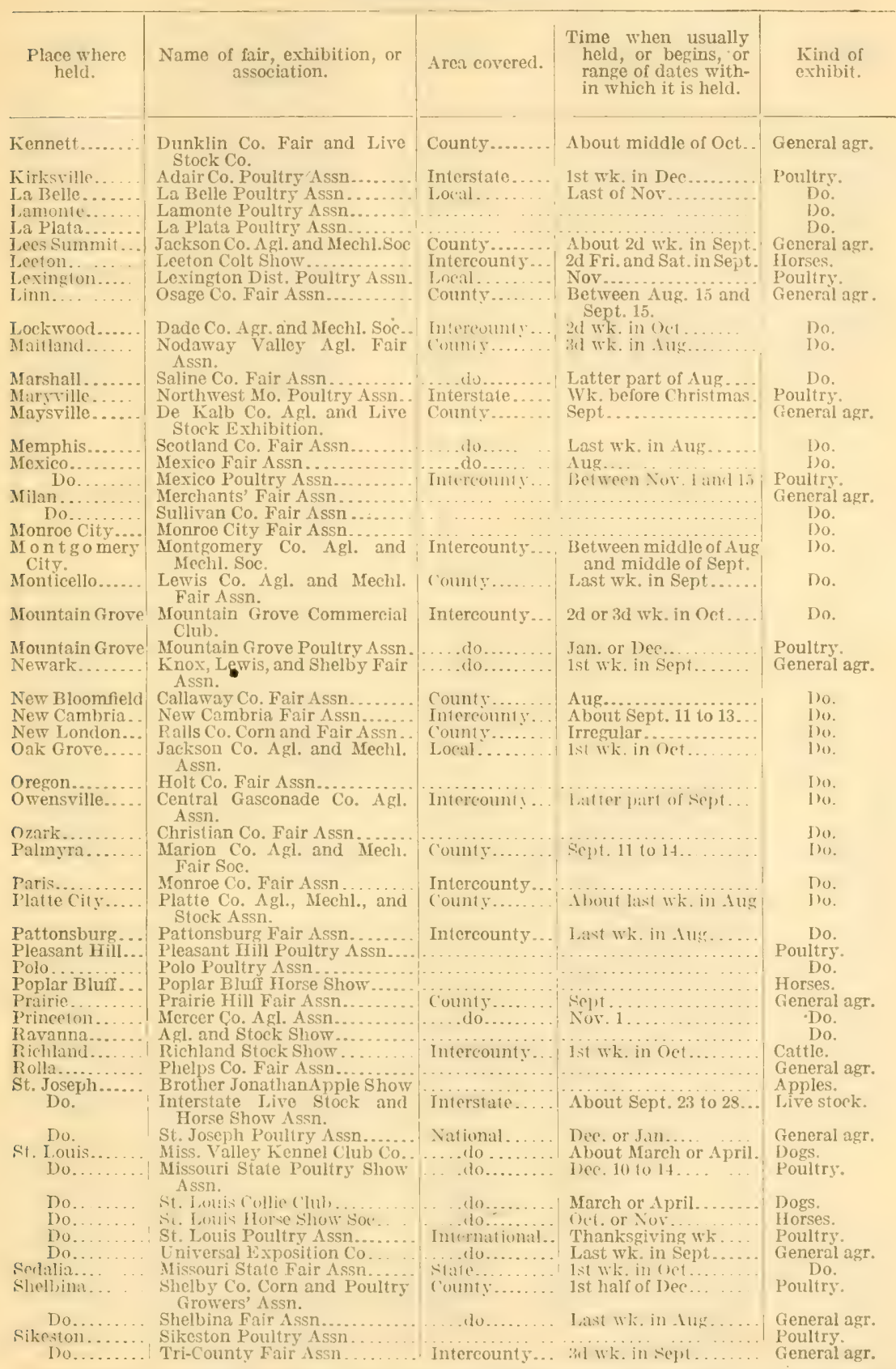

REQUEST.-It is requested that everybody who is able to do so will send to this department corrections of errors in this bulletin and additions to the list of fairs and exhibitions. 
'TABLE 4.-List of fairs and exhibitions devoted to agriculture, live stock, and other related subjects, by States, 1912 - Continued.

MISSOURI-Continued.

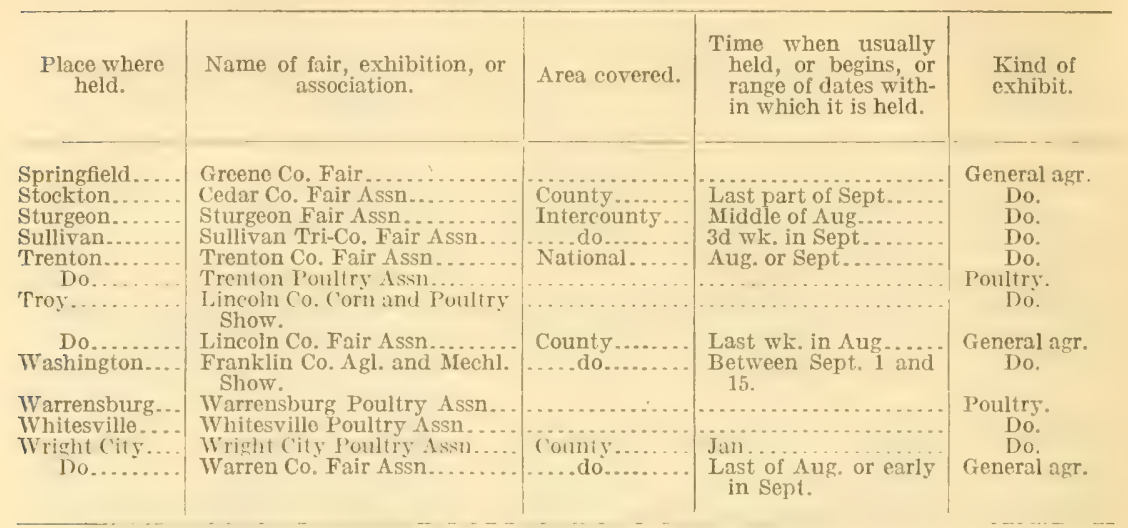

MONTANA.

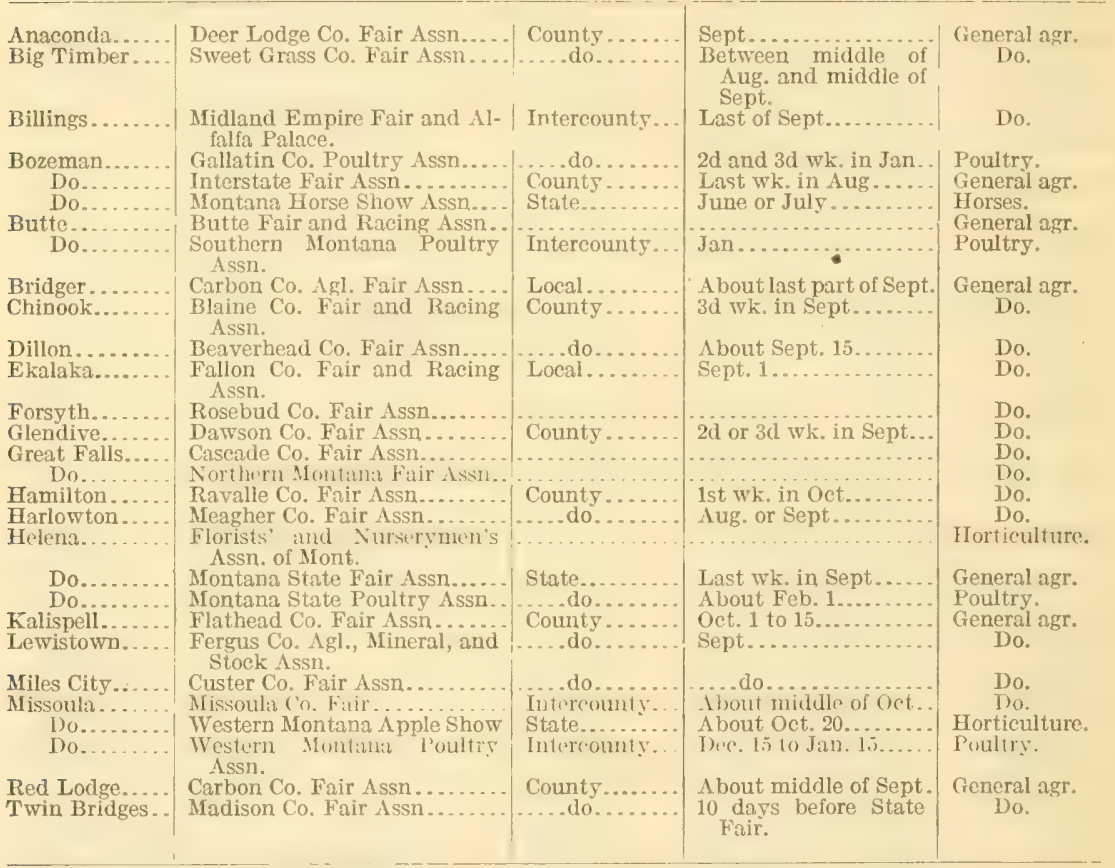

\section{NEBRASKA}

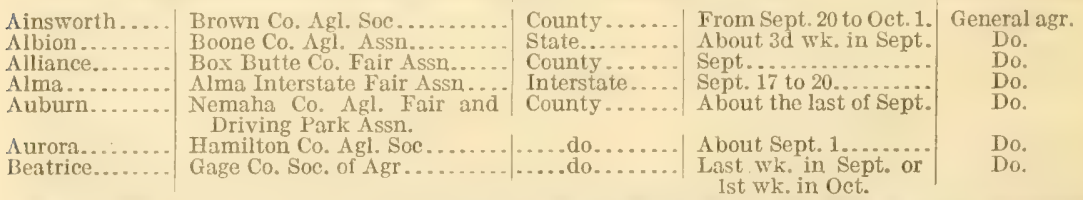

REQUEST.-It is requested that everybody who is able to do so will send to this department corrections of errors in this bulletin and additions to the list of fairs and exhibitions. 
TABLE 4.-List of fairs and exhibitions devoted to agriculture, live stoch, and other related subjects, by States, 1912 -Continued.

NEBRASKA-Continued.

\begin{tabular}{|c|c|c|c|c|}
\hline $\begin{array}{l}\text { Place where } \\
\text { held. }\end{array}$ & $\begin{array}{c}\text { Name of fair, exhibition, or } \\
\text { association. }\end{array}$ & Area covered. & $\begin{array}{l}\text { Time when usually } \\
\text { held, or begins, or } \\
\text { range of dates with- } \\
\text { in which it is held. }\end{array}$ & $\begin{array}{l}\text { Kind of } \\
\text { exhibit. }\end{array}$ \\
\hline 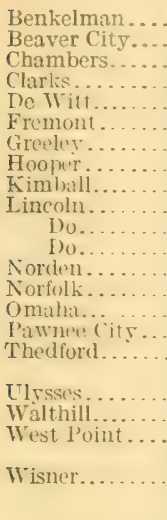 & 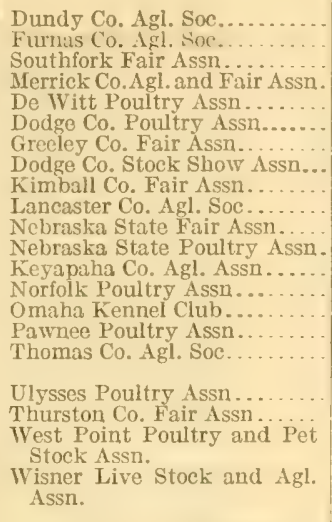 & 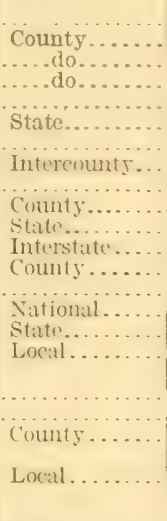 & 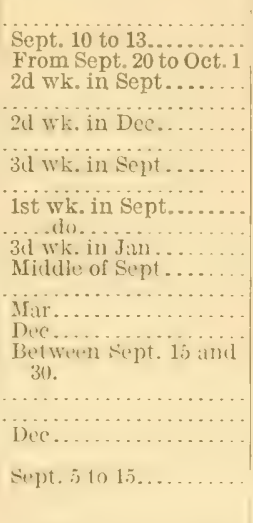 & $\begin{array}{l}\text { General agr. } \\
\text { Do. } \\
\text { Do. } \\
\text { Do. } \\
\text { Poultry. } \\
\text { Do. } \\
\text { General agr. } \\
\text { Live stock. } \\
\text { General agr. } \\
\text { Do. } \\
\text { Do. } \\
\text { Poultry. } \\
\text { General agr. } \\
\text { Poultry. } \\
\text { I)egs. } \\
\text { Poultry. } \\
\text { General agr. } \\
\text { Poultry. } \\
\text { General agr. } \\
\text { Poultry and } \\
\text { pet stock. } \\
\text { General agr. }\end{array}$ \\
\hline
\end{tabular}

NEW HAMPSHIRE,

\begin{tabular}{|c|c|c|c|c|}
\hline 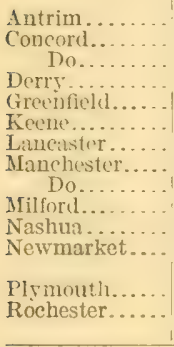 & 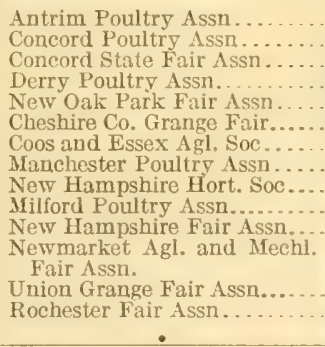 & $\begin{array}{l}\text { International. } \\
\text { Local......... } \\
\text { Intercounty... } \\
\text { International.. }\end{array}$ & 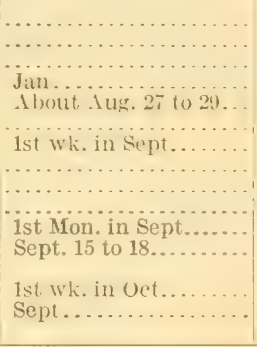 & $\begin{array}{c}\text { Poultry. } \\
\text { Do. } \\
\text { General agr. } \\
\text { Poultry. } \\
\text { General agr. } \\
\text { Do. } \\
\text { Do. } \\
\text { Poultry. } \\
\text { Horticulture. } \\
\text { Poultry. } \\
\text { General agr. } \\
\text { Do. } \\
\text { Do. } \\
\text { Do. }\end{array}$ \\
\hline
\end{tabular}

NEW JERSEY.

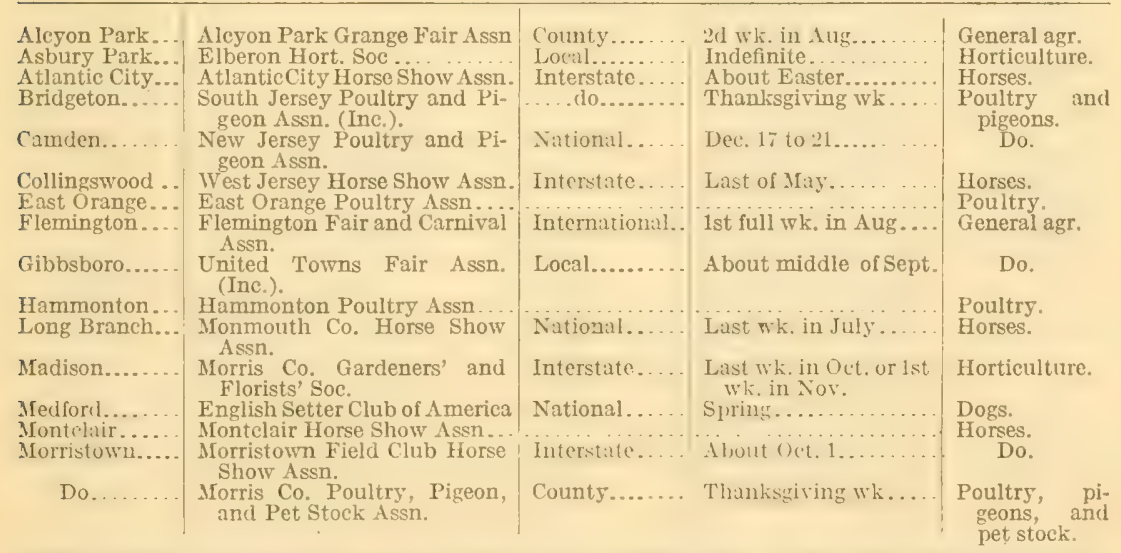

REQUEST. - It is requested that everybody who is able to do so will send to this department corrections of errors in this bulletin and additions to the list of fairs and exhibitions. 
TABLE 4.-List of fairs and exhibitions devoted to aqriculture, live stock, and other related subjects, by States, 1912-Continued.

NEW JERSEY-Continued.

\begin{tabular}{|c|c|c|c|c|}
\hline $\begin{array}{l}\text { Place where } \\
\text { held. }\end{array}$ & $\begin{array}{c}\text { Name of fair, exhibition, or } \\
\text { association. }\end{array}$ & Area covered. & $\begin{array}{l}\text { Time when usually } \\
\text { held, or begins, or } \\
\text { range of dates with- } \\
\text { in which it is held. }\end{array}$ & $\begin{array}{l}\text { Kind of } \\
\text { exhibit. }\end{array}$ \\
\hline Mount Holly.. & Burlington $\mathrm{Co}, \Lambda \mathrm{gl}, \mathrm{Assn} . . . .$. & Intercounty... & About Oct. 8 to $11 .$. & General agr. \\
\hline Do........ & $\begin{array}{l}\text { Mount Holly Horse Show } \\
\text { Assn. }\end{array}$ & & .................... & Horses. \\
\hline Newark. & New Jersey Horse Show Assn. & & & Do. \\
\hline Do. & $\begin{array}{l}\text { West Highland White Terrier } \\
\text { Club. }\end{array}$ & National. & Spring or & Dogs. \\
\hline Passaic. & $\begin{array}{l}\text { Passaic Poultry, Pigeon, and } \\
\text { Pet Stock Assn. }\end{array}$ & Intercounty. . & About Jan. 10 to $15 . .$. & $\begin{array}{l}\text { Poultry, pi- } \\
\text { geons, and } \\
\text { pet stock. }\end{array}$ \\
\hline Paterso & Paterson Poultry Show....... & & & Poultry. \\
\hline Pitmai & Algon Park Grange Fair Assn. & County. & 2d wk. in Aug.. & General agr. \\
\hline Plainfiel & Plainfield Kennel Club (Inc.). & National. & June or Oet... & Dogs. \\
\hline Do. & $\begin{array}{l}\text { Plainfield Riding and Driving } \\
\text { Club. }\end{array}$ & Interstate & 1st wk. in June. & Horses. \\
\hline Red Bank. & Monmouth Co. Agl. Fair Assn. & County... & $\begin{array}{l}\text { Labor Day and } 3 \text { days } \\
\text { preceding. }\end{array}$ & General agr. \\
\hline Do. & Monmouth Co. Hort. Soc.... & National. & Last of Oct. or early in & \\
\hline Do & Monmouth Poultry Club..... & do. & Nov, or Dec.......... & Poultry. \\
\hline Rutherford. & Rutherford Poultry Assn..... & & $\ldots \ldots \ldots \ldots \ldots$ & Do. \\
\hline Sea Girt.. & $\begin{array}{l}\text { Sea Girt and Spring Lake } \\
\text { Horse Show Assn. }\end{array}$ & National & First wh, in Aug. & Horses. \\
\hline Trentor & Interstate Fair Assn......... & Interstat & Last Mon, in Sept & General agr. \\
\hline Do. & Trenton Kennel Club Assn.... & ..... do.. & Sept..... & Dogs. \\
\hline Fin & Trenton Poultry and Pigeon & - & De & $\begin{array}{l}\text { Poultry and } \\
\text { pigeons. }\end{array}$ \\
\hline $\begin{array}{l}\text { Yineland.. } \\
\text { IVashingto }\end{array}$ & $\begin{array}{l}\text { Vineland Poultry Assn........ } \\
\text { Washington Poultry Pigeon. }\end{array}$ & Inter: & $2 \mathrm{~d}$ wk. in Jan. & $\begin{array}{l}\text { Poultry. } \\
\text { Poultry, pi- }\end{array}$ \\
\hline W ashing & $\begin{array}{l}\text { Washington Poultry, Pigeon, } \\
\text { and Pet Stoek Assn. (Inc.). }\end{array}$ & 11DUED & & $\begin{array}{l}\text { geons, and } \\
\text { pet stock. }\end{array}$ \\
\hline West En & Monmouth Co. Kennel Club.. & National. & July.... & Dogs. \\
\hline
\end{tabular}

NEVADA

\begin{tabular}{|c|c|c|c|}
\hline $\begin{array}{l}\text { Reno... } \\
\text { Do.. }\end{array}$ & $\begin{array}{l}\text { Nevada Agl. Assn............. } \\
\text { Nevada State Poultry Assn... }\end{array}$ & $\begin{array}{l}\text { State........... } \\
\text { International.. }\end{array}$ & $\begin{array}{l}\text { 1st wk. in Sept........ } \\
\text { Jan................ }\end{array}$ \\
\hline
\end{tabular}

\section{NEWV MEXICO}

\begin{tabular}{|c|c|c|c|c|}
\hline 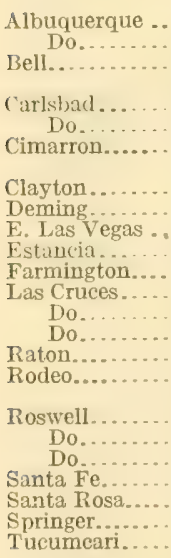 & 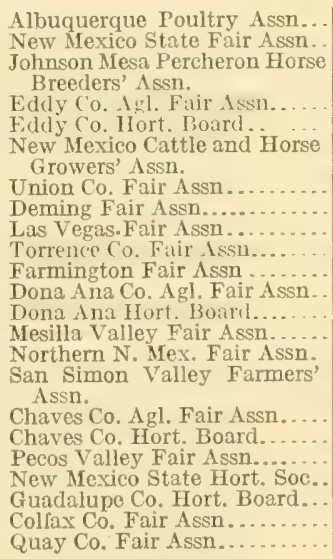 & $\begin{array}{c}\text { Intercount } \\
\ldots . . . \\
\text { County............ } \\
\ldots . . \text { do.... }\end{array}$ & 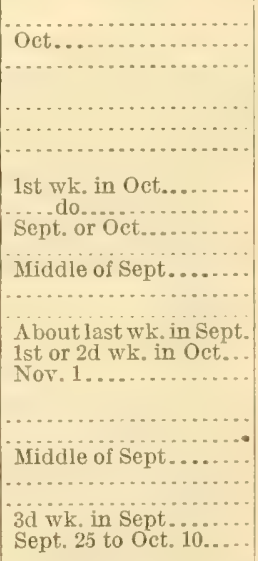 & $\begin{array}{l}\text { Poultry. } \\
\text { General agr. } \\
\text { Horses. } \\
\text { (ieneral agr. } \\
\text { Horticulture. } \\
\text { Live stock. } \\
\text { General agr. } \\
\text { Do. } \\
\text { Do. } \\
\text { Do. } \\
\text { Do. } \\
\text { Do. } \\
\text { IIorticulture. } \\
\text { General agr. } \\
\text { Do. } \\
\text { Do. } \\
\text { Do. } \\
\text { Horticulture. } \\
\text { General agr. } \\
\text { Horticulture. } \\
\text { Do. } \\
\text { General agr. } \\
\text { Do. }\end{array}$ \\
\hline
\end{tabular}

IREQUEST.-It is requested that everybody who is able to do so will send to this department corrections of errors in this bulletin and additions to the list of fairs and exhibitions. 
TABLE 4-List of fairs and exhibitions devoted to agricullure, live stock, and other related subjects, by States, 1912-Continued.

NEIV YORI.

\begin{tabular}{|c|c|c|c|c|}
\hline $\begin{array}{l}\text { Place where } \\
\text { held. }\end{array}$ & $\begin{array}{c}\text { Name of fair, exhibition, or } \\
\text { association. }\end{array}$ & Area covered. & $\begin{array}{l}\text { Time when usually } \\
\text { held, or begins, or } \\
\text { range of dates with- } \\
\text { in which it is held. }\end{array}$ & $\begin{array}{l}\text { Kind of } \\
\text { exhibit. }\end{array}$ \\
\hline Afton . . . . . . & Afton Driving Park and $\mathrm{Agl}$. & Local... & About middle of Sept.. & General agr. \\
\hline Allamy.... & Florists' Show .................. & & & Floriculture. \\
\hline 190. & Fort Orange Poultry and Pet & Int & Jar & $\begin{array}{l}\text { Poultry and } \\
\text { petstock. }\end{array}$ \\
\hline $\begin{array}{l}\text { 1)o.. } \\
\text { Allionll. }\end{array}$ & $\begin{array}{l}\text { Glemont Fair Assn } \ldots \ldots \\
\text { Orleans Co. } \mathrm{Agl} \text {. Soc } \ldots \ldots\end{array}$ & $\begin{array}{l}\text { Intercounty. } \\
\text { Cominty...... }\end{array}$ & $2 \mathrm{~d}$ wk. in Sept. & $\begin{array}{l}\text { General agr. } \\
\text { Do. }\end{array}$ \\
\hline Iltamon & Albany Co. Agl. Soc and Expo. & State......... & $3 \mathrm{l}$ wk. in lut. & Do. \\
\hline $\begin{array}{l}\text { Angelica... } \\
\text { Aulourn... }\end{array}$ & $\begin{array}{l}\text { Allegany Co. Agl. Soc........... } \\
\text { Cayug Co. Poultry Assn..... }\end{array}$ & Coutnty........ & About Sept. 10 to $12 .$. & Do. \\
\hline Ballston Spa... & Saratoga Co. Agl. Soc........... & ... & Last wk. in Aug........ & $\begin{array}{l}\text { Poultry. } \\
\text { General agr. }\end{array}$ \\
\hline Batavia........ & Genesee Co. Agr. Soc..... & . dlo... & 3d wk. in Sept........ & Do. \\
\hline $\begin{array}{l}\text { Bath............ } \\
\text { Bay Shore.... }\end{array}$ & $\begin{array}{l}\text { Steuben Co. Agl. Soc............ } \\
\text { Bay Shore Horse Showy }\end{array}$ & Interstat & Aug. and sept.. & Do. \\
\hline Binghamton... & Binghamton Industrial Expo. & Interstale. & Last wk. in Sept. & $\begin{array}{l}\text { Horses. } \\
\text { General agr. }\end{array}$ \\
\hline Boonville..... & Boonville Fair Assn ............ & Local... & 3.l wh. in . In! .... & Do. \\
\hline B rig h t on, & Long Island Kennel Club...... & Interstate & About May 30. & Dogs. \\
\hline $\begin{array}{l}\text { Brockport..... } \\
\text { Bronxville.... }\end{array}$ & Monroe Co. Agl. Soc............ & ("ormty. & Sept... & General agr. \\
\hline Bronx & $\begin{array}{l}\text { Boston Terrier Club, of New } \\
\text { York. }\end{array}$ & & & Dogs. \\
\hline $\begin{array}{l}\text { Brookfield } \\
\text { Brooklyn. }\end{array}$ & Madison Co. Agr. Soc........... & ('oull & From Seyt. 15 to & General agr. \\
\hline $\begin{array}{l}\text { Brookily } \\
\text { Do.. }\end{array}$ & $\begin{array}{l}\text { Bull Terrier Club of America. .. } \\
\text { National Bantam Assn........ }\end{array}$ & International.. & $\begin{array}{l}\text { Spring or fall.... } \\
\text { Dec or Jan }\end{array}$ & Dogs. \\
\hline Do. & Riding and Driving Club of & & 1] & Horses. \\
\hline & $\begin{array}{l}\text { Brooklyn. } \\
\text { Buffalo International Poultry } \\
\text { Show Assn. }\end{array}$ & International.. & $3 \mathrm{~d}$ wk. in Jan.... & Poultry. \\
\hline Do. & $\begin{array}{l}\text { Buffalo Poultry, Pigeon, and } \\
\text { Pet Stock Assn. }\end{array}$ & lo & 3d wk. of Jan.. & $\begin{array}{l}\text { Poultry and } \\
\text { pet stock. }\end{array}$ \\
\hline Cairo. & Greene Co. $\mathrm{Agl}$. Soc............... & C'ount & $\begin{array}{l}\text { Between Aug. } 20 \text { and } \\
30 \text {. }\end{array}$ & General agr. \\
\hline $\begin{array}{l}\text { Cambridge. } \\
\text { Canandaigua }\end{array}$ & Cambridge Valley Agl. Soc.... & International & $3 \mathrm{~d}$ or 4 th wk. in $\mathrm{Aug}$. & Do \\
\hline $\begin{array}{l}\text { Canandal } \\
\text { Do.. }\end{array}$ & $\begin{array}{l}\text { Canandaigua Poultry Assn .... } \\
\text { Ontario Co. Agl. Soc.......... }\end{array}$ & ('ounts & $3 \mathrm{~d}$ wk. in Sept. & $\begin{array}{l}\text { J'oultry. } \\
\text { Generalagr. }\end{array}$ \\
\hline C'anton. & St. Lawrence Co. As & .rlo & .... do.......... & $\begin{array}{l}\text { Generaiagr. } \\
\text { Do. }\end{array}$ \\
\hline $\begin{array}{l}\text { Cape Vincent... } \\
\text { Carmel......... }\end{array}$ & igl. Soc......... & & Last wk. & Do. \\
\hline Ca.tskill........... & $\begin{array}{l}\text { Putnam Co. Fair Assn... } \\
\text { Catskill Poultry Assn... }\end{array}$ & Intereounty..... & About $3 \mathrm{~d}$ wk. in Dec.. & $\begin{array}{l}\text { Do. } \\
\text { Poultry. }\end{array}$ \\
\hline $\begin{array}{l}\mathrm{C} \text { a } \mathrm{t} t \text { araugus } \\
\text { Reservation. }\end{array}$ & 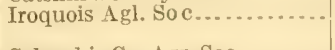 & & Sept................... & General agr. \\
\hline Chatham....... & Columbia Co. Agr. Soc......... & Count & 1st wk. in Sept & Dc \\
\hline Clay tom....... & Thousand Islands Poultry and & Inte & Doturan Toma & $\begin{array}{l}\text { Poultry and } \\
\text { pet stock. }\end{array}$ \\
\hline Clin & American Peony Soc......... & & $\begin{array}{l}\text { Between June } 10 \text { and } \\
25 \text {. }\end{array}$ & Floriculture. \\
\hline $\begin{array}{l}\text { Cohleskill. . . . . } \\
\text { Cohoes....... }\end{array}$ & Cobleskill Agl. Soc........... & Colluty... & Last wk. in Sept & General agr. \\
\hline n... & Otsego Co. Agr. Soc.... & $\ddot{C}_{0}$ & $3 \mathrm{~d}$ wk. of Sept. & General agr. \\
\hline$\cdots$ & Ig Poultry As: & $\mathrm{Nat}$ & $2 \mathrm{~d}$ & Poultry. \\
\hline Co & Cortland Co. Agl. Soc . . . . . . & Inter & Latter par & General agr. \\
\hline & $\begin{array}{l}\text { air and Racing Assn... . . } \\
\text { re Co. Agl. Soc....... . }\end{array}$ & In & Sept.. & $\begin{array}{l}\text { Do. } \\
\text { Do. }\end{array}$ \\
\hline Ieyosil & Deposit Fair Assn....... & & & Do. \\
\hline $\begin{array}{l}\text { De Ruyter.... } \\
\text { Dobbs Ferry... }\end{array}$ & $\begin{array}{l}\text { Four Counties Fair Assn ....... } \\
\text { Dobbs Ferry Horticultural }\end{array}$ & $\begin{array}{l}\text { Intercou } \\
\text { Local. }\end{array}$ & $2 d$ & Do. \\
\hline Dougan Hills... & $\begin{array}{l}\text { Assn. } \\
\text { Richmond Co. Agl. Soc. }\end{array}$ & f'otunt & $\begin{array}{l}\text { Last part of Aug. and } \\
\text { early in Sept. }\end{array}$ & General agr. \\
\hline Iryde & Dryden Agl. Soc & Leveal & $\begin{array}{l}\text { 1st wh. in Sept. before } \\
\text { State fair. }\end{array}$ & Do. \\
\hline & Dundee Fai & lo. & 1st wk. in & Do \\
\hline Ell & $\begin{array}{l}\text { 1a. Co. Ag } \\
\text { Agl. Soc }\end{array}$ & ('ount) & Last wk. & Do. \\
\hline Elmir: & 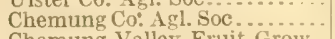 & Intercounty... & Aug & Do. \\
\hline & $\begin{array}{l}\text { Chemung Valley Fruit Grow- } \\
\text { ers' Issn. }\end{array}$ & County....... & middle of & Horticulture. \\
\hline $\begin{array}{l}\text { Fishkill on the } \\
\text { Hutsun. }\end{array}$ & American Rose Soc. . & National & II & Floriculture. \\
\hline & Montgomery Co. Agl. So & County... & About Sept. 30 to Oct. & General aşr. \\
\hline Franklinville... & $\begin{array}{l}\text { Franklinville Agl. and Driv- } \\
\text { ing Park Assn. }\end{array}$ & National.. & Last wk. in A ug & Do. \\
\hline
\end{tabular}

REQUEST.-It is requested that every $1 \mathrm{y}$ who is able to do so will send to this department corrections of errors in this bulletin and additions to the list of fairs and exhibitions. 
TABLE 4.-List of fairs and exhibitions devoted to agriculture, live stock, and other related subjects, by States, 1912-Continued.

NEW YORK-Continued.

\begin{tabular}{|c|c|c|c|c|}
\hline $\begin{array}{l}\text { Place where } \\
\text { held. }\end{array}$ & $\begin{array}{c}\text { Name of fair, exhibition, or } \\
\text { association. }\end{array}$ & Area covered. & $\begin{array}{l}\text { Time when usually } \\
\text { held, or begins, or } \\
\text { range of dates with- } \\
\text { in which it is held. }\end{array}$ & $\begin{array}{l}\text { Kind of } \\
\text { exhibit. }\end{array}$ \\
\hline & Oswego Co. Agri. Soc.... & mimercudinty ... & $3 \mathrm{~d}$ wk. in $\mathrm{Aug}$. & General agr. \\
\hline & ston Poultry Assn...... & & About $2 d$ wk. in Jan.. & Poultry. \\
\hline & $\begin{array}{l}\text { Gouverneur Agl. and Mechl. } \\
\text { Soc. }\end{array}$ & Lo & 1st wk. in Sept........ & General agr. \\
\hline rahamsville. . & Neversink Agl. Soc.......... & ..... d d & Last Wed. in & Do. \\
\hline & de Agl. Soc......... & & 1st & Do. \\
\hline & e Co. Agl. Soc.... & & 1st or $2 \mathrm{~d}$ wh. in Sept... & Do. \\
\hline $\mathrm{H}$ & $\begin{array}{l}\text { Hemlock Lake Union Agl. } \\
\text { Soc. }\end{array}$ & Loca & 1st wk. in Oet.......... & Do. \\
\hline Hempstead . & $\begin{array}{l}\text { Poultry Fanciers' Assn, of L. } \\
\text { I. (Inc.). }\end{array}$ & Interstate... & Early winter.. & Poultry. \\
\hline iv & Herkimer Co. Agl. Soc........ & Cou & Sept.: & General agr. \\
\hline & Hornellsville Fair Assn . . ..... & & Wk. before Labor Day. & Do. \\
\hline & $\begin{array}{l}\text { Steuben - Allegany Poultry } \\
\text { Assn. }\end{array}$ & ........ & $3 \mathrm{~d}$ wk. in Nov....... & Poultry. \\
\hline Hudson & Washington Co. Agl. Soc...... & Intere & About Aug. 27 & General agr. \\
\hline $\mathrm{Hu}$ & Huntington Hort. and Agl. & Lc & June and Sept . & Do. \\
\hline Huntington. & $\begin{array}{l}\text { Huntington Poultry and Pet } \\
\text { Stock Assn. }\end{array}$ & $\ldots . . d c$ & $\begin{array}{l}\text { Middle or last part of } \\
\text { Jan. }\end{array}$ & $\begin{array}{l}\text { Poultry and } \\
\text { pet stock. }\end{array}$ \\
\hline Ithac & Cornell Fruit Exhibit. . & Inter & About Nov. 1. & Horticulture. \\
\hline & Tompkins Co. Agl. and Hort. & & $3 \mathrm{~d} w \mathrm{k}$, in & Gener \\
\hline amesto & Chautauqua Co. Poultry Assn. & & Dec, or Jan. & Poultry. \\
\hline Lit & $\begin{array}{l}\text { Lestershire Poultry Assn..... } \\
\text { Cattaraugus Co. Agl. Soc..... }\end{array}$ & Coun & $2 \mathrm{~d}$ & $\begin{array}{l}\text { Do } \\
\text { General agr. }\end{array}$ \\
\hline Lo & Niagara Co. Agl. Soc......... & $\ldots$ & $\begin{array}{l}\text { Last wk. in Au } \\
\text { 1st wk. in Ser }\end{array}$ & Do. \\
\hline Locust Valley.. & $\begin{array}{l}\text { Piping Rock Horse Show } \\
\text { Assn. }\end{array}$ & & 1st wk. in Oct.. & Horses. \\
\hline ley.. & Piping Rock Kennel Club.... & Loe: & Sep & Dogs. \\
\hline & Co. Agl.So & $\mathrm{Co}$ & wk, in $\mathrm{Au}$ & General agr. \\
\hline & $\begin{array}{l}\text { Wayne Co. Agl. Soc.... } \\
\text { Franklin Co. Agl. Soe... }\end{array}$ & & ... & $\begin{array}{l}\text { Do. } \\
\text { Do. }\end{array}$ \\
\hline & Catskill Mount & In & $\mathrm{L}$ & Do. \\
\hline & Orange Co. Agl. Soc........... & -. & $\begin{array}{l}\text { Wk. preceding Labor } \\
\text { Day. }\end{array}$ & Do. \\
\hline Mineol & $\begin{array}{l}\text { Agricultural Soc. of Queens- } \\
\text { Nassau Cos. }\end{array}$ & & Last wk. in Sept...... & Do. \\
\hline D & $\begin{array}{l}\text { Ladies' K e n n e l Assn. of } \\
\text { America. }\end{array}$ & International. & 1st wk. in June & Dogs. \\
\hline ontic & n Co. Agl. Soc... & & & General agr. \\
\hline & Co. Agl. Corp. . & & wk. & Do. \\
\hline & Fair Assn... & & 1st & Do. \\
\hline & Union Agl. Soc...... & In & Se & Do. \\
\hline & $\begin{array}{l}\text { Rensselaer Co. Agl. and Lib- } \\
\text { eral Arts Soc. }\end{array}$ & & $2 \mathrm{~d}$ & Do. \\
\hline & ark Fair Assn. & & & Do. \\
\hline & gl. Soc...... & & & Do. \\
\hline & $\begin{array}{l}\text { Unadilla Valley Poultry and } \\
\text { Pet Stock Assn. }\end{array}$ & al . & L & Do. \\
\hline & Rockland Co. Industrial Assn. & & & \\
\hline ave & $\begin{array}{l}\text { Westchester and Fairfield } \\
\text { Hort. Soc. }\end{array}$ & Interce & Jur & Horticulture. \\
\hline New Palt & $\begin{array}{l}\text { Ulster Co. Poultry, Pigeon, } \\
\text { and Pet Stock Assn. }\end{array}$ & State & $\begin{array}{l}\text { Latein Dec. or early in } \\
\text { Jan. }\end{array}$ & $\begin{array}{l}\text { Poultry, pi- } \\
\text { geons, and } \\
\text { pet stock. }\end{array}$ \\
\hline Jew Yc & $\begin{array}{l}\text { American Florists and Orna- } \\
\text { mental Hort. Soc. }\end{array}$ & Nati & March or $\Lambda$ pril & Horticulture. \\
\hline Do & $\begin{array}{l}\text { American Institute of the City } \\
\text { of N. Y. }\end{array}$ & & Sept. and Nor & General agr. \\
\hline & $\begin{array}{l}\text { American Land and Irrigation } \\
\text { Expo. }\end{array}$ & Internatio & & Do. \\
\hline & American Pomeranian Club... & & & \\
\hline & C h r y s a n themum Soc. of & Tratornotionol & r $2 \mathrm{~d}$ wk. in & Floricultur \\
\hline & Empire Poultry Assn.... & International & $\begin{array}{l}\text { Full wk. following } \\
\text { Thanksgiving. }\end{array}$ & Poultry. \\
\hline & $\begin{array}{l}\text { French Bull Dog Club of } \\
\text { America. }\end{array}$ & Nation & April. .......... & Dogs. \\
\hline & National Horse Show Assn. of & International. & $\mathrm{Mi}$ & Horses. \\
\hline
\end{tabular}

REQUEST.-It is requested that everybody who is able to do so will send to this department corrections of errors in this bulletin and additions to the list of fairs and exhibitions. 
TABLE 4.-List of fairs and exhibitions devoted to agriculture, live stock, and other related subjects, by States, 1912-Continued.

NEW YORK-Continued.

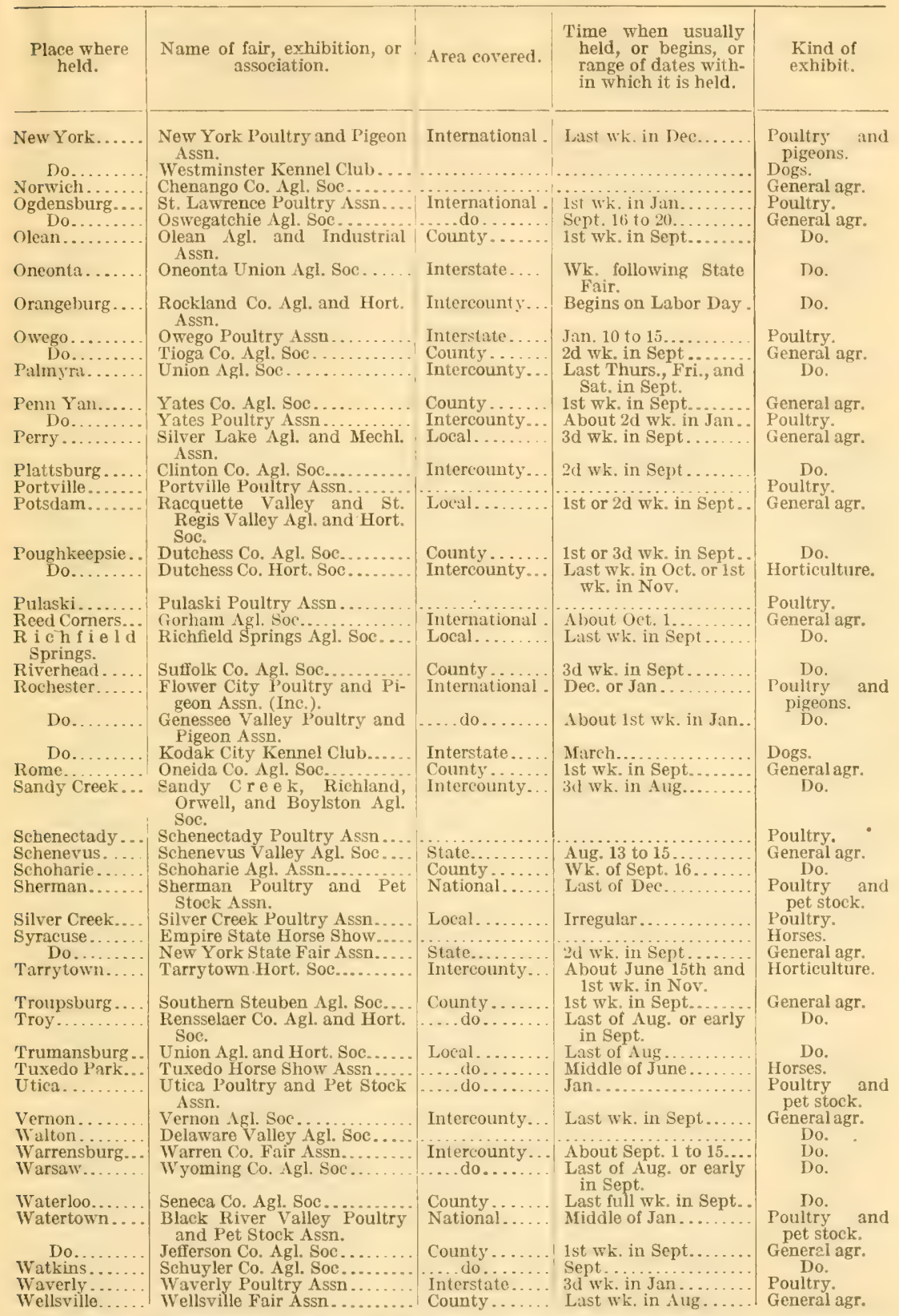

REOUEST.-It is requested that everybody who is able to do so will send to this department corrections of errors in this: bulletin and additions to the list of fairs and exhibitions. 
TABIE 4.-List of fairs and exhibitions devoted to arriculture, live stock, and other related subjects, by States, 1912-Continued.

NEWV YORK-Contiuued.

\begin{tabular}{|c|c|c|c|c|}
\hline $\begin{array}{l}\text { Place where } \\
\text { held. }\end{array}$ & $\begin{array}{c}\text { Name of fair, exhibilion, or } \\
\text { association. }\end{array}$ & Area covered. & $\begin{array}{l}\text { Time when usually } \\
\text { held, or begins, or } \\
\text { range of dates with- } \\
\text { in which it is held. }\end{array}$ & $\begin{array}{l}\text { Kind of } \\
\text { exhibit. }\end{array}$ \\
\hline Testchester. & Northern Nut Growers' Assn.. & Interstate & Fall. & Horticultuv \\
\hline Test Phoenix. - & Onondaga Co. Fair Assn ..... & & $\begin{array}{l}\text { Bet. Aug. } 20 \text { and } \\
\text { Sept. } 1 .\end{array}$ & General agr. \\
\hline estport. & Essex Co. Agl. Soc............... & County. & About Sept. 1........ & Do. \\
\hline $\begin{array}{c}\text { rhite Plains... } \\
\text { Do........... }\end{array}$ & $\begin{array}{l}\text { Westchester Co. Agl. and Hort. } \\
\text { Soc. } \\
\text { Westchester Horse Show...... }\end{array}$ & & ................ & $\begin{array}{l}\text { Do. } \\
\text { Horses. }\end{array}$ \\
\hline hitneys Point & Broome Co. Agl. soc........... & County & $2 \mathrm{~d}$ or $3 \mathrm{~d}$ wk. il Aug... & General agr. \\
\hline onkers....... & Yonkers Hort. Soe........... & Intercounty & $\begin{array}{l}\text { Middle of June and } \\
\text { last wk. in Oct. }\end{array}$ & Horticulture. \\
\hline
\end{tabular}

\section{NORTH CAROIINA.}

\begin{tabular}{|c|c|c|c|c|}
\hline 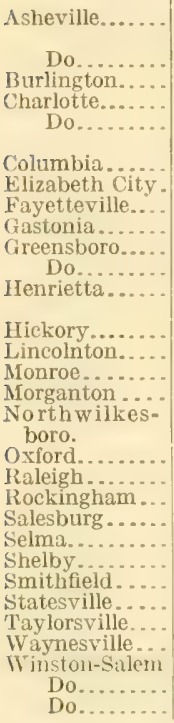 & 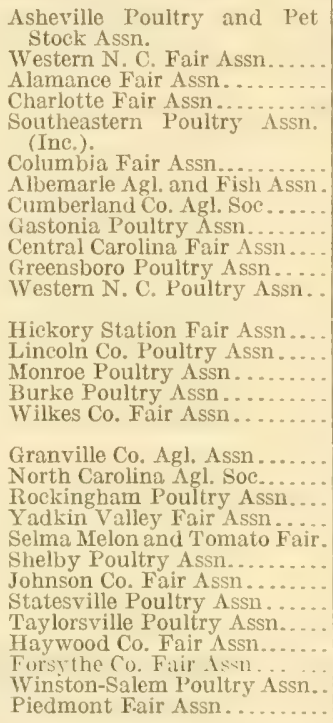 & 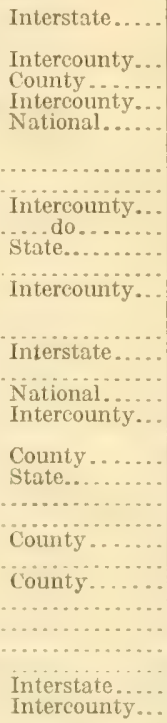 & 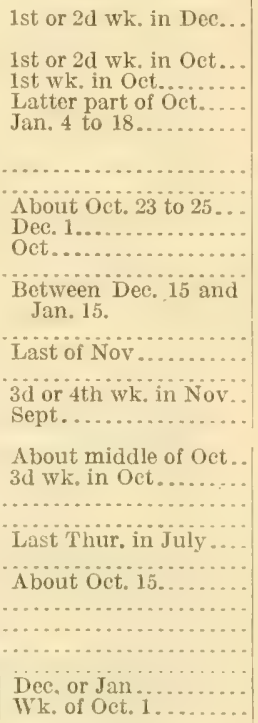 & $\begin{array}{l}\text { Poultry and } \\
\text { pet stock. } \\
\text { Generalagr. } \\
\text { Do. } \\
\text { Do. } \\
\text { Poultry. } \\
\text { General agr. } \\
\text { Do. } \\
\text { Do. } \\
\text { Poultry. } \\
\text { General agr. } \\
\text { Poultry. } \\
\text { Do. } \\
\text { General agr. } \\
\text { Poultry. } \\
\text { Do. } \\
\text { Do. } \\
\text { General agr. } \\
\text { Do. } \\
\text { Do. } \\
\text { Poultry. } \\
\text { Generalagr. } \\
\text { Do. } \\
\text { Poultry. } \\
\text { Generalagr. } \\
\text { Poultry. } \\
\text { Do. } \\
\text { General agr. } \\
\text { Do. } \\
\text { Poultry. } \\
\text { Generalagr. }\end{array}$ \\
\hline
\end{tabular}

NORTH DAKOTA.

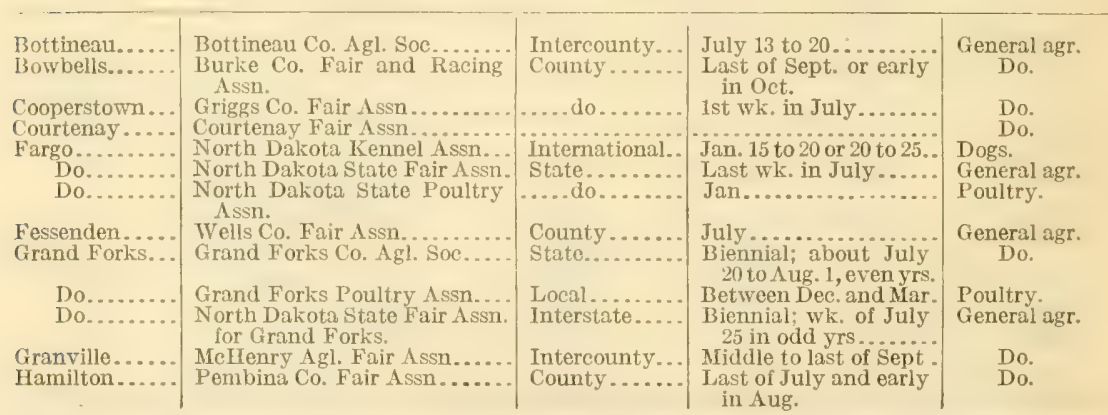

REQUEST.-It is requested that everybody who is able to do so will send to this department corrections of errors in this bulletin and additions to the list of fairs and exhibitions. 
TABLE 4.-List of fairs and exhibitions devoted to agriculture, live stock, and other related subjects, by States, 1912-Continued.

NORTH DAKOTA-Continued.

\begin{tabular}{|c|c|c|c|c|}
\hline $\begin{array}{l}\text { Place where } \\
\text { held. }\end{array}$ & $\begin{array}{c}\text { Name of fair, exhibition, or } \\
\text { association. }\end{array}$ & Area covered. & $\begin{array}{l}\text { Time when usually } \\
\text { held, or begins, or } \\
\text { range of dates with- } \\
\text { in which it is held. }\end{array}$ & $\begin{array}{l}\text { Kind of } \\
\text { exhibit. }\end{array}$ \\
\hline 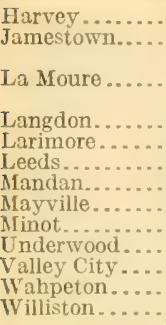 & 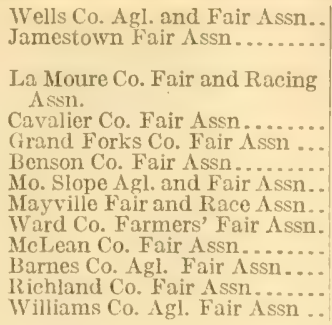 & 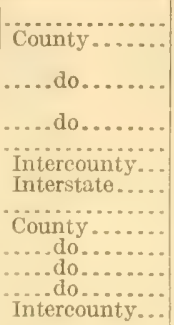 & 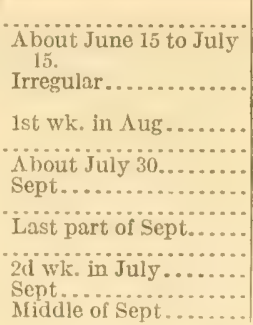 & $\begin{array}{l}\text { General agr. } \\
\text { Do. } \\
\text { Do. } \\
\text { Do. } \\
\text { Do. } \\
\text { Do. } \\
\text { Do. } \\
\text { Do. } \\
\text { Do. } \\
\text { Do. } \\
\text { Do. } \\
\text { Do. } \\
\text { Do. }\end{array}$ \\
\hline
\end{tabular}

OHIO.

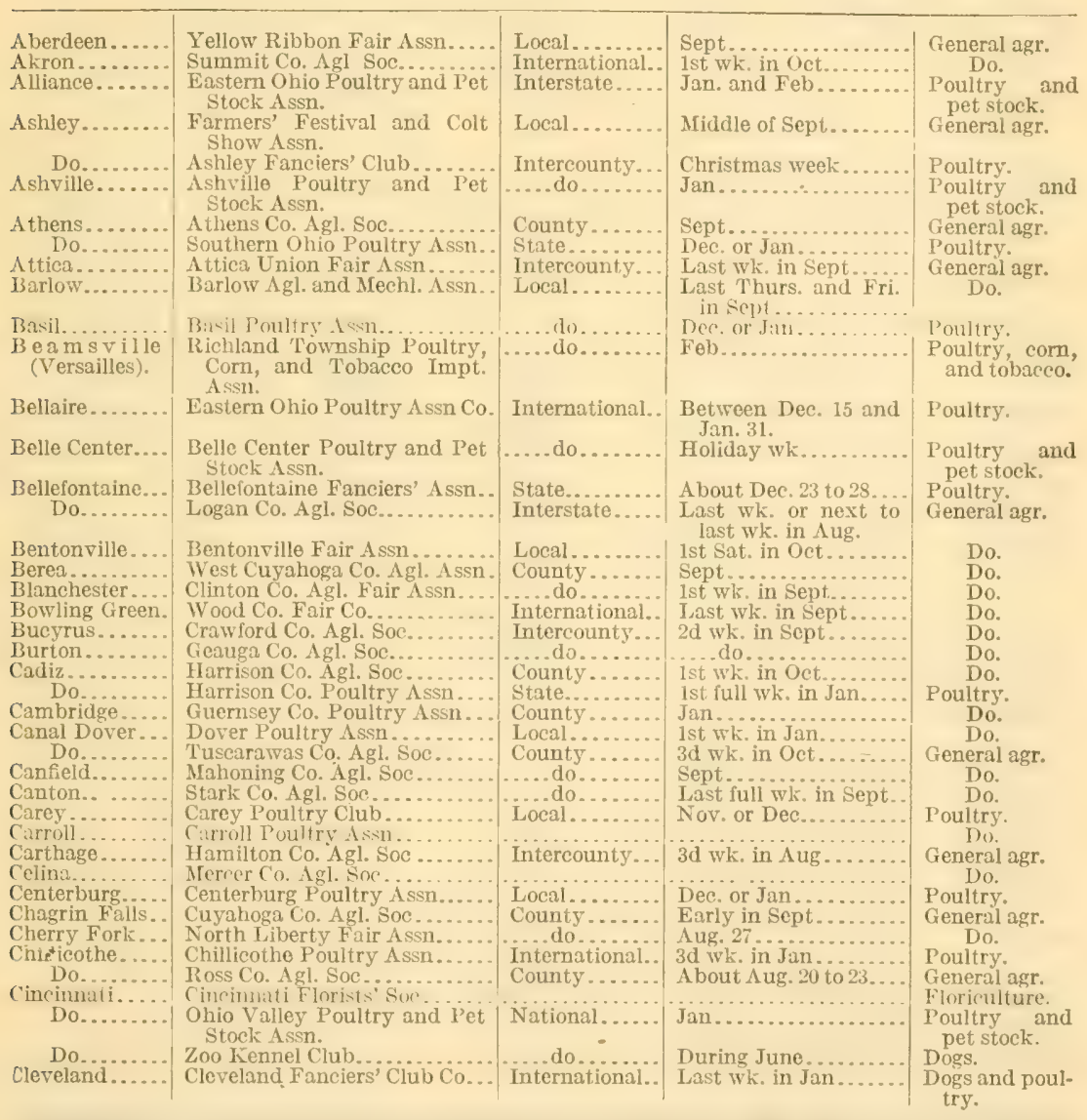

REQUEST.-It is requested that everybody who is able to do so wili send to this department corrections of errors in this bulletin and additions to the list of fairs and exhibitions. 
TABLE 4.-List of fairs and exhibitions devoted to agriculture, live stock, and other related subjects, by States, 1912-Continued.

OHIO-Continued.

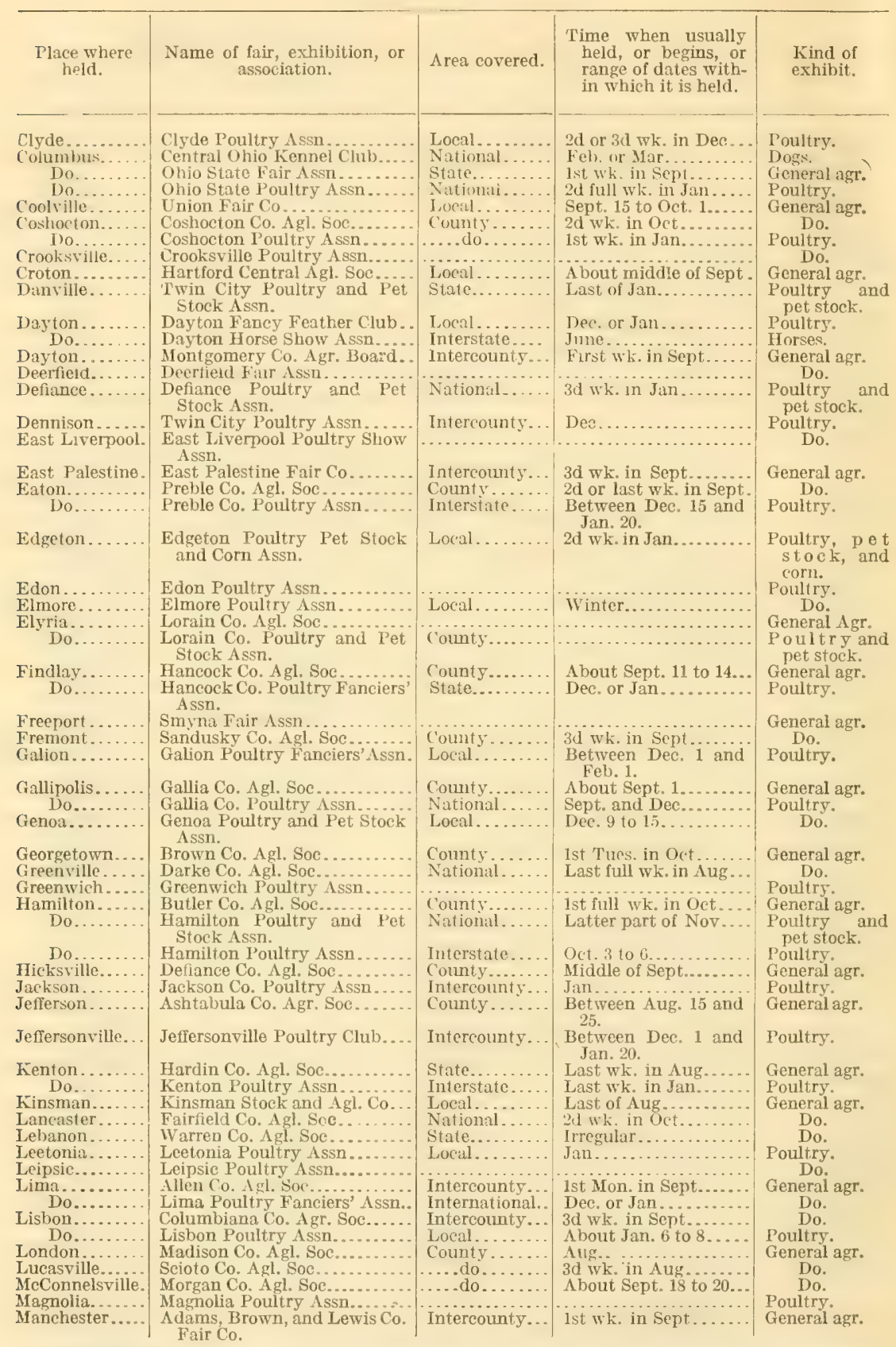

REQUEST. It is requested that everybody who is able to do so will send to this department corrections of errors in this bulletin and additions to the list of fairs and exhibitiong. 
TABLE 4.-List of fairs and exhibitions devoted to arriculture, live stock, and other related subjects, by States, 1912-Continued.

OHIO-Continued.

\begin{tabular}{|c|c|c|c|c|}
\hline $\begin{array}{l}\text { Place where } \\
\text { held. }\end{array}$ & $\begin{array}{l}\text { Name of fair, exhibition, or } \\
\text { association. }\end{array}$ & Area covered. & $\begin{array}{l}\text { Time when usually } \\
\text { held, or begins, or } \\
\text { range of dates with- } \\
\text { in which it is held. }\end{array}$ & $\begin{array}{l}\text { Kind of } \\
\text { exhibit. }\end{array}$ \\
\hline Mansficle & Mansfield Fanciers' As & Interstat & 1st full wk. in Dec.... & Poutry. \\
\hline 1) 0 . . & Riebland Co. Agl. Soc... & County. & 1st wk. in Sept... & General agr. \\
\hline Marietta. & Ohio Valley Poultry $\AA$ ssin... & local... & Jan ............. & Poultry. \\
\hline$\cdots$ & $\begin{array}{l}\text { Washington Co. } \Lambda \text { gl. and } \\
\text { Mfechl. } \Lambda \text { ssn. }\end{array}$ & National. & Sept..... & General agr. \\
\hline Marion & Marion Co. Agl. Assn . . . . . . . . & National & Last wh. in Sept & Do. \\
\hline Do. & Marion Poultry Assn.......... & Intersta & Last wk. in Nov. & I'oultry. \\
\hline Marlhoro. & $\begin{array}{l}\text { Marlboro Poultry and Corn } \\
\text { Assn. }\end{array}$ & Local.. & $3 \mathrm{~d}$ or 4 th wh. in Dec. & $\begin{array}{l}\text { Poult ry and } \\
\text { corn. }\end{array}$ \\
\hline Marys & Union Co. Agl. Soc............ & County & 1st wk. in Sept & General agr. \\
\hline Massillon. & Massillon Poultry Assn..... & & & try. \\
\hline Medina........ & Medina Co. Agl. Soc........... & Co & About ist wk. in Sept. & General agr. \\
\hline Do. & $\begin{array}{l}\text { Medina Co. Poultry and Pet } \\
\text { Stock Assn. }\end{array}$ & $\ln t$ & $2 d$ wk. in Dec.. & $\begin{array}{l}\text { Poultry and } \\
\text { pet stock. }\end{array}$ \\
\hline Milan.......... & $\begin{array}{l}\text { Milan Poultry and Pet Stock } \\
\text { Assn. }\end{array}$ & County & Dece or Jinll. & Do. \\
\hline Monticello..... & $\begin{array}{l}\text { White Co. Poultry and Pet } \\
\text { Stock Assn. }\end{array}$ & Intercount $y . .$. & 2d wk.in Jan..... & Do. \\
\hline Montpelier..... & WVilliams Co. Agl. Soc........ & Cou & $2 \mathrm{~d} w h$ & General agr. \\
\hline 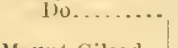 & $\begin{array}{l}\text { Williams Poultry and Pet } \\
\text { Stock Assn. }\end{array}$ & $\mathrm{Co}$ & Dec & $\begin{array}{l}\text { Poultry and } \\
\text { pet stock. }\end{array}$ \\
\hline Mount Gilead.. & Morrow Co. Agl. Soc. . ....... & & 1st wh, i & General agr. \\
\hline Mount Vernon.! & Knox (o. Agl, Soc . . . . . . . . & Intercout & Sept.... & Do. \\
\hline Do........ & $\begin{array}{l}\text { Knox Co. Poultry and l'et } \\
\text { Stoek Assn. }\end{array}$ & St & Dee. or $\mathrm{J}$ & $\begin{array}{l}\text { Poultry and } \\
\text { pet stock. }\end{array}$ \\
\hline Napoleon....... & $\begin{array}{l}\text { Napoleon Fair Co.............. } \\
\text { Nelsonville Poultry Assn. }\end{array}$ & Cour & 1st wk. in Sept.. & General agr. \\
\hline $\begin{array}{l}\text { Neison } \\
\text { Newarl }\end{array}$ & Licking Co. Agl. Soc... & Intercou & 1st wk. in & Fentry. \\
\hline Do. & Newark Kennel Club.. & & . & Dogs. \\
\hline $\begin{array}{l}\text { New Bremen... } \\
\text { New Lexington. }\end{array}$ & Tri-Co. Fair Assn ....... & & & General agr. \\
\hline & $\begin{array}{l}\text { Co. Agl. Soc........ } \\
\text { on Poultry Assu.... }\end{array}$ & $\mathrm{Co}$ & $\begin{array}{l}3 \mathrm{~d} \text { or } 4 \text { th wk. } \\
\text { Dee. or Jan. }\end{array}$ & Do. \\
\hline Norwalk....... & Norwalk Poultry Assn.... & & 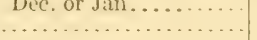 & $\begin{array}{l}\text { Poultry. } \\
\text { Do. }\end{array}$ \\
\hline Nittwood..... & Nutwood Live Stock Assn... & & . & Live stock. \\
\hline $\begin{array}{l}\text { Old Washing- } \\
\text { ton. }\end{array}$ & Guernsey Co. Agl. Soc........ & & La & General agr. \\
\hline Uttawa.: & $I^{\prime}$ & In & 1st Tuc & \\
\hline $\begin{array}{l}. . \\
\ldots\end{array}$ & $\begin{array}{l}\text { Clermont Co. Agl. Soc. } \\
\text { Paulding Co. Agl. Soc. }\end{array}$ & & $3 d$ & $\begin{array}{l}\text { Do. } \\
\text { Do. }\end{array}$ \\
\hline I'echles & Peebles Fair Co...... & & $6 . .$. & Do. \\
\hline Pember & Pemberville Poultry Ass & un & an.. & Poultry. \\
\hline$\cdots$ & Pike Co. Agl. Soc............ & & 2 & General agr. \\
\hline $\begin{array}{l}\text { Picpua... } \\
\text { l'ow'll.. }\end{array}$ & Miama Poultry Fanciers'Assn. & $\begin{array}{l}\text { Nati } \\
\text { Coun }\end{array}$ & 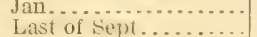 & $\begin{array}{l}\text { Poultry. } \\
\text { General ag. }\end{array}$ \\
\hline Proctory & $\begin{array}{l}\text { Lawrence Co. Agl and Hort. } \\
\text { Soc. }\end{array}$ & ..... dio. & $\begin{array}{l}\text { Last of Aug. or early in } \\
\text { Sept. }\end{array}$ & Do. \\
\hline Raven & Portage Co. Agl. Soc.... & Int & $2 \mathrm{~d} w \mathrm{w}$. in & Do. \\
\hline$\cdots$ & ri-Co. Fair Co..... & - & Ist wk. in & Do. \\
\hline & Ripley Fair & & $\begin{array}{l}4 \text { days beginning ist } \\
\text { Tues. in Aug. }\end{array}$ & \\
\hline ngs.. & Meig. & & 1st or $2 \mathrm{~d} y$ & $\mathrm{D}$ \\
\hline$\ldots$ & $\begin{array}{l}\text { Romle Fair } \\
\text { Buckeve } 1\end{array}$ & & A & $\begin{array}{l}\text { Do. } \\
\text { l'oult }\end{array}$ \\
\hline ssell & $\begin{array}{l}\text { Buckeye Poultry Assn........ } \\
\text { Russellville Grange Fair Assn. }\end{array}$ & $\begin{array}{l}\text { Intercount } \\
\text { Local..... }\end{array}$ & $\begin{array}{l}\text { 1st or } 2 d \text { wh. in Jan. } \\
\text { Thurs., } 2 d \text { full wk. in } \\
\text { Oct. }\end{array}$ & $\begin{array}{l}\text { Poultry. } \\
\text { General agr. }\end{array}$ \\
\hline ille. . & Belmo & In & Abou & Do. \\
\hline (n) & $\begin{array}{l}\text { Salem Poultry and Pet Stock } \\
\text { Assn. }\end{array}$ & Ir & $\begin{array}{l}\text { Wk. preceding Christ- } \\
\text { mas. }\end{array}$ & $\begin{array}{l}\text { Poultry and } \\
\text { pet stock. }\end{array}$ \\
\hline Sanclu & Co. - & & $\begin{array}{l}\text { Al } \\
2 d\end{array}$ & $\begin{array}{l}\text { General agr. } \\
\text { Do. }\end{array}$ \\
\hline s: & Kennedys Fair Assi & & & $\begin{array}{l}\text { Do. } \\
\text { Do. }\end{array}$ \\
\hline Shelly & Shelby Poultry Ass & $\mathrm{L}$ & Midd & I'oultry. \\
\hline Sidne & Shelby Co. Agl. Soc... & Cou & $2 \mathrm{~d}$ wk. in & General agr. \\
\hline $\begin{array}{l}\text { Simithfi } \\
\text { somerse }\end{array}$ & $\begin{array}{l}\text { Jefferson Co. Agl. Soc. } \\
\text { Perry Co. Live Stock, }\end{array}$ & cal. & $\begin{array}{l}\text { About Sept. } 25 \text { to } 27 . . \\
3 \mathrm{~d} \text { wh. in Oct......... }\end{array}$ & \\
\hline & Art Union Soc. & & & $\mathrm{T} \Omega$ \\
\hline Springf & Clark Co. Agl. Soc. . . . . . . . . & $\begin{array}{l}\text { National. } \\
\text { Internatic }\end{array}$ & 1st wh. in Aug. & $\begin{array}{l}\text { Do. } \\
\text { ses. }\end{array}$ \\
\hline & $\begin{array}{l}\text { Springfield Horse Show Co. } \\
\text { (Inc.). }\end{array}$ & & & Horses. \\
\hline & $\begin{array}{l}\text { Springfield Poultry and Pet } \\
\text { Stock } \Lambda \text { ssn. }\end{array}$ & & & $\begin{array}{l}\text { Poultry and } \\
\text { pet stock. }\end{array}$ \\
\hline Summe & $\begin{array}{l}\text { Struthers Poultry Assn. } \\
\text { Summerfield Fair Assn. }\end{array}$ & & & $\begin{array}{l}\text { Poultry. } \\
\text { General agr. }\end{array}$ \\
\hline
\end{tabular}

REQUEST.-It is requested that everybody who is able to do so will send to this department corrections of errors in this bulletin and additions to the list of fairs and exhibitions. 
TABLE 4.-List of fairs and exhibitions devoted to arriculture, live stock, and other related subjects, by States, 1912-Continued.

OHIO-Continuerl.

\begin{tabular}{|c|c|c|c|c|}
\hline $\begin{array}{l}\text { Place where } \\
\text { held. }\end{array}$ & $\begin{array}{c}\text { Name of fair, exhibition, or } \\
\text { association. }\end{array}$ & Area covered. & $\begin{array}{l}\text { Time when usually } \\
\text { held, or begins, or } \\
\text { range of dates with- } \\
\text { in which it is held. }\end{array}$ & $\begin{array}{l}\text { Kind of } \\
\text { exhibit. }\end{array}$ \\
\hline Sycamore & Sycamore Fair Assu... & & & General agr. \\
\hline Tiffin. & $\begin{array}{l}\text { Northwestern Ohio Poultry } \\
\text { Assn. }\end{array}$ & Intercounty. & 2d wk. in Jan... & l'oultry. \\
\hline Do. & Seneca Co. Agl. Soc........... & County........ & 1st wk. in Sept.. & Goneral agr. \\
\hline 'Toledo. & Lucas Co. Agl. Soc............... & Interstate..... & $2 d$ wk. in Sept... & Do. \\
\hline Do & Tri-State Poultry and Pet & $\ldots . .$. do.... & 2d wk. in Jan. & $\begin{array}{l}\text { Poultry and } \\
\text { pet stock. }\end{array}$ \\
\hline $\begin{array}{l}\text { Troy............ } \\
\text { Tuscarawas... }\end{array}$ & $\begin{array}{l}\text { Miami Co. Agl. Soc.......... } \\
\text { Tuscarizwas l'oultry Assn.. }\end{array}$ & & & Géneral agr. \\
\hline Upper San- & Upper Sandusky Poultry Assn. & County & 1st wh. in Jan & Do. \\
\hline Do... & Wyandot Agl. and Fair $\Lambda$ ssn . & ..... do. & Tues, nearest middle & General agr. \\
\hline Urbana & Champaign Co. Agl & ... & About 3 d wk. in Aug.. & D \\
\hline Van lVe. & $\begin{array}{l}\text { Urbana Youltry Assn.. } \\
\text { Van wert Co. Agl. Soc }\end{array}$ & & & Poultry \\
\hline Do... & Van Wert Fanciers' Club...... & Interstate & Dec. 15 to Jan. 15 . & $\begin{array}{l}\text { General agr. } \\
\text { Poultry. }\end{array}$ \\
\hline Vadsworth... & Wadsworth Poultry Assn ..... & Local.... & $3 \mathrm{~d}$ wk. in Jan.... & \\
\hline Taker & Wakeman Poultry Assn. & ....do... & Jan. or Fel,... & \\
\hline ... & C Co. $\mathrm{Agl}$. Soc... & Col & Aug. 27 to 3 & General agr. \\
\hline Washington & Fayette Co. Fair Co... & 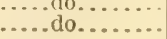 & $\begin{array}{l}\text { Ist WK. In sept......... } \\
\text { Last of } A \text { ug . . . . . . . }\end{array}$ & $\begin{array}{l}\text { Do. } \\
\text { Do }\end{array}$ \\
\hline C. II. & 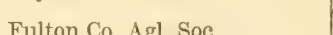 & & & \\
\hline Wauseon...... & Miami Valley Poultry Ass? & Intercou & $\begin{array}{l}\text { WK. of Sept. } 20 . . \\
\text { Last of Dec. or earl }\end{array}$ & $\begin{array}{l}\text { General agr. } \\
\text { Poultry. }\end{array}$ \\
\hline Wellington & $\begin{array}{l}\text { Wellington Poultry Fanciers' } \\
\text { Club. }\end{array}$ & Lo & 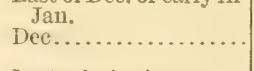 & Do. \\
\hline Do... & Wellington Union Agl. Soc... & .. & Last wk. in $\mathrm{Au}$ & General agr. \\
\hline $\begin{array}{l}\text { West Alexan- } \\
\text { dria. }\end{array}$ & West Alexandria Poultry & & $\cdots$ & Poultry. \\
\hline West Mansfield & West Mansfield Horse Show... & & & Horse \\
\hline $\begin{array}{l}\text { West Union.... } \\
\text { TVinchester.... }\end{array}$ & Adams Co. Agl. Soc............. & Int & $2 d n$ & Gemeril agr. \\
\hline $\begin{array}{l}\text { W1 } \\
\text { Wo }\end{array}$ & $\begin{array}{l}\text { Winchester Fair Assn.. } \\
\text { Monroe Co. Agl. Soc.... }\end{array}$ & & Au & Do. \\
\hline dville & $\begin{array}{l}\text { Woodville Poultry and Pet } \\
\text { Stock Assn. }\end{array}$ & State... & $\begin{array}{l}\text { Last wk, in Jan, or Ist } \\
\text { wh. in Feb. }\end{array}$ & $\begin{array}{l}\text { Poultry and } \\
\text { pet stock. }\end{array}$ \\
\hline Wooste & Wayne Co. Agr. Soc... & Intercount & About Sept. 11 to $13 .$. & General agr. \\
\hline Do. & Wooster Poultry Assn. & County.... & $2 \mathrm{~d}$ wk. in Jan......... & Poultry. \\
\hline Tenia. & Greene Co. Agl. Soc.. & ....do. do. & $2 d$ wk. in ling... & General agr. \\
\hline $\begin{array}{l}\text { Do. } \\
\text { Youngst }\end{array}$ & $\begin{array}{l}\text { Xenia Fanciers' Club.......... } \\
\text { Youngstown Fanciers' Club.. }\end{array}$ & $\begin{array}{l}\text { Intercoun } \\
\text { Interstate }\end{array}$ & $\begin{array}{l}\text { Doe. or Jan ...... } \\
\text { al wh. in Dec.... }\end{array}$ & $\begin{array}{l}\text { Poultry. } \\
\text { Do. }\end{array}$ \\
\hline Zanesville & Muskingum Co. $\Lambda \mathrm{gl}$. Soc..... & Intercount & ling or sept. & General agr. \\
\hline & Zanesville Fanciers' Assn. Co.. & International.. & Last wk. in Jan.. & Poultry. \\
\hline
\end{tabular}

OKLAHOMA.

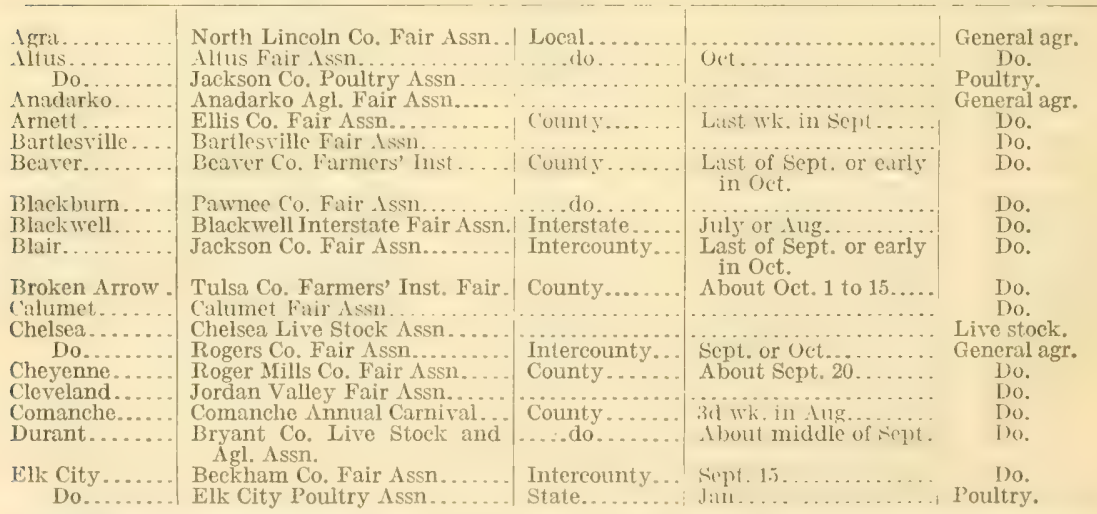

IREQUEST.-It is requested that everybody who is able to do so will send to this department corrections of errors in this bulletin and additions to the list of fairs and exhibitions. 
TABLE 4.-List of fairs and exhibitions devoted to agriculture, live stock, and other related subjects, by States, 1912-Continued.

OKLAHOMA-Continued.

\begin{tabular}{|c|c|c|c|c|}
\hline $\begin{array}{l}\text { Place where } \\
\text { held. }\end{array}$ & $\begin{array}{l}\text { Name of fair, exhibition, or } \\
\text { association. }\end{array}$ & Area covered. & $\begin{array}{l}\text { Time when usually } \\
\text { held, or begins, or } \\
\text { range of dates with- } \\
\text { in which it is held. }\end{array}$ & $\begin{array}{l}\text { Kind of } \\
\text { exhibit. }\end{array}$ \\
\hline El Reno & Canadian Co. Poultry Assn.... & County. & rast of De & oults \\
\hline & El Reno and So. Western Fair & & Last of Sept.... & General agr. \\
\hline Enid. & Big Center Poultry and Pet & & Dec. or Jan... & Poultry and \\
\hline Do.. & Enid Fair and Live Stock & National. & Dec. and March.. & General agr. \\
\hline Erick... & Erick Dist. Fair Assn......... & Local. & $\begin{array}{l}\text { Between Aug. } 15 \text { and } \\
\text { Sept. } 15 \text {. }\end{array}$ & Do. \\
\hline Fredericl & Tillman Co. Fair Assn & & & Do. \\
\hline Hallett. & Pawnee Co. Fair Assn... & Count & Early in Oet & Do. \\
\hline $\mathrm{He}$ & Woods Co. Fair Assn.... & & & Do. \\
\hline $\begin{array}{l}\text { Hinton } \\
\text { Hobart }\end{array}$ & $\begin{array}{l}\text { Hinton Fair Assn } \\
\text { So. Western Okla. Fair Assn. }\end{array}$ & Lo & About Sept. 20. & $\begin{array}{l}\text { Do. } \\
\text { Do. }\end{array}$ \\
\hline Do & $\begin{array}{l}\text { Southwest Okla. Poultry and } \\
\text { Pet Stock Assn. }\end{array}$ & Interstate & Dec & $\begin{array}{l}\text { Poultry and } \\
\text { pet stock. }\end{array}$ \\
\hline Hugo. & Choctaw Fair Assn...... & Count & About Sept. 11 to $14 . .$. & General agr. \\
\hline $\mathrm{H}$ & Hugo Fair Assn.. & Intercol & $\begin{array}{l}\text { Between Sept. } 15 \text { and } \\
\text { Oct. } 5 \text {. }\end{array}$ & Do. \\
\hline Hydro & $\begin{array}{l}\text { Hydro. Agl. and Live stock } \\
\text { Assn. }\end{array}$ & & & Do. \\
\hline & $\begin{array}{l}\text { Hydro Poultry and Pet Stock } \\
\text { Assn. }\end{array}$ & Loeal & 1st wh. in De & $\begin{array}{l}\text { Poultry and } \\
\text { pet stock. }\end{array}$ \\
\hline Kingfisher & Kingfisher Co, Agl. Fair Assn. & & & General agr. \\
\hline $\begin{aligned} & \text { Do } \\
& \text { Mangux }\end{aligned}$ & Kingfisher Poultry Assn....... & & & Poultry. \\
\hline Musko & Muskogee Horse Show Assn... & & & Horses. \\
\hline Do & Muskogee Poultry Assn . ...... & $\mathrm{Ne}$ & Dec & Poultry. \\
\hline D & New State Fair Assn..... & State.. & $2 \mathrm{~d}$ wk. in Oet & General agr. \\
\hline$\cdots \cdots$ & 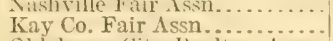 & $\mathrm{Co}$ & & $\begin{array}{l}\text { Do. } \\
\text { I). }\end{array}$ \\
\hline Oklahoma City. & Oklahoma City I'oultry Assn. & & & Poultry. \\
\hline Do. & State Fair Assn. of Oklahoma. & Ste & $\begin{array}{l}\text { Last wk. in Sept. or } \\
\text { 1st wk. in Oct. }\end{array}$ & General agr. \\
\hline $\begin{array}{l}\text { Pawhus } \\
\text { Perry. }\end{array}$ & Osage Co. Fair Assn.... & & & \\
\hline Shattuch & Ellis Co Poultry and Pet & Co & Dec. 1 to 2 & Poultry and \\
\hline Shawne & $\begin{array}{l}\text { Pottawatomie Co. Fanciers' } \\
\text { Assn. }\end{array}$ & & De & Poultry. \\
\hline Ster & Sterling Fair Assn .............. & $\mathrm{Lo}$ & $3 d$ & General agr. \\
\hline Still & $\begin{array}{l}\text { Eastern Okla. Poultry and } \\
\text { Pet Stock Fair Assn. }\end{array}$ & In & Jan & $\begin{array}{l}\text { Poultry and } \\
\text { pet stock. }\end{array}$ \\
\hline Do. & $\begin{array}{l}\text { Payne Co. Agl. and Stock Fair } \\
\text { Assn. }\end{array}$ & Cour & $\Lambda$ bout $\mathrm{Oc}$ & Géneral agr. \\
\hline . & Sulphur Poultry Assn & & & Poult I \\
\hline TuIsa & Eastern Okla. Poultry Assn... & International.. & 1 st $v$ & \\
\hline$\because$ & 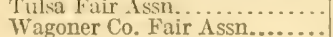 & $\begin{array}{l}\text { Interstato } \\
\text { County }\end{array}$ & $\begin{array}{l}\text { Sept } \\
\text { Oct. }\end{array}$ & General agr. \\
\hline II & $\begin{array}{l}\text { Blaine Co. Fair and Live } \\
\text { Stock Assn. }\end{array}$ & & About Aug. 1. & Do. \\
\hline Waynoka. & $\begin{array}{l}\text { Waynoka Poultry and Pet } \\
\text { Stock Assn. }\end{array}$ & International.. & Late winter & $\begin{array}{l}\text { Poultry and } \\
\text { pet stoek. }\end{array}$ \\
\hline lerford. & Custer Co. Fair Assn .......... & Intert & Latter liart of Sept & feneral agr. \\
\hline W & $\begin{array}{l}\text { Northwest Okla. Poultry and } \\
\text { Pet Stock Assn. }\end{array}$ & & Dec. or Jan....... & $\begin{array}{l}\text { Poultry and } \\
\text { pet stock. }\end{array}$ \\
\hline Do. & Woodward Co. Fair. . & Intercounty. & About sept. 10 to $13 . .$. & General agr. \\
\hline
\end{tabular}

OREGON.

\begin{tabular}{|c|c|c|c|c|}
\hline $\begin{array}{l}\text { Astoria. ........ } \\
\text { Baker......... }\end{array}$ & $\begin{array}{l}\text { Lower Columbia Agl. Co...... } \\
\text { Baker Co. Fair Assn......... }\end{array}$ & $\begin{array}{l}\text { Interstate...... } \\
\text { County....... }\end{array}$ & $\begin{array}{l}\text { Sept. } 10 \text { to } 25 . . . . . . . \\
\text { About middle to end } \\
\text { of Sept. }\end{array}$ & $\begin{array}{l}\text { General agr. } \\
\text { Do. }\end{array}$ \\
\hline $\begin{array}{l}\text { Burns........... } \\
\text { Corvallis..... }\end{array}$ & Harney Co. Fair Assn......... & & 1st $w \mathrm{k}$, in Oct....... & $\underset{H}{\mathrm{D}}$ \\
\hline Enterprise. & $\begin{array}{l}\text { 1st Eastern Oreg. Dist. Agl. } \\
\text { Soc. }\end{array}$ & Intercount & $\begin{array}{l}\text { Last of Sept. and early } \\
\text { in Oct. }\end{array}$ & General agr. \\
\hline $\begin{array}{l}\text { Eugene......... } \\
\text { Do......... } \\
\text { Do....... }\end{array}$ & $\begin{array}{l}\text { Lane Co. Apple Show Assn... } \\
\text { Lane Co. Fair Assn........... } \\
\text { Lane Co. Poultry Assn........ }\end{array}$ & $\begin{array}{l}\text { County ... } \\
\text { Interstate. }\end{array}$ & 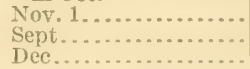 & $\begin{array}{l}\text { Horticulture. } \\
\text { General agr. } \\
\text { Poultry. }\end{array}$ \\
\hline
\end{tabular}

REQUEST.-It is requested that everybody who is able to do so wili send to this department corrections of errors in this bulletin and additions to the list of fairs and exhibitions. 


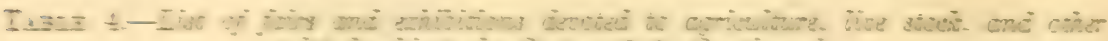

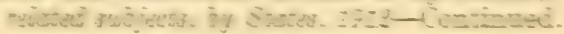

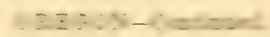

\begin{tabular}{|c|c|c|c|c|}
\hline 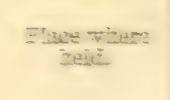 & 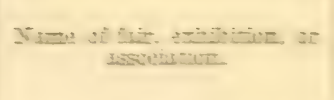 & 1-ua curnos: & 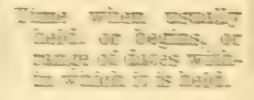 & $\begin{array}{ll}E=2 \\
e x\end{array}$ \\
\hline E-reses. & 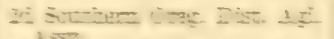 & E-raceton: & 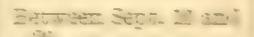 & - \\
\hline Inest & WIS- & $\therefore=$ & $x-7$ or $=0$ & Pután. \\
\hline$=200=x$ & 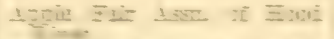 & & 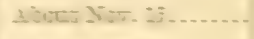 & Erriviones. \\
\hline Dive =1\%. & 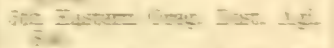 & $\ldots+1 . .+8$ & 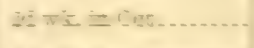 & Geteri ap. \\
\hline Ii Imantit & 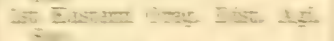 & 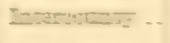 & 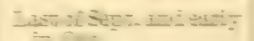 & $D *$ \\
\hline Wis - - - IE- & 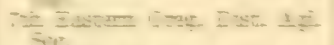 & 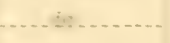 & chet.t. te th. & 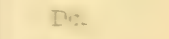 \\
\hline Ii:rs. & 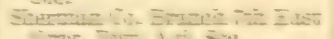 & Coun= & $\operatorname{cosen} 2: 200$ & $1+$ \\
\hline Mratzorivers & 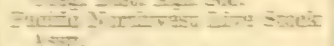 & Ener & 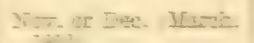 & 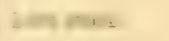 \\
\hline Earietic... & 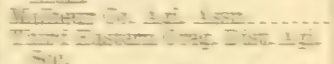 & - & $35 \mathrm{sic}=5$ & $\log _{0-2}$ \\
\hline 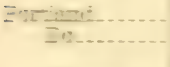 & 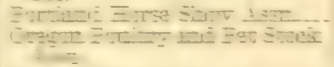 & $=$ & -2 & 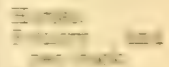 \\
\hline 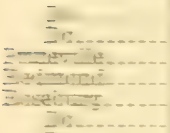 & 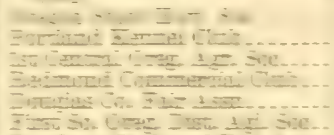 & …ㄹ. & 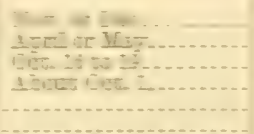 & 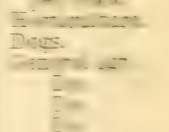 \\
\hline$\Rightarrow=n$ & Easecter = & - & 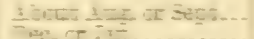 & $=$ \\
\hline$-2 x=2$ & ore & None & 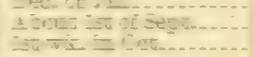 & zes \\
\hline
\end{tabular}

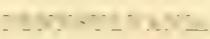

\begin{tabular}{|c|c|c|c|c|}
\hline$\frac{17 x+20}{36 x}$ & 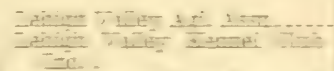 & $-1+2$ & 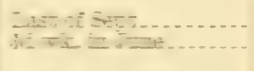 & 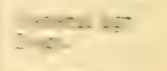 \\
\hline 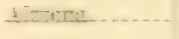 & 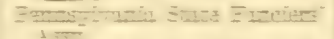 & Yhist: & ax... & $9=-$ \\
\hline sativer & 1 & $=$ & 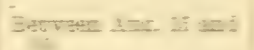 & 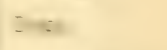 \\
\hline $220 \sin$. & 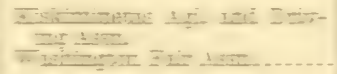 & 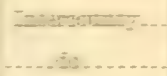 & 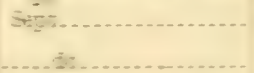 & $\begin{array}{l}\text { Exweri ar. } \\
\text { Fr. }\end{array}$ \\
\hline 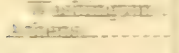 & 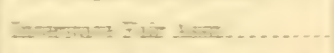 & In-xistam? & 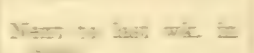 & Ens. \\
\hline$\frac{1-a i}{2} \equiv$ & 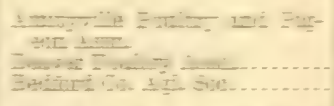 & Inosmon & wetar at & $\begin{array}{l}\text { Des. } \\
\text { Sunterio agr. }\end{array}$ \\
\hline 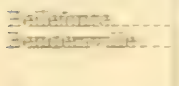 & 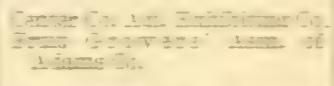 & Hosic & 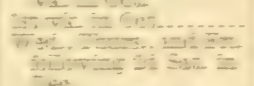 & Erricuinase \\
\hline Baricentum & 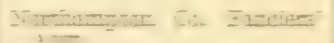 & Sistersi & 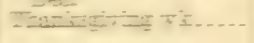 & $E \pi \div$ \\
\hline 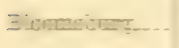 & Enimir & 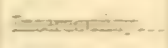 & $2 \mathrm{vi}=\mathrm{set}$ & Carem: arr. \\
\hline 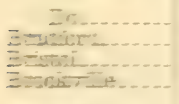 & 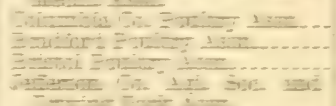 & Vistion: & $\pi \pm$ ofted 2. & 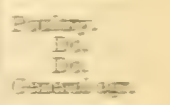 \\
\hline$z=110$ & 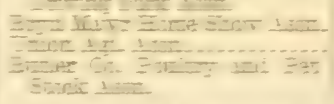 & Gor & 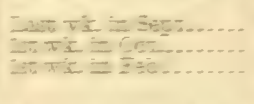 & Fureriar. \\
\hline
\end{tabular}

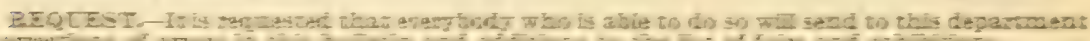

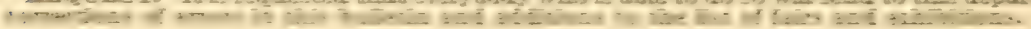




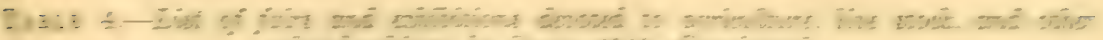

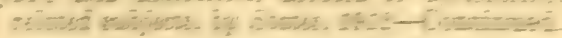

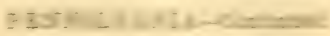

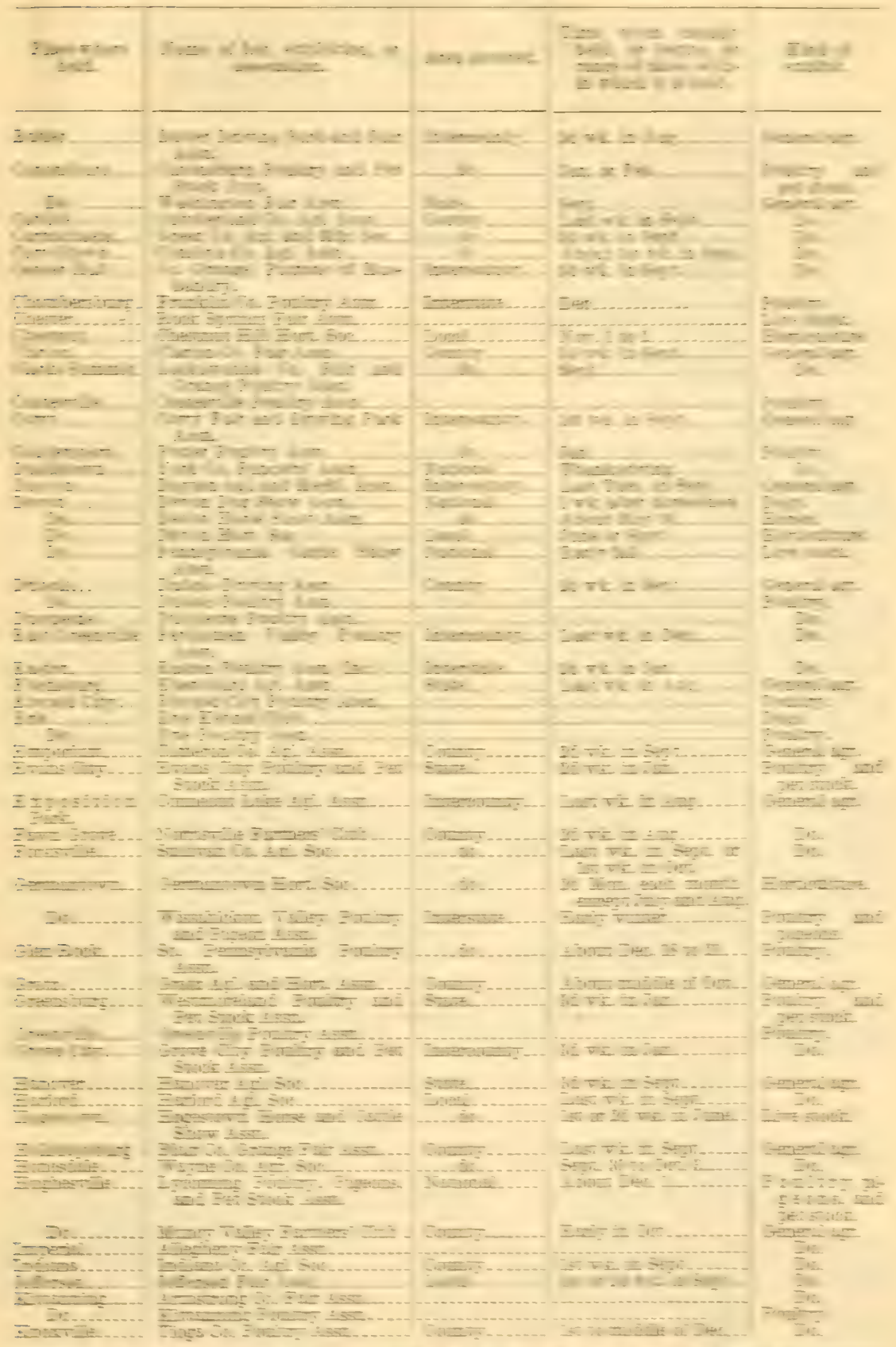

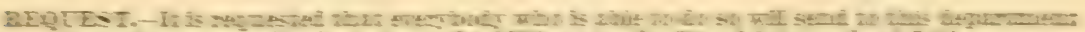

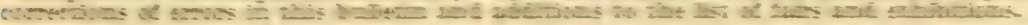


TABLE 4.-List of fairs and exhibitions devoted to agriculture, live stock, and other related subjects, by States, 1912-Continued.

PENNSYLVANIA-Continued

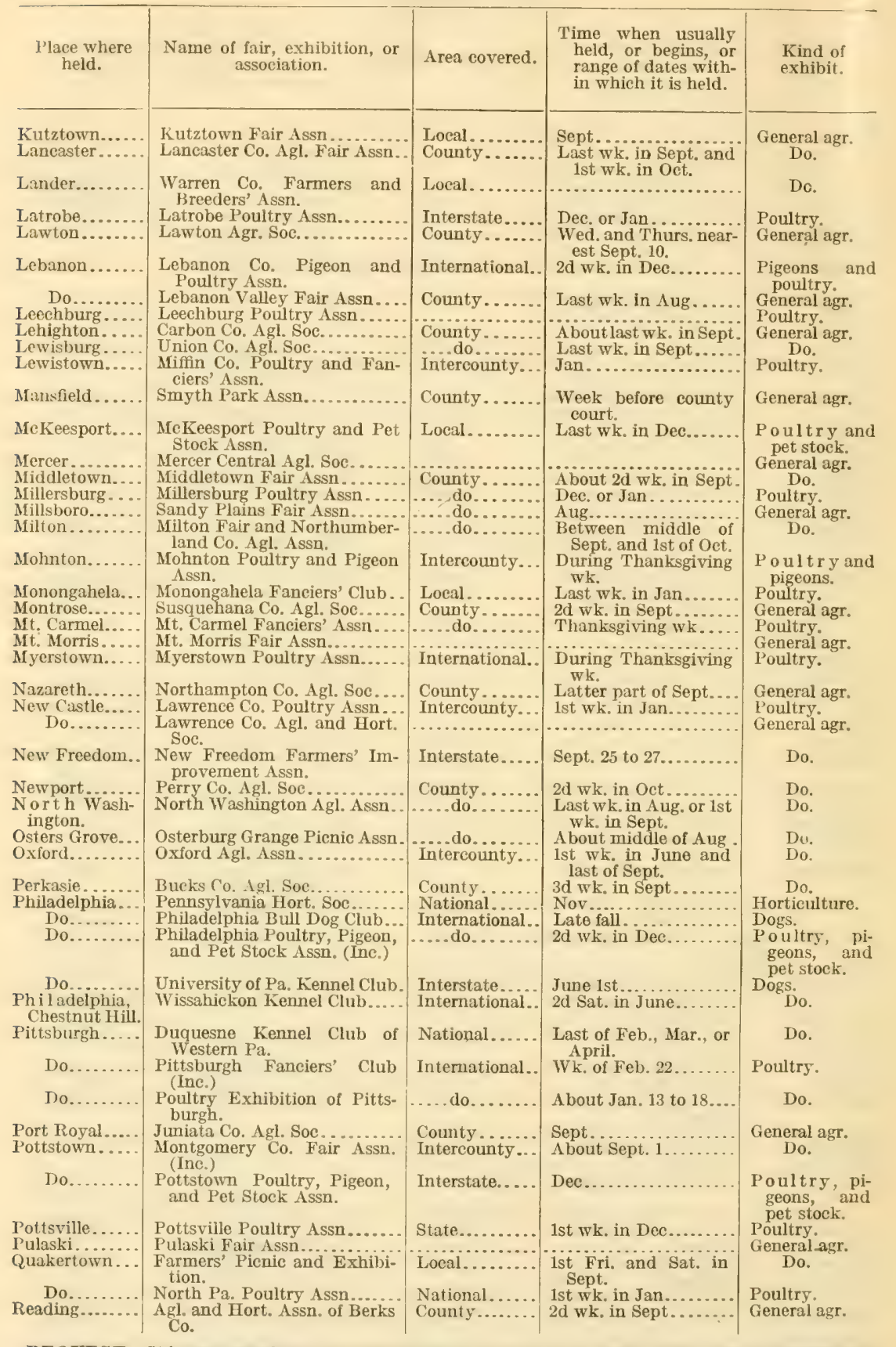

REQUEST.-It is requested that everybody who is able to do so will send to this department corrections of errors in this bulletin and additions to the list of fairs and exhibitions. 
TABLE 4.-List of fairs and exhibitions devoted to agriculture, live stock, and other related subjects, by States, 1912-Continued.

PENNSYLVANIA-Continued.

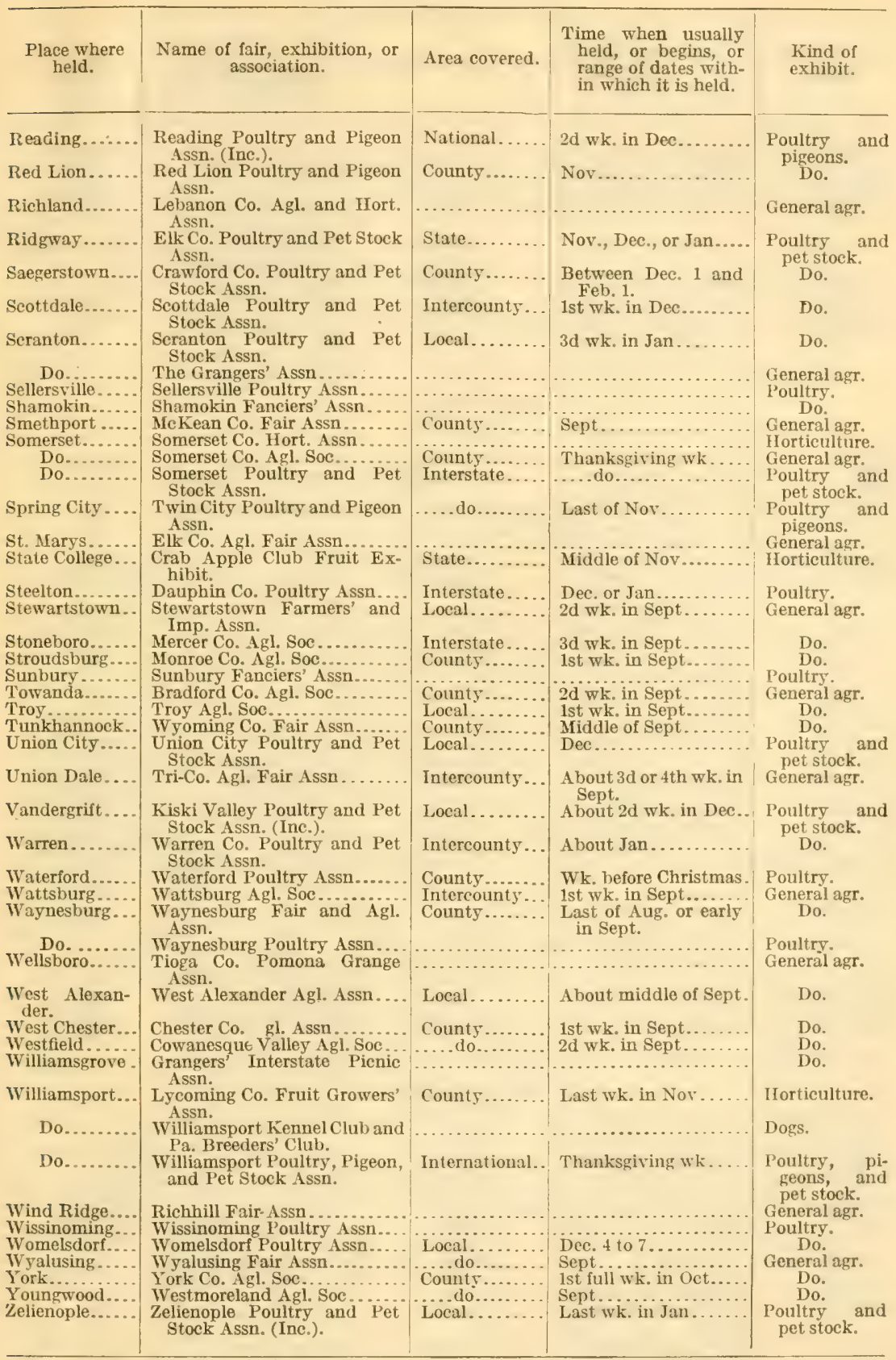

REQUEST.-It is requested that everybody who is able to do so will send to this department corrections of errors in this bulletin and additions to the list of fairs and exhibitions. 
TABLE 4.-List of fairs and exhibitions devoted to agriculture, live stock, and other related subjects, by States, 1912-Continued.

RHODE ISLAND.

\begin{tabular}{|c|c|c|c|c|}
\hline $\begin{array}{l}\text { Place where } \\
\text { held. }\end{array}$ & $\begin{array}{c}\text { Name of fair, exhibition, or } \\
\text { association. }\end{array}$ & Area covered. & $\begin{array}{l}\text { Time when usually } \\
\text { held, or begins, or } \\
\text { range of dates with- } \\
\text { in which it is held. }\end{array}$ & $\begin{array}{l}\text { Kind of } \\
\text { exhibit. }\end{array}$ \\
\hline $\begin{array}{l}\text { Bristol Ferry... } \\
\text { Bristol........ } \\
\text { Greystone..... } \\
\text { Hillsgrove..... } \\
\text { Newport....... } \\
\text { Do......... } \\
\text { Do........ } \\
\text { TVest Kingston. } \\
\text { Westerly....... } \\
\text { Wickford....... }\end{array}$ & $\begin{array}{l}\text { Newport Co. Agl. Soc......... } \\
\text { Bristol Co. Poultry Assn..... } \\
\text { Greystone Poultry Assn...... } \\
\text { Rhode Island State Fair...... } \\
\text { Newport Horse Show Assn... } \\
\text { Newport Hort. Soc........... } \\
\text { Rhode Island Kennel Club.... } \\
\text { Washington Co. Agl. Soc...... } \\
\text { South Co. Poultry Assn...... } \\
\text { North Kings Town Poultry } \\
\text { Assn. }\end{array}$ & 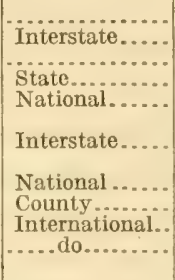 & 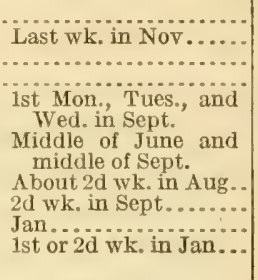 & $\begin{array}{l}\text { General agr. } \\
\text { Poultry. } \\
\text { Do. } \\
\text { General agr. } \\
\text { Horses. } \\
\text { Horticulture. } \\
\text { Dogs. } \\
\text { General agr. } \\
\text { Poultry. } \\
\text { Do. }\end{array}$ \\
\hline
\end{tabular}

SOUTH CAROLINA.

\begin{tabular}{|c|c|c|c|c|}
\hline Abbeville. & Abbeville Co. Fair Assn........ & National. & $3 \mathrm{~d} w \mathrm{k}$, in Oct.. & General agr. \\
\hline Aiken...... & Aiken Co. Fair Assn.......... & Intercounty... & A bout Oct. 22 to $24 \ldots$ & Do. \\
\hline Anderson. & Anderson Co. Fair...... & & & Do. \\
\hline Bamwell.. & Barnwell Co. Fair Assn. (Inc.). & County. & Oct. 20 to Nov, $15 \ldots$. & Do. \\
\hline Batesburg...... & Tri-co. Fair Assn. of Batesburg. & & $\ldots \ldots \ldots \ldots \ldots$ & Do. \\
\hline Beech Island... & Beech Island Agl. Club....... & & & Do. \\
\hline Bennettsville.. & Marlboro Poultry Assn........ & County.. & Dec. & Poultry. \\
\hline Camden........ & Camden Polo Club............ & Intercounty... & $\begin{array}{l}\text { Last Wed. and Thurs. } \\
\text { of Mareh. }\end{array}$ & Horses. \\
\hline $\begin{array}{l}\text { Do. } \\
\text { Do. }\end{array}$ & Camden Poultry Assn... & & & ltry. \\
\hline $\begin{array}{l}\text { Do...... } \\
\text { Charleston. }\end{array}$ & Kershaw Co. Fair Assn.... & County & Nov. 8 to 10 & General agr. \\
\hline Columbia. . & $\begin{array}{l}\text { Charleston Co. Fair Assn..... } \\
\text { State Agl. and Mechl. Soc. } \\
\text { (State Fair). }\end{array}$ & Interstate..... & Last wk. in Oct. & $\begin{array}{l}\text { Do. } \\
\text { Do. }\end{array}$ \\
\hline Do. & South Atlantic Corn Expo.... & & & Corm. \\
\hline Edgefield. & Edgefield Co. Fair Assn... & & & General agr. \\
\hline Ellentown. & Ellentown Agl. Club.... & & & Do. \\
\hline Florence... & Florence Co. Fair Assn........ & & & Do. \\
\hline Greenville...... & Greenville Horse Show Assn.. & ate..... & $3 \mathrm{~d}$ wk. in May. & Horses, \\
\hline Greenwood..... & Greenwood Fair Assn......... & County...... & Last wk. in Oet & General agr. \\
\hline Laurens.... . . . . . & Laurens Co. Fair Assn ......... & ..... do......... & 3d Fri. in Oct. & Do. \\
\hline $\begin{array}{l}\text { lexington ...... } \\
\text { Madden. }\end{array}$ & $\begin{array}{l}\text { Lexington Co. Fair Assn ....... } \\
\text { Laurens Co. Live Stock Assn. }\end{array}$ & do & Last wk. in oct & $\begin{array}{l}\text { Do. } \\
\text { Live stock. }\end{array}$ \\
\hline North Augusta. & Schultz Hill Agl. Club....... & & & General agr. \\
\hline Orangeburg.... & Orangeburg Co. Fair Assn... & Intercounty... & Between Nov. 1 and 18. & Do. \\
\hline Parksville...... & $\begin{array}{l}\text { West Side Fair and Stock } \\
\text { Show Assn. }\end{array}$ & .... do....... & ................ & \\
\hline Simpsonville. & $\begin{array}{l}\text { Fairview Stock, Agl., and } \\
\text { Mfechl. Assn. }\end{array}$ & & & \\
\hline Spartanburg. . & Spartanburg Co. Fair Assn. . & & & Do. \\
\hline Do.. & Spartanburg Poultry Assn... & Interstate. & Dec. & Poultry. \\
\hline Union... & Union Co. Fair Assn......... & County.... & A bout Oct. 16 to $18 \ldots$ & General agr. \\
\hline Walterboro...... & Colleton Co. Fair Assn .... . & ..... do.. & $2 \mathrm{~d}$ wk. in Nov. & Do. \\
\hline Winnsboro..... & Fairfield Co. Fair Assn.... & ....do.. & From Oct. 15 to Nov. 1. & Do. \\
\hline Woodruff. & Woodruff Agl. Soc.. & Local & $2 d$ wk. in Oct. . & Do. \\
\hline
\end{tabular}

SOUTH DAKOTA.

\begin{tabular}{|c|c|c|c|c|}
\hline Alexandria..... & Hanson Co. Fair Assn. & County... & Sept. 19 to $24 .$. & General agr. \\
\hline Armour....... & Douglas Co. Fair Assn........ & .... do... & Aug. 28 to $30 \ldots$. & Do. \\
\hline Belle Fourche. & Black Hills Poultry Assn.... & Interstate.... & Jan ............... & Poultry. \\
\hline Do........... & Butte Co. Fair Assn............. & County....... & Sept...... & General agr. \\
\hline Brookings...... & South Dakota State Hort. Soc. & & & Horticulture. \\
\hline Clark........... & Clark Co. Agl. Fair Assn...... & County... & $\begin{array}{l}\text { Between Sept. } 1 \text { and } \\
10 .\end{array}$ & General agr. \\
\hline Clear Lake & Fair Assn ... & Intercounty... & $\begin{array}{l}\text { Last } 4 \text { days of last wk. } \\
\text { in Sept. }\end{array}$ & Do. \\
\hline Highmore...... & Hyde Co. Fair Assn........... & & & Do. \\
\hline Huron......... & $\begin{array}{l}\text { South Dakota State Board of } \\
\text { Agr. }\end{array}$ & State. & $2 d$ wk. in Sept......... & Do. \\
\hline $\begin{array}{l}\text { Kadoka... } \\
\text { Kimball.. }\end{array}$ & $\begin{array}{l}\text { Stanley Co. Fair Assn..... } \\
\text { Brule Co. Fair Assn...... }\end{array}$ & $\begin{array}{l}\text { County } \\
\ldots \text { do. }\end{array}$ & $\begin{array}{l}\text { 3d wk. in Sept... } \\
\text { Sept.............. }\end{array}$ & $\begin{array}{l}\text { Do. } \\
\text { Do. }\end{array}$ \\
\hline
\end{tabular}

IEQUEST.-It is requested that everybody who is able to do so will send to this department corrections of errors in this bulletin and additions to the list of fairs and exhibitions. 
TABLE 4.-List of fairs and exhibitions devoted to arriculture, live stock, and other related subjects, by States, 1912-Continued.

SOUTH DAKOTA-Continued.

\begin{tabular}{|c|c|c|c|c|}
\hline $\begin{array}{l}\text { Place where } \\
\text { held. }\end{array}$ & $\begin{array}{c}\text { Name of fair, exhibition, or } \\
\text { association. }\end{array}$ & Area covered. & $\begin{array}{l}\text { Time when usually } \\
\text { held, or begins, or } \\
\text { range of dates with- } \\
\text { in which it is held. }\end{array}$ & $\begin{array}{l}\text { Kind of } \\
\text { exhibit. }\end{array}$ \\
\hline 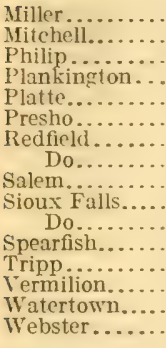 & 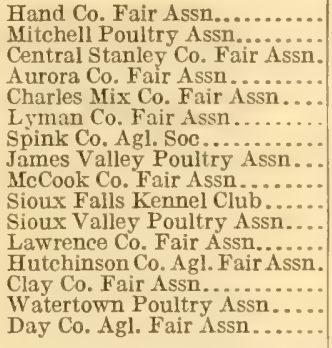 & 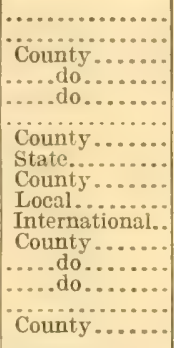 & 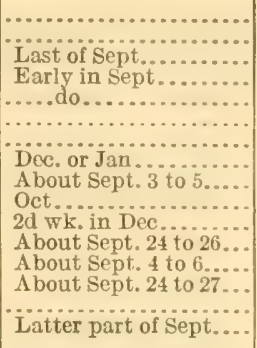 & $\begin{array}{l}\text { General agr. } \\
\text { Poultry. } \\
\text { General agr. } \\
\text { Do. } \\
\text { Do. } \\
\text { Do. } \\
\text { Do. } \\
\text { Poultry. } \\
\text { General agr. } \\
\text { Dogs. } \\
\text { Poultry. } \\
\text { General agr. } \\
\text { Do. } \\
\text { Do. } \\
\text { Poultry. } \\
\text { General agr. }\end{array}$ \\
\hline
\end{tabular}

TENNESSEE.

\begin{tabular}{|c|c|c|c|c|}
\hline Alexandria..... & $\begin{array}{l}\text { Dekalb Co. Agl. and Mechl. } \\
\text { Assn. }\end{array}$ & Intercounty... & 1st wk. in Sept........ & General agr. \\
\hline Bristol. & Bristol Poultry Assn . . . . . . . . & & & Poultry. \\
\hline Brownville..... & Haywood Co. Fair Assn. & County. & 1st or $2 \mathrm{~d}$ wk in Oct. & General agr. \\
\hline Celina.......... & Clay Co. Fair Assn...... & State... & $\begin{array}{l}\text { 1st Thurs., Fri., and } \\
\text { Sat, in Oct. }\end{array}$ & Do. \\
\hline Chattanooga... & Chattanooga Poultry Assn. & Local. & Dec, or Jan............ & Poultry. \\
\hline Do Clarkswille....... & $\begin{array}{l}\text { Hamilton Co. Fair Issn........ } \\
\text { Montgomery Co. Fair Assn... }\end{array}$ & & …........ & $\begin{array}{c}\text { General agr. } \\
\text { Do. }\end{array}$ \\
\hline Clarkswine...... & Bradley Co. Fair Assn........ & County... & A bout Oct. 15 to $18 . .$. & Do. \\
\hline Coal Creek..... & $\begin{array}{l}\text { Anderson and Campbell Cos. } \\
\text { Stock and Fair Assn. }\end{array}$ & ..... do.......... & $\begin{array}{l}\text { From last of Aug. to } \\
\text { Sept. } 15 .\end{array}$ & Do. \\
\hline $\mathrm{Col}$ & Tennessee Fair Assn .......... & .00 & Sept................. & Do. \\
\hline Cor & Concord Fair Assn.... & Interstate... & Aug. 15 to Sep & Do. \\
\hline keville..... & Putnam Co. Fair Assn.. & & & Do. \\
\hline dge.... & Morgan Co. Fair Assn... & County... & Sept. & Do. \\
\hline & kley Co. Fair Assn. & .... do.. & Sept. 25 to $\mathrm{O}$ & Do. \\
\hline D & Dyer Co. Fair Assn.. & Intercounty... & or Oct. & Do. \\
\hline tteville.... & Lincoln Co. Fair Assn.... & County......... & t Aug. & Do. \\
\hline atin $\ldots . . . .$. & Sumner Co. Fair and Sale Assn. & Intercounty... & 3d or 4th wk. in Aug... & Do. \\
\hline ille..... & Greene Co. Fair Assn........... & County........ & Sept................... & $\begin{array}{l}\text { Do. } \\
\text { Poultry. }\end{array}$ \\
\hline lle...... & Hartsville Poultry Assn........ & & & Do. \\
\hline boldt..... & Humboldt Tri-Co. Fair Assn. . & Int & Las & General agr. \\
\hline tingdon... & Carroll Co. Fair Assn ............ & County... & at Oet. 1 & Do. \\
\hline Jackson ...... & $\begin{array}{l}\text { West Tennessee Agl. and } \\
\text { Mechl. Fair Assu. }\end{array}$ & National. & $\begin{array}{l}\text { Last wk. in Sept. or } \\
\text { 1st wk. in Oct. }\end{array}$ & Do, \\
\hline Do & West Tenneseee Kennel Club.. & & April or May. & Dogs. \\
\hline D & West Tennessee Poultry Assn.. & Intercour & 1 st or $2 \mathrm{~d} \mathrm{wh}$ & Poultry. \\
\hline a City... & on City Poultry Assn .... & & & \\
\hline & $\begin{array}{l}\text { Roane Co. Fair Assn......... } \\
\text { Appalachian Dog Show Expo. }\end{array}$ & $\mathrm{Co}$ & Se & $\begin{array}{l}\text { General agr. } \\
\text { Dogs. }\end{array}$ \\
\hline & East Tennessee Poultry Assn... & Intercounty... & $3 \mathrm{~d}$ wk. in Jas & Poultry. \\
\hline Lafaye & $\begin{array}{l}\text { Macon Co. Agl., Mechl. and } \\
\text { Live Stock Ass'n. }\end{array}$ & & $\ldots$ & General agr. \\
\hline Le & Marshall Co. Fair Assn... & Inter & $\mathrm{Au}$ & $\Gamma_{2}$ \\
\hline M & Weakley Co. Poultry Assr & $\mathrm{Cot}$ & $\begin{array}{l}\text { Between Dec. } 15 \text { and } \\
\text { Jan. } 15 \text {. }\end{array}$ & y. \\
\hline MIempl & $\mathrm{Tr}$ & In & 4th wk. in Sept. & General agr. \\
\hline & Tri-State Poultry Assn.. & lational.. & Iast wk. in Sept. & 0 \\
\hline Morrist & Hamblen Co. Poultry Assn.... & Y & Dec. 1 to $15 . . . . .$. & Poultry. \\
\hline Do & wn Fair Assn.... & Int & Sept. & General agr. \\
\hline sboro. & Rutherford Co. Fair Assn. & & Aug. or Sept... & $\begin{array}{l}\text { Do } \\
\text { Do }\end{array}$ \\
\hline & $\begin{array}{l}\text { Tennessee State Fair Assn ..... } \\
\text { Tennessee State Hort. Soc.... }\end{array}$ & $\begin{array}{l}\text { National. } \\
\text { State..... }\end{array}$ & $\begin{array}{l}3 d \text { wk. in Sept. } \\
3 d \text { wk. in } J_{\text {an }} .\end{array}$ & Horticulture. \\
\hline $180 \mathrm{n}$ & Appalachian Fair $\Lambda$ ssn & county. & Middle of Sept. & General agr. \\
\hline Paris. & Henry Co. Fair Assn.. & County... & Last wk. in Sept. or & \\
\hline$P$ & Giles Co. Farmers' Assn ....... & & Sept. 10 to 2 & $\mathrm{D}$ \\
\hline & $\begin{array}{l}\text { Smith Co. Agl. and Mechl. } \\
\text { Assn. }\end{array}$ & & Sept.. & \\
\hline
\end{tabular}

REQUEST.-It is requested that everybody who is able to do so will send to this department corrections of errors in this bulletin and additions to the list of fairs and exhibitions. 
TABLE 4.-List of fairs and exhibitions devoted to agriculture, live stock, and other related subjects, by States, 1912-Continued.

TENNESSEE-Continued.

\begin{tabular}{|c|c|c|c|c|}
\hline $\begin{array}{l}\text { Place where } \\
\text { held. }\end{array}$ & $\begin{array}{c}\text { Name of fair, exhibition, or } \\
\text { association. }\end{array}$ & Area covered. & $\begin{array}{l}\text { Time when usually } \\
\text { held, or begins, or } \\
\text { range of dates with- } \\
\text { in which it is held. }\end{array}$ & $\begin{array}{l}\text { Kind of } \\
\text { exhibit. }\end{array}$ \\
\hline $\begin{array}{l}\text { Selmer........ } \\
\text { Shelbyville.... } \\
\text { South P itts - } \\
\text { burg. } \\
\text { Trenton........ } \\
\text { Tullahoma..... } \\
\text { Union City ..... } \\
\text { Waverly...... } \\
\text { Winchester.... }\end{array}$ & $\begin{array}{l}\text { McNairy Co. Fair Assn........ } \\
\text { Bedford Co. Fair Assn ........ } \\
\text { Sequahee Valley Fair Assn... } \\
\text { Gilson Co. Fair Assn .......... } \\
\text { Tullahoma Fair Assn ......... } \\
\text { West Tennessee Fair Assn ... } \\
\text { Humphreys Co. Fair Assn.... } \\
\text { Franklin Co. Fair Assn ...... }\end{array}$ & 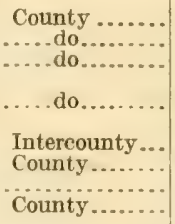 & 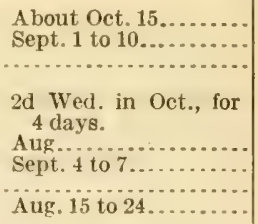 & $\begin{array}{l}\text { General agr. } \\
\text { Do. } \\
\text { Do. } \\
\text { Do. } \\
\text { Do. } \\
\text { Do. } \\
\text { Do. } \\
\text { Do. }\end{array}$ \\
\hline
\end{tabular}

TEXAS.

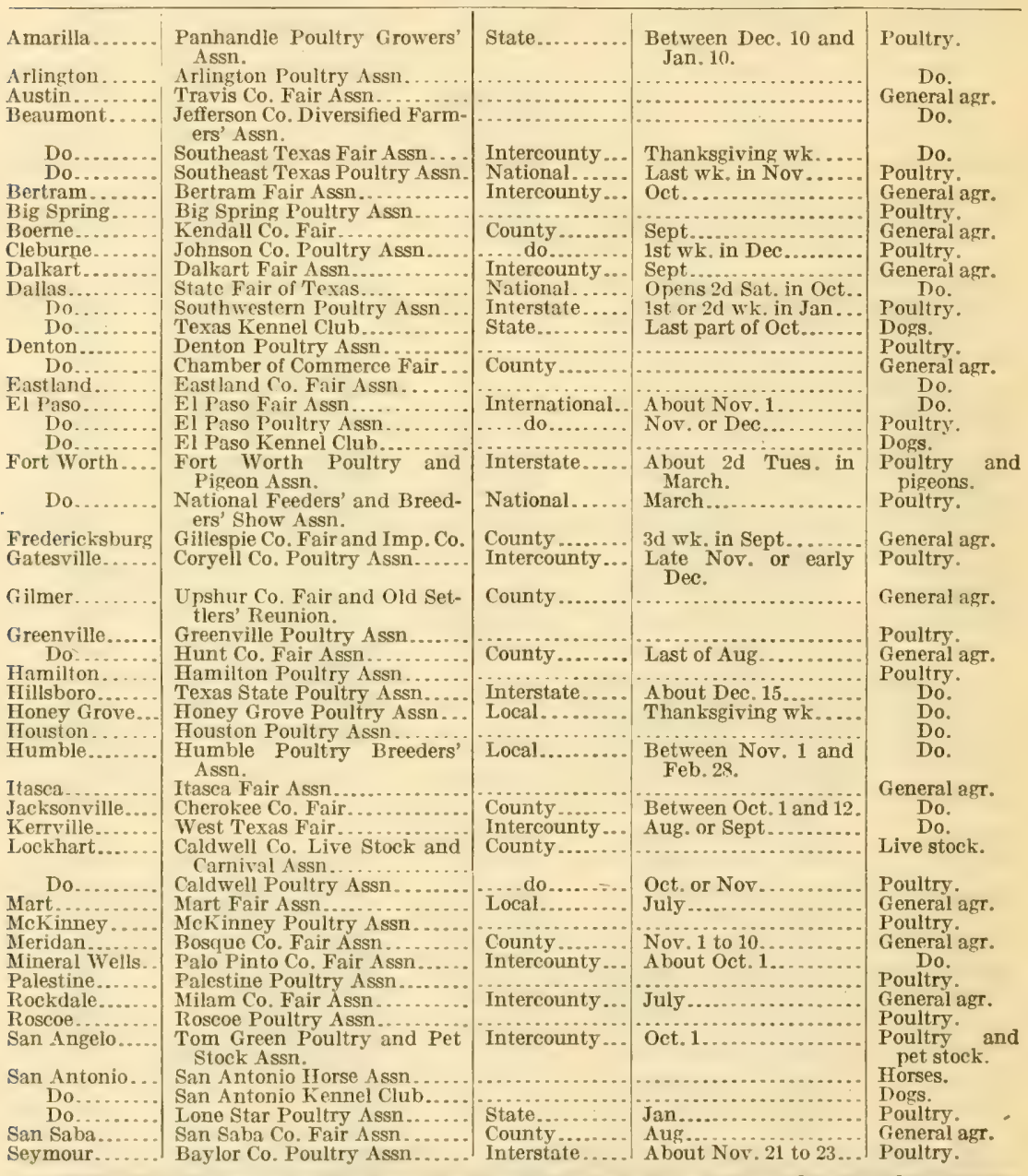

REQUEST.-It is requested that everybody who is able to do so will send to this department corrections of errors in this bulletin and additions to the list of fairs and exhibitions. 
TABLE 4.-List of fairs and exhibitions devoted to agriculture, live stock, and other related subjects, by States, 1912-Continued.

TEXAS-Continued.

\begin{tabular}{|c|c|c|c|c|}
\hline $\begin{array}{l}\text { Place where } \\
\text { held. }\end{array}$ & $\begin{array}{c}\text { Name of fair, exhibition, or } \\
\text { association. }\end{array}$ & Area covered. & $\begin{array}{l}\text { Time when usually } \\
\text { held, or begins, or } \\
\text { range of dates with- } \\
\text { in which it is held. }\end{array}$ & $\begin{array}{l}\text { Kind of } \\
\text { exhibit. }\end{array}$ \\
\hline Sherman. & Sherman Poultry Assn... & & & Poul \\
\hline Taylor... & Taylor Fair Assn........ & Local... & July ... & General agr. \\
\hline & Taylor Poultry Assn..... & State... & Dec.... & Poultry. \\
\hline Texa & Texarkana Poultry Assn... & & & Do. \\
\hline Victoria.. & $\begin{array}{l}\text { Gulf Coast Pouitry and Pet } \\
\text { Stock Assn. }\end{array}$ & Intercounty. & Between Dec. 6 and 12 . & $\begin{array}{l}\text { Poultry and } \\
\text { pet stock. }\end{array}$ \\
\hline Wace & Waco Poultry Assn ......... . & & & Poultry. \\
\hline Weatherfor & Weatherford Poultry Issn. & & - & Do. \\
\hline
\end{tabular}

UTAH.

\begin{tabular}{|c|c|c|c|c|}
\hline 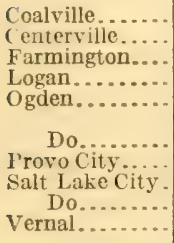 & 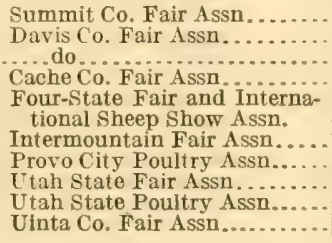 & 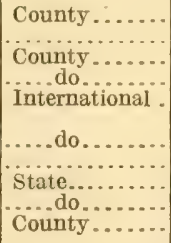 & $\begin{array}{l}\text { Last wk. in Sept...... } \\
\text { Irregular; Sept. or Oct. } \\
\text { Last part of Sept...... } \\
\text { About Sept. } 20 . . . . \\
\text { Last wk. in Sept....... } \\
\text { 1st wk. in Oct.......... } \\
2 \text { d or } 3 \text { d wk. in Jan... } \\
\text { Sept. } 3 \text { to } 10 . . . . . . . . .\end{array}$ & $\begin{array}{l}\text { General agr. } \\
\text { Do. } \\
\text { Do. } \\
\text { Do. } \\
\text { General agr. } \\
\text { and sheep. } \\
\text { General agr. } \\
\text { Poultry. } \\
\text { General agr. } \\
\text { Poultry. } \\
\text { General agr. }\end{array}$ \\
\hline
\end{tabular}

VERMONT.

\begin{tabular}{|c|c|c|c|c|}
\hline Arlington & Battenkill Fair Assn. & & & General agr. \\
\hline $\begin{array}{l}\text { Barre or Mont- } \\
\text { pelier. }\end{array}$ & Vermont Poultry Assn... & National..... & Last wk. in Dec........ & Poultry. \\
\hline Barton.......... & Orleans Co. Fair Assn. & County. & About Aug. 20 to 22 . & General agr. \\
\hline Bellows Falls.. & Bellows Falls Poultry Assn... & & & Poultry. \\
\hline Bradford.. & $\begin{array}{l}\text { Bradford Agl. and Trotting } \\
\text { Assn. }\end{array}$ & County. & Last wk. in Aug...... & General agr. \\
\hline Brattleboro.... & Valley Fair Assn....... & National. & Last wk. in Sep & Do. \\
\hline Bristol........ & Addison Co. Poultry Assn..... & County... & Jan............. & Poultry. \\
\hline Canaan.. & Essex Co. Fair Assn.......... & & & General agr. \\
\hline E. Hardwick... & Caledonia Grange Fair Assn... & Local.. & 3d Sat. in Sept. & Do. \\
\hline Fair Haven... & Western Vermont Agl. Soc.... & ..... do. & $2 \mathrm{~d}$ wk. in Sept. & Do \\
\hline $\begin{array}{l}\text { Manchester } \\
\text { Center. }\end{array}$ & Battenkill Valley Indusl. Soc. & County. & Sept. 15 to 20 . & Do. \\
\hline Middlebury.... & Addison Co. Agl. Soc. & Intercounty... & Last wk. in Aus & De \\
\hline Do.. & Vermont State Hort. Soc. & State.......... & $\begin{array}{l}\text { Wk. before Thanks- } \\
\text { giving. }\end{array}$ & Horticulture. \\
\hline Morrisville & $\begin{array}{l}\text { Lamoille Valley Fair Grounds } \\
\text { Co. }\end{array}$ & County. & $\begin{array}{l}\text { Last Tues., Wed., } \\
\text { Thurs, in Aug. }\end{array}$ & General agr. \\
\hline Northfield & Dog River Valley Fair Assn.. & Intere & Sept. 10 to $20 \ldots . . .$. & 100. \\
\hline North Pomfret. & Vermont Dairyman's Assn. & State. & & Dairy prod- \\
\hline Rutland & Rutlanc & National & Early in Sep & General agr. \\
\hline Sheldor & $\begin{array}{l}\text { Rutland Horse Show Assn } \\
\text { Franklin Co. Fair Assn }\end{array}$ & Count & 1st Wed Thy & IIorses. \\
\hline & & & in Sept. & \\
\hline Springfiel & Springfield & . do & 1st to middle of Sept.. & D \\
\hline & $\begin{array}{l}\text { Vermont State Poultry Assn. } \\
\text { (Inc.). }\end{array}$ & International. & 3d wk. in Jan. ........ & Poultry. \\
\hline St. Johnsbury.. & Caledonia Fairgrounds Co.. & County & $2 d$ & General agr. \\
\hline Tunbridge. & Union Agl. Soc. & Local. & Last of Sept. & Do. \\
\hline $\begin{array}{l}\text { White River } \\
\text { Junction. }\end{array}$ & Vermont State Fair As & State.. & $3 \mathrm{~d}$ wk. in Sept. & Do \\
\hline Woodstock. & Windsor Co. Agl. Soc & County. & Sept. 10 to 15 & Do. \\
\hline
\end{tabular}

\section{VIRGINIA.}

\begin{tabular}{|c|c|c|c|c|}
\hline Abingdon. & Abingdon Poultry Assn. . & & & Poultry. \\
\hline Berryville. & $\begin{array}{l}\text { Clarke Co. Horse and Colt } \\
\text { Show Assn. }\end{array}$ & Interstate. & $\begin{array}{l}1 \text { wk. later than Aug. } \\
15 .\end{array}$ & Horses. \\
\hline Charlottesville. & Albemarle Agl. Fair..... & County & 1st wk. in Nov ....... & General ag \\
\hline Do......... & A tbemarle Horse Show Assn . & National...... & About Aug. 1......... & Horses. \\
\hline & Albemarle Poultry $\Lambda$ ssn (Inc.) & International & Nov $\ldots . . .$. & Poultry. \\
\hline
\end{tabular}

REQUEST.-It is requested that everybody who is able to do so will send to this department corrections of errors in this bulletin and additions to the list of fairs and exhibitions. 
TABLE 4.-List of fairs and exhibitions devoted to agriculture, live stock, and other related subjects, by States, 1912 -Continued.

VIRGINIA-Continued.

\begin{tabular}{|c|c|c|c|c|}
\hline $\begin{array}{l}\text { 1'lace where } \\
\text { held. }\end{array}$ & $\begin{array}{l}\text { Name of fair, exhibition, or } \\
\text { association. }\end{array}$ & Area covered. & $\begin{array}{l}\text { Time when usually } \\
\text { held, or begins, or } \\
\text { range of dates with- } \\
\text { in which it is held. }\end{array}$ & $\begin{array}{l}\text { Kind of } \\
\text { exhibit. }\end{array}$ \\
\hline Charlottesville. & $\begin{array}{l}\text { Charlottesville } \mathrm{Agl} \text {. and In- } \\
\text { dustrial Fair Assn. }\end{array}$ & State.... & 1st wk. in Oet... & General agr. \\
\hline Do. . & Colored Horse Show and Fair & & & Horses. \\
\hline Culpeper. & $\begin{array}{l}\text { Assn. } \\
\text { Culpeper Horse show, Fair, } \\
\text { and Racing Assn. }\end{array}$ & Local & July. & Do. \\
\hline ant & Danville Fa & Intercou & Middle of Oc & General agr. \\
\hline & $A g l$ & & Last of Oct. & Do. \\
\hline alls Cht & $\begin{array}{l}\text { Fairfax Co. Fair Assn. (Inc.). } \\
\text { Falls Church Poultry Assn... }\end{array}$ & County & Oct........ & $\begin{array}{l}\text { Do. } \\
\text { Poultry. }\end{array}$ \\
\hline Farmvi & $\begin{array}{l}\text { Buffalo Riding and Driving } \\
\text { Assn. }\end{array}$ & Intercounty. & Last of Oct. & Horses. \\
\hline Fort Myer & $\begin{array}{l}\text { Fort iyer Military Horse } \\
\text { Show. }\end{array}$ & Loca & Middle of $A_{1}$ & Do. \\
\hline $\begin{array}{l}\text { Front Royal... } \\
\text { Do.......... }\end{array}$ & $\begin{array}{l}\text { Front Royal Horse Show Assn. } \\
\text { Front Royal Poultry Show }\end{array}$ & Interstate.... & $\begin{array}{l}\text { Aug. } \\
\text { Nov }\end{array}$ & $\begin{array}{l}\text { Do. } \\
\text { Poultry. }\end{array}$ \\
\hline Gala: & $\begin{array}{l}\text { Assn } \\
\text { Galax Fair Assn .................... }\end{array}$ & Intel & Last & Gener \\
\hline $\begin{array}{l}\text { Grafton (Up- } \\
\text { perville). }\end{array}$ & $\begin{array}{l}\text { Upperville Colt and Horse } \\
\text { Club. }\end{array}$ & Loca & June & Horse \\
\hline $\begin{array}{l}\text { Jones } \\
\text { Kelle }\end{array}$ & $\begin{array}{l}\text { Fair Assn.............. } \\
\text { Shore Agl, Assn ...... }\end{array}$ & $\begin{array}{l}\text { Coun } \\
\text { Inter }\end{array}$ & $\begin{array}{l}\text { Sept. } \\
\text { Last } v\end{array}$ & $\begin{array}{l}\text { General agr. } \\
\text { Do. }\end{array}$ \\
\hline Kes & $\begin{array}{l}\text { Keswick Hunt Club and } \\
\text { Horse Show Assn. }\end{array}$ & Loc & Abo & Horses. \\
\hline 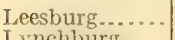 & w Assn.... & $\ldots d t$ & June 1 & $\mathrm{D}$ \\
\hline $\begin{array}{ll}y \\
1\end{array}$ & y Assn A..... & & & $\begin{array}{l}\text { Poultry. } \\
\text { General agr. }\end{array}$ \\
\hline Tapi & ona & & & Do. \\
\hline & & Cour & & Do. \\
\hline & $\mathrm{NCo}$ & Int & La & IIors \\
\hline . & $\begin{array}{l}\text { Norfolk Hort. and Pomolog- } \\
\text { ical Soc. }\end{array}$ & & & ulture. \\
\hline & $\begin{array}{l}\text { Norfolk-Portsmouth Kennel } \\
\text { Assn. (Inc.). }\end{array}$ & Inters & Irregular...... & Dogs. \\
\hline Do & $\begin{array}{l}\text { Tidewater Poultry Assn. } \\
\text { (Inc.). }\end{array}$ & International & Dec. or Jal & Poultry. \\
\hline nar & & & & Gene \\
\hline$\underset{D}{\text { Orang }}$ & 's $\operatorname{ssn} \ldots \ldots \ldots . . . . . .$. & $\begin{array}{l}\text { Int } \\
\text { Cou }\end{array}$ & $\begin{array}{l}\text { Let ast of July or early } \\
\text { in Aug. }\end{array}$ & $\begin{array}{l}\text { Do. } \\
\text { Horses. }\end{array}$ \\
\hline $\begin{array}{l}\text { Painte } \\
\text { Petersk }\end{array}$ & Agl. and & Inter & About $2 d$ wk. in Oet. & $\begin{array}{l}\text { General agr. } \\
\text { Do. }\end{array}$ \\
\hline Radfor & . Agl. and Live & & $\mathrm{Se}$ & Do \\
\hline Ric & & & & \\
\hline & $\begin{array}{l}\text { Roanoke Industrial and } A \mathrm{gl} \text {. } \\
\text { Assn. }\end{array}$ & & $\begin{array}{l}\text { Abont last wk. in } \\
\text { Sept. }\end{array}$ & \\
\hline $\begin{array}{l}\text { Do. } \\
\text { Suffolk. }\end{array}$ & $\begin{array}{l}\text { Roanoke Poultry Assn. (Inc.). } \\
\text { Nansemond Co. School Fair } \\
\text { Assn. }\end{array}$ & $\begin{array}{l}\text { International } \\
\text { Intercounty.. }\end{array}$ & $\begin{array}{l}\text { About Jan. } 7 \text { to } 11 \ldots . . \\
\text { Early in Oct.......... }\end{array}$ & $\begin{array}{l}\text { Poultry. } \\
\text { General agr. }\end{array}$ \\
\hline Tas & Agl Fair As & $\mathrm{Na}$ & $3 \mathrm{~d} o$ & \\
\hline & & Cou & lst $\mathrm{y}$ & $\begin{array}{l}\mathrm{D} \\
\mathrm{D}\end{array}$ \\
\hline & Assn. & & wk. in Aug. & ITorse \\
\hline & & Los & & Poultry. \\
\hline & Shenandoah Valley Agl & Inter & $2 \mathrm{~d}$ or $3 \mathrm{~d} w \mathrm{w}$ & General agr. \\
\hline
\end{tabular}

WASHINGTON.

\begin{tabular}{|c|c|c|c|c|}
\hline $\begin{array}{l}\text { Aberdeen, Ho- } \\
\text { quiam, or } \\
\text { Grays Har- } \\
\text { bor. }\end{array}$ & Chehalis Co. Fair Assn ........ . & County...... & Oct....... & Genesal agr. \\
\hline Aberdeen..... & $\begin{array}{l}\text { Grays Harbor Poultry Assn. } \\
\text { (Inc.). }\end{array}$ & Intercounty... & Dec............ & Poultry. \\
\hline $\begin{array}{l}\text { Bellingham .... } \\
\text { Clarkston ...... }\end{array}$ & $\begin{array}{l}\text { Bellingham Poultry Assn.... } \\
\text { Asotin Co. Poultry Assn.... }\end{array}$ & County. & Dec. or Jan. & $\begin{array}{l}\text { Do. } \\
\text { Do. }\end{array}$ \\
\hline $\begin{array}{r}\text { Colfax } \\
\text { Do........ }\end{array}$ & $\begin{array}{l}\text { Colfax Poultry } \Lambda \text { ssn. . . . . . . } \\
\text { Whitman Co. Fair } \Lambda \text { ssn..... }\end{array}$ & & Sept or Oct... & $\begin{array}{l}\text { Du. } \\
\text { General }\end{array}$ \\
\hline
\end{tabular}

REQUEST.-It is requested that everybody who is able to do so will send to this department corrections of errors in this bulletin and additions to the list of fairs and exhlbitions. 
TABLE 4,- List of fairs and exhibitions devoted to crriculture, live stock, and other related subjects, by States, 1912-Continued.

WASHINGTON-Continued.

\begin{tabular}{|c|c|c|c|c|}
\hline $\begin{array}{l}\text { Place where } \\
\text { held. }\end{array}$ & $\begin{array}{c}\text { Name of fair, exhibition, or } \\
\text { association. }\end{array}$ & Area covered. & $\begin{array}{l}\text { Time when usually } \\
\text { held, or begins, or } \\
\text { range of dates with- } \\
\text { in which it is held. }\end{array}$ & $\begin{array}{l}\text { Kind of } \\
\text { exhibit. }\end{array}$ \\
\hline Colville. & Stevens Co. Producers' Assn.. & County . & $\begin{array}{l}\text { Between Sept. } 25 \text { and } \\
\text { Oct. } 15\end{array}$ & General agr. \\
\hline Davenpor & Lincoln Co. Fair Assn......... . & $\ldots$... do ... & Oct................... & Do. \\
\hline Dayton. & Touchet Valley Agl. Fair Assn. & Intercounty... & Sept. 15 to $30 .$. & Do. \\
\hline Everett. & Snohomish Co. Kennel Club. . & County.. & Apr.... & Dogs. - \\
\hline Do. & $\begin{array}{l}\text { Snohomish Co. Rose and } \\
\text { Dahlia Soc. }\end{array}$ & Intercount $y$ & $\begin{array}{l}\text { Rose show about June } \\
30 \text {; dahlia s h ow } \\
\text { about Sept. } 10 .\end{array}$ & Floriculture. \\
\hline Hoquian & Hoquiam Poultry Assn... & & & oultry. \\
\hline Kennewick.... & Benton Co. Poultry Assn. & Interstate & Dec. or Jar & Do. \\
\hline Mount Vernon. & Skagit Co. Fair Assn........... & County.. & 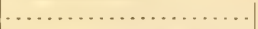 & General agr. \\
\hline North Yakima. & North Yakima Poultry Assn.. & & & Poultry. \\
\hline Do........... & & State... & 3d wk. in Sept........ & General agr. \\
\hline $\begin{array}{l}\text { Olympia........ } \\
\text { Pomeroy....... }\end{array}$ & $\begin{array}{l}\text { Olympia Poultry Assn ........ } \\
\text { Pomeroy Poultry Assn........ }\end{array}$ & Inter & Nov, 15 to Jan. $7 . . . . .$. & $\begin{array}{l}\text { Poultry. } \\
\text { Do. }\end{array}$ \\
\hline Port Townsend. & Jefferson Co. Poultry Assn.... & Intercount & Dee.. & Do. \\
\hline Do & $\begin{array}{l}\text { Olympic Peninsula Fair Assn. } \\
\text { (Inc.). }\end{array}$ & & Sept. or $\mathrm{C}$ & General anr. \\
\hline Puyallup & Valley Fair Assn... & State & 1st wh. in $\mathrm{Oc}$ & Do. \\
\hline Ri & Okanogan Co. Fair Assn..... & Intercounty... & Oet. 1 to $20 .$. & Do. \\
\hline Seattle... & King Co. Fair Assn ........... & County...... & Fall...... & Do. \\
\hline Do. & King Co. Poultry Assn........ & Int & 2d wk. in & Poultry. \\
\hline $\begin{array}{l}\text { Do... } \\
\text { Do... }\end{array}$ & $\begin{array}{l}\text { Seattle Horse Show Assn...... } \\
\text { Seattle Kennel Club. }\end{array}$ & Local.... & Fall.......... & $\begin{array}{l}\text { Horses. } \\
\text { Dogs. }\end{array}$ \\
\hline Snohomis & Snohomish Co. Fair Assn. (Ine.) & Cou & Last part of Sept....... & General agr. \\
\hline Spokane. & $\begin{array}{l}\text { Inland Empire Poultry and } \\
\text { Pet Stock Assn. }\end{array}$ & International. & Jan...... & $\begin{array}{l}\text { Poultry and } \\
\text { pet stock. }\end{array}$ \\
\hline Do & National Apple Show (Inc.)... & National. & Nov & Apples. \\
\hline $\begin{array}{l}\text { Do } \\
\text { Do }\end{array}$ & Spokane Interstate Fair Assn. . & erstat & 1st wk.in Oct. & General agr. \\
\hline Tacoms & $\begin{array}{l}\text { Spokane Kennel Club......... } \\
\text { Pacific Coast Assn. of Nursery- } \\
\text { men. }\end{array}$ & & & $\begin{array}{l}\text { Dogs. } \\
\text { Fruit. }\end{array}$ \\
\hline & Tacoma Kennel Club....... & Local & $\begin{array}{l}\text { From middle to last of } \\
\text { April. }\end{array}$ & Dogs. \\
\hline $\begin{array}{l}\text { Do... } \\
\text { ncouve }\end{array}$ & Tacoma Poultry Assn. (Inc.).. & & 1st wh. in Ja & Poultry. \\
\hline $\begin{array}{l}\text { ancouve } \\
\text { Do... }\end{array}$ & Clark Co. Fair Assn. & Intercou & Sept. or Oc & General agr. \\
\hline Do & Clark Co. Poultry Assu. & International. & Dec. & Poultry. \\
\hline lla Wa & $\begin{array}{l}\text { Walts burg Horse Show Assn.. } \\
\text { Walla WValla Co. Fair Assn. }\end{array}$ & Local..... & A bout May 15 to June 1 & Horses. \\
\hline & Walla Walla Poultry Assn.... & Interstate... & $3 \mathrm{~d}$ wh. in Jan... & Poultry. \\
\hline $\begin{array}{l}\text { ervill } \\
\text { ur... }\end{array}$ & Waterville Poultry Assn ... & & & \\
\hline bur.... & Wilbur Fair Assn....... & Local. & Oc & General agr. \\
\hline
\end{tabular}

WEST VIRGINI.1.

\begin{tabular}{|c|c|c|c|c|}
\hline Belington and & Barbour Co. Poultry Assn.... & State.. & 1st or $2 \mathrm{~d}$ wk. in Jan... & Poultry. \\
\hline Buckhannon.. & Upshur Co. Fair and Agl. & Intercounty... & 1st to $3 \mathrm{~d}$ wk. in Sept... & General agr. \\
\hline Do & $\begin{array}{l}\text { Assn. } \\
\text { Upshur Co. Poultry Assn. }\end{array}$ & Cour & $\begin{array}{l}\text { Between Dec. i and } \\
\text { Mareh } 1 \text {. }\end{array}$ & Poultry. \\
\hline Charles & Charleston Fanciers' Club. & Interstat & $2 \mathrm{~d}$ or $3 \mathrm{~d}$ wk. in Jan.... & Do. \\
\hline & $\begin{array}{l}\text { Kanawha Matinee Driving } \\
\text { Club. }\end{array}$ & do & July 3 to $5 \ldots . . .$. & Horses. \\
\hline Clarksburg & West Virginia Fair Assn...... & Count & $\begin{array}{l}\text { Last of Sept. or early } \\
\text { in Oct. }\end{array}$ & General agr. \\
\hline & EI] & & Sept................. & * \\
\hline & Grove Fair Assn......... & & $\cdots$ & D \\
\hline $\mathrm{E}$ & $\begin{array}{l}\text { Jackson Co, Farmers and } \\
\text { Mechanics' Assn. }\end{array}$ & $\mathrm{Co}$ & & $\pi$ \\
\hline Fail & Fairmount Fair Assn ......... & Intercull & Ahout wh. of Sep & Do. \\
\hline & In & & $2 \mathrm{~d}$ & eral agr. \\
\hline & Valley Poultry Assn. & N: & Thanksgiving wk..... & $\mathrm{Po}$ \\
\hline II & Berkeley Co. Hort. Soc........ & Co & 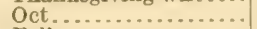 & Horticulture. \\
\hline Do & $\begin{array}{l}\text { Berkeley Co. Poultry and Pet } \\
\text { Stock Assn. }\end{array}$ & Interstate & Fal & $\begin{array}{l}\text { Poultry and } \\
\text { pet stock. }\end{array}$ \\
\hline
\end{tabular}

REQUEST.-It is requested that everyboly who is able to do so will send to this department corrections of errors in this bulletin and additions to the list of fairs and exhibitions. 
TABLE 4.-List of fairs and exhibitions devoted to arriculture, live stock, and other related subjects, by States, 1912-Continued.

WEST VIRGINIA-Continued.

\begin{tabular}{|c|c|c|c|c|}
\hline $\begin{array}{l}\text { Place where } \\
\text { held. }\end{array}$ & $\begin{array}{c}\text { Name of fair, exhibition, or } \\
\text { association. }\end{array}$ & Area covered. & $\begin{array}{l}\text { Time when usually } \\
\text { held, or begins, or } \\
\text { range of dates with- } \\
\text { in which it is held. }\end{array}$ & $\begin{array}{l}\text { Kind of } \\
\text { exhibit. }\end{array}$ \\
\hline Middlebourne.. & Tyler Co. Fair Assn... & County.. & Last of Aug. or early & General agr. \\
\hline Morgantowr & Monongalia-Preston Fair Assn. & Intercounty & $\begin{array}{l}\text { in sept. } \\
\text { Aug. } 25 \text { to Sept. } 25 . . .\end{array}$ & Do. \\
\hline Do... & Morgantown Poultry Assn .... & & & Poultry. \\
\hline Parkersburg.... & $\begin{array}{l}\text { Parkersburg Fanciers' Club } \\
\text { (Inc.). }\end{array}$ & National.. & $\begin{array}{l}\text { Last of Dec. or early } \\
\text { in Jan. }\end{array}$ & Do. \\
\hline Pennsboro. & Ritchie Co. Agl. and Fair Assn. & County. & Last of Aug. or early & General agr. \\
\hline $\begin{array}{l}\text { Philippi a n d } \\
\text { Belington. }\end{array}$ & Barbour Co. Poultry Assn.... & State.... & 1st or $2 \mathrm{~d}$ wk. in Jan... & Poultry. \\
\hline $\begin{array}{l}\text { Ripley .......... } \\
\text { Salem........ }\end{array}$ & Ripley Racing and Stock Assn. & Intercounty... & Week of Sept. 12 . & Live stock. \\
\hline Shepherdstown & 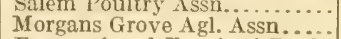 & Intercoun & 1st wk. in & $\begin{array}{l}\text { Poultry. } \\
\text { General agr. }\end{array}$ \\
\hline St. Marys...... & $\begin{array}{l}\text { Farmers' and Fanciers' Poul- } \\
\text { try Assn. }\end{array}$ & Interstate..... & $\begin{array}{l}\text { Last of Dec. or early in } \\
\text { Jan. }\end{array}$ & $\begin{array}{l}\text { Poultry. } \\
\text { Pour. }\end{array}$ \\
\hline Walton. & Roane Co. Fair Assn .... & County. & & General agr. \\
\hline $\begin{array}{l}\text { TI eston. } \\
\text { Wheeling }\end{array}$ & Lewis Co. Fair Assn... & .... do... & Sept. . & 1)o. \\
\hline Wheeling. & Tri-State Poultry Assn ....... & Interstate & $2 \mathrm{~d}$ or $3 \mathrm{~d}$ wk. in Jan... & Poultry. \\
\hline Do & $\begin{array}{l}\text { West Virginia Expo. aud State } \\
\text { Fair Assn. }\end{array}$ & ...... do... & 1st or $2 \mathrm{~d}$ wk. in Sept.. & General agr. \\
\hline $\begin{array}{r}\text { Do.......... } \\
\text { Williamstown.. }\end{array}$ & $\begin{array}{l}\text { West Virginia State Fair Assn. } \\
\text { Williamstown Poultry Assn... }\end{array}$ & State.. & From Sept. 1 to $15 . .$. & $\begin{array}{l}\text { Do. } \\
\text { Poultry. }\end{array}$ \\
\hline
\end{tabular}

WISCONSIN.

\begin{tabular}{|c|c|c|c|c|}
\hline & Albany Poultry Assn & & & Poultry. \\
\hline her & Portage Co. Fair Assn. & & & General as \\
\hline$\Lambda$ & Langlade Co. Agl. Soc......... & County......... & Between Sept. 15 and & Do. \\
\hline Appleton & Fox River Fair Assn. & Intercounty... & $3 \mathrm{~d}$ or 4 th wk. in Sept. & Do. \\
\hline & Ashland Co. Agl. Soc... & County....... & $2 \mathrm{~d}$ wh. in Sept.. & Do. \\
\hline & Eau Claire Co. Agl. Soc....... & ..... do......... & Last of Sept. or early & Do. \\
\hline $\mathrm{Ba}$ & Sauk Co. Agl. Soc. & State. & Sept. 20 to Oct. 1..... & Do. \\
\hline $\mathrm{Be}$ & $\begin{array}{l}\text { Beaver Dam Poultry Assn. } \\
\text { (Inc.). }\end{array}$ & International. & $2 \mathrm{~d} w \mathrm{k}$, in Dec... & Poultry. \\
\hline 1 & Dodge Co. Fair Assn .......... & State. & Last Mon. in Sept..... & General agr. \\
\hline Beloi & Beloit Poultry Assn..... & Mnto & $\cdots \cdots$ & Poultry. \\
\hline & Green Lake Co. $A$ gl. Soc...... & anty... & $3 \mathrm{~d} v$ & General agr. \\
\hline is & $\begin{array}{l}\text { Jackson Co. Agl. Soc ......... } \\
\text { Blakes Prairie Agl. Assn.... }\end{array}$ & $\begin{array}{l}\text { County. } \\
\text { Local. }\end{array}$ & About ist & $\begin{array}{l}\text { Do. } \\
\text { Do. }\end{array}$ \\
\hline B & $\begin{array}{l}\text { Boscobel Agl. and Driving } \\
\text { Park Assn. }\end{array}$ & ..... do & $2 \mathrm{~d}$ wk, in Aug... & Do. \\
\hline & Rusk Co. Fair Assn ........... & Intercounty... & About middle of Sept. & Do. \\
\hline - & Cambridge Poultry Assn...... & & $\because 3$ & Poultry. \\
\hline 1 & kee Co. Agl. Soc......... & Cour & $3 \mathrm{~d}$ or 4 th wh & General agr. \\
\hline Chippewa Falls & Northern Wisconsin State & State. & $\begin{array}{l}\text { 1st wk. in Sept.. } \\
3 d \mathrm{l} \text {, in Sept.. }\end{array}$ & $\begin{array}{l}\text { Do. } \\
\text { Do. }\end{array}$ \\
\hline C & Forest Co. Agl. Assn... & $\mathrm{Co}$ & Ser & Do. \\
\hline & $\begin{array}{l}\text { Southeastern Wisconsin Poul- } \\
\text { try Assn. }\end{array}$ & Local. & Dec. or Jan & Poultry. \\
\hline .. & Lafayette Co. Agl. Soc......... & Coun & Last full wh & General agr. \\
\hline $\mathrm{E}$ & Brown Co. Agl. and Fair Assn. & do......... & Last wk. in Aug. & Do. \\
\hline 80 & $\begin{array}{l}\text { Southwestern Wisconsin Poul- } \\
\text { try Assn. }\end{array}$ & Intercounty... & 1st part of Jan... & Poultry. \\
\hline & Dowing Free Agl. Assn ....... & Local .... & Between Oct. 1 and 15. & General agr. \\
\hline 1010. & Walworth Co, Agl, Soc.. & International... & Wk, following State & Do. \\
\hline Ellsworth & $\begin{array}{l}\text { Pierce Co. Central Fair and } \\
\text { Stock Expo. }\end{array}$ & $\mathrm{Cc}$ & $3 \mathrm{~d}$ or 4 th wk. in Sept.. & Do. \\
\hline Eir & Elroy Fair Assn... & & & D \\
\hline $\begin{array}{ll}\mathrm{E} \\
\mathrm{F}\end{array}$ & Evansville Rock Co. Agl. Assn. & State. & B. $\Lambda$ & $\mathrm{D}$ \\
\hline $\begin{array}{l}\text { Fennimore..... } \\
\text { Fond du Lae... }\end{array}$ & $\begin{array}{l}\text { Grant Co. Fair Assn ........... } \\
\text { Fond du Lac Co. Agl. Soc..... }\end{array}$ & County... & A bout $\Lambda$ ug. 27 to 30. & $\mathrm{D}$ \\
\hline $\mathrm{D}$ & Fond du Lac Poultry Assn.... & & & Poultry. \\
\hline endshin & Adams Co. Agl. Soc.... & County... & $3 d$ wk. in Sept & General agr. \\
\hline $\begin{array}{l}\text { Athins } \\
\text { ville. }\end{array}$ & Fort Atkinson Poultry Assn.. & ..... do....... & About Dec, 11 to $16 \ldots$ & Poultry. \\
\hline esville.... & Trempealeau Co. Agl. Soc & Intercounty. & Last half of Aug & General agr. \\
\hline
\end{tabular}

REQUEST. It is requested that everybody who is able to do so will send to this department corrections of errors in this bulletin and additions to the list of fairs and exhibitions. 
TABLE 4.-List of fairs and exhibitions devoted to agriculture, live stock, and other related subjects, by States, 1912 -Continued.

WISCONSIN-Continned.

\begin{tabular}{|c|c|c|c|c|}
\hline $\begin{array}{l}\text { Place where } \\
\text { held. }\end{array}$ & $\begin{array}{l}\text { Name of fair, exhibition, or } \\
\text { association. }\end{array}$ & Area covered. & $\begin{array}{l}\text { Time when usually } \\
\text { held, or begins, or } \\
\text { range of dates with- } \\
\text { in which it is held. }\end{array}$ & $\begin{array}{l}\text { Kind of } \\
\text { exhibit. }\end{array}$ \\
\hline Glenwood City. & $\begin{array}{l}\text { Glenwood Intercounty Fair } \\
\text { Assn. }\end{array}$ & Intercounty... & A bout Sept. 25 to $27 \ldots$ & General agr. \\
\hline Grantsbur & Burnett Co. Agl. Soc........... & County... & Last 3 days in Sept.... & Do. \\
\hline Gray Mills & $\begin{array}{l}\text { Central Agl. and Driving Park } \\
\text { Assn. }\end{array}$ & (n......... & 1st $w \mathrm{k}$. in Oet........... & Do. \\
\hline Green Bay & $\begin{array}{l}\text { Northeastern Poultry and Pet } \\
\text { Stock Assn. }\end{array}$ & Local. & Jan, or Feh.... & $\begin{array}{l}\text { Poultry and } \\
\text { pet stock. }\end{array}$ \\
\hline Haywar & Sawyer Co. Agl. Fair Assn.... & County. & 1st wk. in Oet. & General agr. \\
\hline Hillsbor & $\begin{array}{l}\text { Hillsboro Agl. and Driving } \\
\text { Assn. }\end{array}$ & Intercour & A bout middle of Aug.- & Do. \\
\hline Hortonvi & Outagamie Co. Agl. Soc....... & Loca & Sept. & Do. \\
\hline $\begin{array}{l}\text { Iron Riv } \\
\text { Janesvill }\end{array}$ & Bayfield Co. Fair Assn.... & Count & Last 10 days of Sept... & $\begin{array}{l}\text { Do. } \\
\text { Poultry }\end{array}$ \\
\hline $\begin{array}{l}\text { Janesville } \\
\text { Jefferson. }\end{array}$ & $\begin{array}{l}\text { Janesville Poultry Assn ....... } \\
\text { Jefferson Co. and Rock River } \\
\text { Valley Agl. Soc. }\end{array}$ & 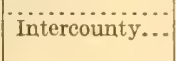 & ist wk. in Sept. & $\begin{array}{l}\text { Poultry. } \\
\text { General agr. }\end{array}$ \\
\hline Kilbour & Kilbourne Intercounty Fair... & $\ldots . . \mathrm{dc}$ & About Oct. 1 .. & Do. \\
\hline Knap & Knapp Fair Assi & & Sept. 20. & Do. \\
\hline $\begin{array}{l}\text { La Cross } \\
\text { Do.. }\end{array}$ & $\begin{array}{l}\text { La Crosse Interstate Fair Assn. } \\
\text { La Crosse Kennel Club. . . . . . . }\end{array}$ & $\begin{array}{l}\text { Interst: } \\
\text {..... do }\end{array}$ & About Sept. 23 .. & Do. \\
\hline Do.. & $\begin{array}{l}\text { Western Wisconsin Poultry } \\
\text { Assn. }\end{array}$ & & 1st or $2 \mathrm{~d}$ wh. in Dec... & Poultry. \\
\hline Lake Gen & Lake Geneva Poultry Assn.... & & & Do. \\
\hline $\begin{array}{l}\text { Lancaste } \\
\text { Lodi... }\end{array}$ & Grant Co. Agl. Soc .............. & & A bout Sept. 18 to $20 \ldots$ & General agr. \\
\hline & 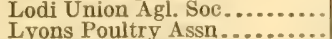 & Lo & A bout Aug. $20 \ldots \ldots .$. & $D$ \\
\hline Madisor & $\begin{array}{l}\text { Lyons Poultry Assn....... } \\
\text { Dane Co. Agl. Soc......... }\end{array}$ & $\because \mathrm{Coi}$ & $\Lambda$ bout middle of Sept... & $\begin{array}{l}\text { Poultry. } \\
\text { General agr. }\end{array}$ \\
\hline Do. & Wisconsin Poultry Assn...... & Stat & $2 \mathrm{~d} w \mathrm{k}$. in Jan......... & Poultry. \\
\hline Do. & Wisconsin State Hort. Soc.... & $\ldots$ & ....do............ & Horticulture. \\
\hline $\begin{array}{l}\text { Manitow } \\
\text { Do... }\end{array}$ & $\begin{array}{l}\text { Manitowoc Co. Fair Assn ..... } \\
\text { Manitowoc Feathered Stock }\end{array}$ & Cou & $\begin{array}{l}\text { Last part of Aug....... } \\
\text { Thanksgiving wk..... }\end{array}$ & $\begin{array}{l}\text { General agr. } \\
\text { Poultry. }\end{array}$ \\
\hline & Assn. & & & \\
\hline Marshf & Central Wisconsin State Fair & Interstate... & 3d wk. in Aug.......... & General agr. \\
\hline $\begin{array}{l}\text { Maustor } \\
\text { Medford }\end{array}$ & Juneau Co. Agl. Soc. ........... & Inte & 1st wk. in Sept... & Do. \\
\hline Menomo & $\begin{array}{l}\text { Taylor Co. Agl. and Mechl. } \\
\text { Assn. }\end{array}$ & coun & A bout sept. Ir to & 00. \\
\hline $\begin{array}{l}\text { Menomc } \\
\text { Do. }\end{array}$ & $\begin{array}{l}\text { Dunn Co. Agl. Soc............. } \\
\text { Northwestern Wisconsin State }\end{array}$ & & $2 d$ wk. in Sept. & Do. \\
\hline Ler & Poultry Assn. & & & Poultry. \\
\hline Ler & Lincoln Co. Agl. Soc ........... & Count & Last wk. in Aug.. & General agr. \\
\hline Do. & $\begin{array}{l}\text { Milwaukee Florists' Club...... } \\
\text { Milwaukee Poultry Assn..... }\end{array}$ & & Nov.. & $\begin{array}{l}\text { Floriculture. } \\
\text { Poultry. }\end{array}$ \\
\hline & Milwaukee Riding Club... & $\mathrm{Lc}$ & De & Horses. \\
\hline$D$ & National Dairy Show Assn.... & Internat & Oct. $22 \mathrm{t}$ & $\begin{array}{l}\text { Dairy prod. } \\
\text { ucts. }\end{array}$ \\
\hline Do & $\begin{array}{l}\text { Wisconsin Cheese Makers' } \\
\text { Assn. }\end{array}$ & Stat & Jan & Do. \\
\hline $\begin{array}{l}\text { Do. } \\
\text { Mineral }\end{array}$ & Wisconsin State Board of Agr & $d($ & $2 \mathrm{~d}$ full wk & General agr. \\
\hline Do. & $\begin{array}{l}\text { Mineral Point Poultry Assn... } \\
\text { Southwestern Wisconsin Fair. }\end{array}$ & & $\begin{array}{l}2 \mathrm{~d} \text { wh. in Jan ... } \\
\text { About middle of }\end{array}$ & $\begin{array}{l}\text { Poultry. } \\
\text { General agr. }\end{array}$ \\
\hline $\begin{array}{l}\text { Mondov } \\
\text { Monroe. }\end{array}$ & Buffalo Co. AgI. Assn .......... & ..... do. & A & Do. \\
\hline Montfol & $\begin{array}{l}\text { Green Co. Agl. Soc. and } \\
\text { Mechl. Inst. }\end{array}$ & do & $2 \mathrm{~d}$ or $3 \mathrm{~d} \mathrm{wk}$. in Sept... & Do. \\
\hline Montfor & Montfort Poultry Assn.. & & $\begin{array}{l}\text { 1st wk. in J } \\
\text { Sept. . . . }\end{array}$ & Poultry. \\
\hline New London.... & New London Agl. and Indus- & Intercou & 1st wk. in Oct... & $\begin{array}{l}\text { Generai agr. } \\
\text { Do. }\end{array}$ \\
\hline $\mathrm{Ne}$ & New Richmond Park Assn.... & Lo & & \\
\hline Ocono & $\begin{array}{l}\text { Oconomowoc Poultry and Pet } \\
\text { Stock Assn. }\end{array}$ & Natior & Begins $2 \mathrm{~d}$ Wed.in Dec. & $\begin{array}{l}\text { Poultry and } \\
\text { pet stock. }\end{array}$ \\
\hline Ocont & Oconto Co. Fair Assn. & Int & 1st wk. in Sept. & Géneral agr. \\
\hline Oshkos & $\begin{array}{l}\text { Oshkosh Poultry Assn. } \\
\text { Winnebago Co. Fair As }\end{array}$ & & & $\begin{array}{l}\text { Poultry. } \\
\text { Generalagr. }\end{array}$ \\
\hline Philli & $\begin{array}{l}\text { Winnebago Co. Faur Assu } \\
\text { Price Co.Agl. Soc........ }\end{array}$ & & Last wk. in Sept...... & Do. \\
\hline Pl & Mound City Poultry Ass & Local. & $\begin{array}{l}\text { Last wk. in Dec. or 1st } \\
\text { wk. in Jan. }\end{array}$ & Poultry. \\
\hline $\begin{array}{l}\text { Do. } \\
\text { Plymout }\end{array}$ & $\begin{array}{l}\text { Platteville Fair Assn... } \\
\text { Eastern WVisconsin }\end{array}$ & International & $\begin{array}{l}\text { About 1st wh in Sept.. } \\
\text { Dec. and Jan.......... }\end{array}$ & $\begin{array}{l}\text { General agr. } \\
\text { Poultry. }\end{array}$ \\
\hline & $\begin{array}{l}\text { and Pet Stock Assn. } \\
\text { Sheboygan Co. Agl. Assn..... }\end{array}$ & & Sept. & Generala \\
\hline $\mathrm{R}$ & Sheboygan Co. Agl Assn....... & $\ldots$. do & Last wk. in Aug. & 1 o. \\
\hline Bopin & $\begin{array}{l}\text { Racine Feathered and Pet } \\
\text { Stock Assn. (inc.). }\end{array}$ & National. & $2 d$ or $3 d$ wk. in Jan.... & $\begin{array}{l}\text { Poultry and } \\
\text { pet stock. }\end{array}$ \\
\hline
\end{tabular}

REOUEST - It is requested that everybody who is able to do so will send to this department corrections of errors in this bulletin and additions to the list of fairs and exhibitions. 
TABLE 4.-List of fairs and exhibitions devoted to agriculture, live stock, and other related subjects, by States, 1912-Continued.

WISCONSIN-Continued.

\begin{tabular}{|c|c|c|c|c|}
\hline $\begin{array}{l}\text { Place where } \\
\text { held. }\end{array}$ & $\begin{array}{c}\text { Name of fair, exhibition, or } \\
\text { association. }\end{array}$ & Area covered. & $\begin{array}{l}\text { Time when usually } \\
\text { held, or begins, or } \\
\text { range of dates with- } \\
\text { in which it is held. }\end{array}$ & $\begin{array}{l}\text { Kind of } \\
\text { exhibit. }\end{array}$ \\
\hline Reedsbur & Baraboo Valley Agl. Soc.. & Intercounty.. & Early in Aug. & General agr. \\
\hline 1) $0 . .$. & Reedsburg Poultry Assn....... & 2. & 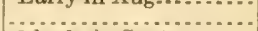 & Poultry. \\
\hline Rhinelander... & Oneida Co. Agl. Soc.......... & County. & $2 \mathrm{~d}$ wk. in Sept & Generalagr. \\
\hline Rice Lake...... & Barron Co. Agl. Soc... & .....do... & .... do............ & Do. \\
\hline $\begin{array}{l}\mathrm{R} \text { ic hl a } \mathrm{nd} \\
\text { Center. }\end{array}$ & Richland Co. Agl. Soc......... & ..... do... & Last wk. in Sept & Do. \\
\hline Seneca......... & Crawford Co. Agl. Assn. & do. & Sept & Do. \\
\hline Seymour. . & $\begin{array}{l}\text { Seymour Fair and Driving } \\
\text { Park Assn. }\end{array}$ & Intercount & $\ldots . . . d$ & Do. \\
\hline Shawano. & Shawano Co. Agl. Soc........ & County.... & ....do. do. & Do. \\
\hline $\begin{array}{l}\text { Sheboygat } \\
\text { Sparta... }\end{array}$ & $\begin{array}{l}\text { West Shore Fanciers' Assn .... } \\
\text { Sparta Poultry Assn. }\end{array}$ & Local... & Dec. and Jar & Poultry. \\
\hline Spring Gree & 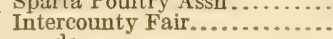 & Intercounty... & Aug. 20 to Sept. ic & General agr. \\
\hline Stanley ... & .....do............... & ......do.... & Last wk. in Sept. & Do. \\
\hline Stevens Poi & Stevens Point Fair Assn ...... & County... & About Sept. 10. & Do. \\
\hline St. Croix F & Polk Co. Fair Soc................ & .....do. do. & $\begin{array}{l}3 \mathrm{~d} \text { or } 4 \text { th wh. in Sept. } \\
\text { or early in Oct. }\end{array}$ & Do. \\
\hline $\begin{array}{l}\text { Stoughton..... } \\
\text { Sturgeon Bay.. }\end{array}$ & $\begin{array}{l}\text { Stoughton Poultry Assn . . . . . . . } \\
\text { Door Co. Fair Assn............. }\end{array}$ & Col & About Sept. & $\begin{array}{l}\text { Poultry. } \\
\text { General agr. }\end{array}$ \\
\hline Superior.. & Superior Poultry Assn ........ & & & Poultry. \\
\hline Tomah. & Eastern Monroe Co. Agl. Soc.. & Intercount & Sept. or Oct & General agr. \\
\hline Viola. & $\begin{array}{l}\text { Kickapoo Valley Agl. and } \\
\text { Driving Park Ássn. }\end{array}$ & ..... do.... & ..... do....... & Do. \\
\hline $\begin{array}{l}\text { Viroq } \\
\text { IVate }\end{array}$ & Vernon Co. Agl. Soc............ & County.... & About middle of Sept. & Do. \\
\hline $\begin{array}{l}\text { Waterford.. } \\
\text { Watertown. }\end{array}$ & $\begin{array}{l}\text { Waterford Poultry Assn........ } \\
\text { Watertown Intercounty Fair }\end{array}$ & Interstate..... & 1st wk. in Feb. & Poultry. \\
\hline & Asssn. & & & als \\
\hline Wanto & Waushara Co. Agl.Soc.. & County & Last wk. in Ser & $\begin{array}{l}\text { Poultry. } \\
\text { General agr. }\end{array}$ \\
\hline Waukesha & Waukesha Poultry Assn...... & ... & & Poultry. \\
\hline Waupaca. & Waupaca Poultry Assn ........ & & & Do. \\
\hline Wausau... & Central Wisconsin Poultry & Stc & Last wk. in Jar & Do. \\
\hline Do.... & Marathon Co. Agl. Soc.... & County......... & 1st wk. in Sept........ & General agr. \\
\hline West Beno & Washington Co. Agl. Soc... & Intercounty... & $\begin{array}{l}\text { Wk. following Wis. } \\
\text { State Fair. }\end{array}$ & \\
\hline Westfield & Marquette Co. Agl, Soc... & County.. & Last part of Sept...... & Do. \\
\hline West Salem. - & La Crosse Co. Fair Assn...... . . & ..... do... & . & Do. \\
\hline $\begin{array}{l}\text { Weyauwega.. } \\
\text { Wittenberg.. }\end{array}$ & $\begin{array}{l}\text { Waupaca Co. Agl. Assn ....... } \\
\text { Badger Poultry and Pet Stock }\end{array}$ & Interstate............ & 3d wk in sept.... & $\begin{aligned} & \text { Do. } \\
& \text { Poultry }\end{aligned}$ \\
\hline & Assn. & & & pet stock. \\
\hline
\end{tabular}

WYOMING.

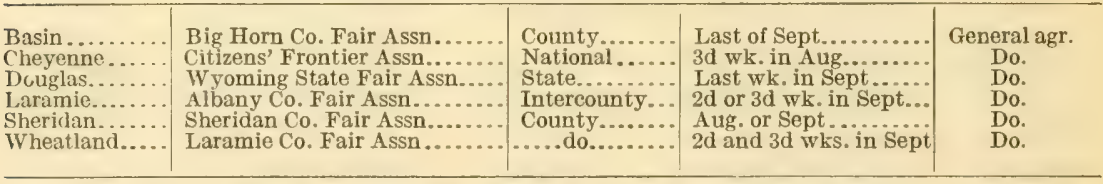

REQUEST.-It is requested that everybody who is able to do so will send to this department corrections of errors in this bulletin and additions to the list of fairs and exhibitions. 


, 

LIBRARY OF CONGRESS

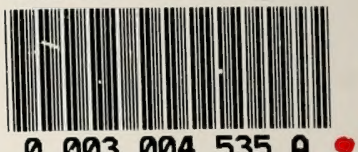

0003004535 A 